\title{
The apple snail, Pomacea canaliculata: an evidence note on invasiveness and potential economic impacts for East Africa
}

\section{Authors}

Djamila Djeddour Corin Pratt

Fernadis Makale Ivan Rwomushana

May 2021 Roger Day

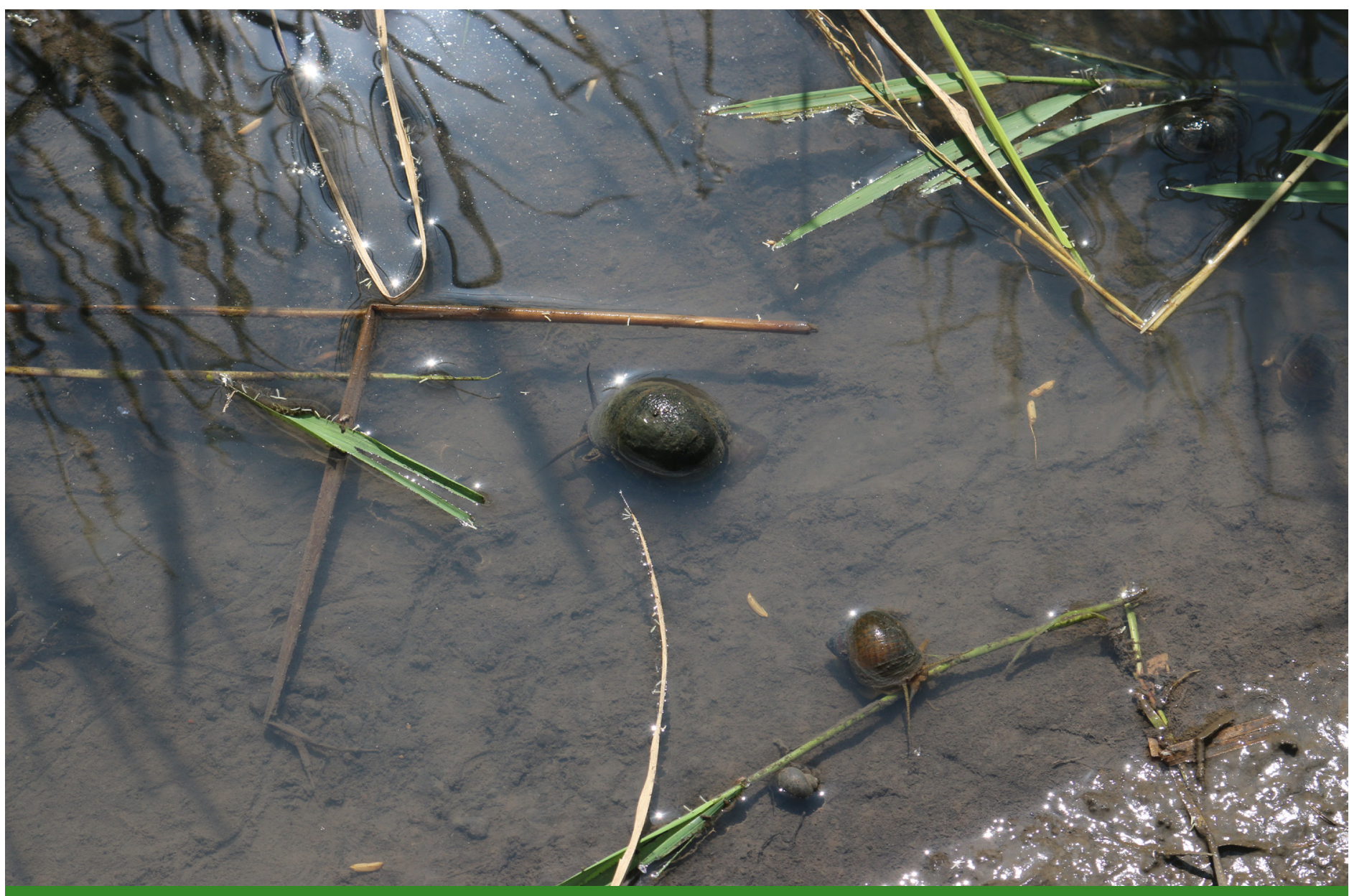

KNOWLEDGE FOR LIFE 


\section{(c) $(1) \Theta$}

The copyright holder of this work is $\mathrm{CAB}$ International (trading as $\mathrm{CABI}$ ). It is made available under a Creative Commons Attribution-Non-commercial Licence (CC BY-NC). For further details please refer to http://creativecommons.org/license.

This paper was prepared as part of the Action on Invasives and Plantwise Plus programmes. Action on Invasives is supported by the UK Foreign, Commonwealth and Development Office (FCDO) and the Netherlands Directorate General for International Cooperation (DGIS). Plantwise Plus, in addition to FCDO and DGIS, is also funded by European Commission Directorate-General for International Cooperation and Development (DEVCO) and Swiss Agency for Development and Cooperation (SDC). We thank the survey respondents, including those whose partial responses have been quoted with their permission.

$C A B I$ is an international intergovernmental organization, and we gratefully acknowledge the core financial support from our member countries (and lead agencies) including the UK (FCDO), China (Chinese Ministry of Agriculture and Rural Affairs), Australia (Australian Centre for International Agricultural Research), Canada (Agriculture and Agri-Food Canada), the Netherlands (DGIS) and Switzerland (Swiss Agency for Development and Cooperation). See http://www.cabi.org/about-cabi/who-we-work-with/key-donors/ for full details.

This CABI Working Paper was internally and externally peer-reviewed. It may be referred to as:

Djeddour, D., Pratt, C., Makale, F., Rwomushana, I. and Day, R. (2021) The apple snail, Pomacea canaliculata: an evidence note on invasiveness and potential economic impacts for East Africa. CABI Working Paper 21, 77 pp. https://dx.doi.org/10.1079/CABICOMM-62-8149

Djamila Djeddour, CABI UK, Bakeham Lane, Egham, Surrey, TW20 9TY, United Kingdom. Email: d.djeddour@cabi.org; ORCID: https://orcid.org/0000-0002-1421-4101

Corin Pratt, CABI, CABI UK, Bakeham Lane, Egham, Surrey, TW20 9TY, United Kingdom. Email: c.pratt@cabi.org; ORCID: https://orcid.org/0000-0001-8070-7302

Fernadis Makale, CABI, Canary Bird, 673 Limuru Road, Muthaiga, PO Box 633-00621, Nairobi, Kenya. Email: f.makale@cabi.org; ORCID: https://orcid.org/0000-0002-6454-7705 Ivan Rwomushana, CABI, Canary Bird, 673 Limuru Road, Muthaiga, PO Box 633-00621, Nairobi, Kenya. Email: I.Rwomushana@cabi.org; ORCID: https://orcid.org/0000-0001-5840$\underline{8058}$

Roger Day, CABI, Canary Bird, Muthaiga, PO Box 633-00621 Nairobi, Kenya. Email: r.day@cabi.org; ORCID: https://orcid.org/0000-0002-4854-7609

Cover photo: Pomacea canaliculata feeding on rice plants, Mwea Irrigation Scheme, Kenya. Credit: Fernadis Makale, CABI. 


\section{Contents}

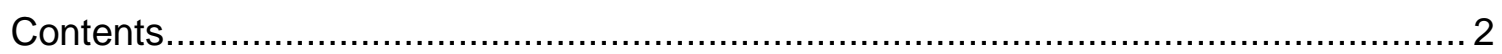

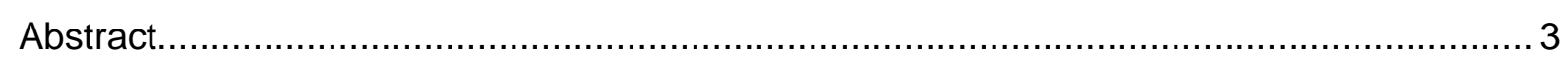

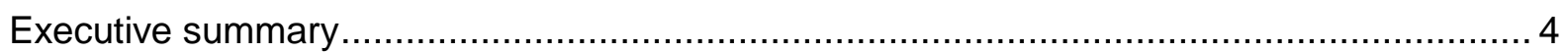

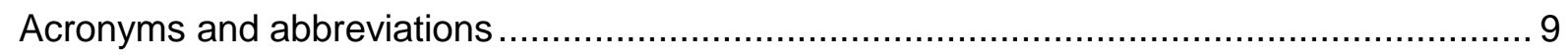

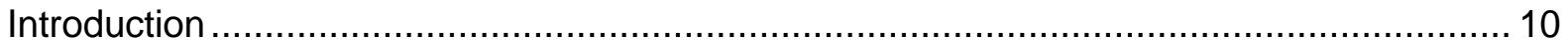

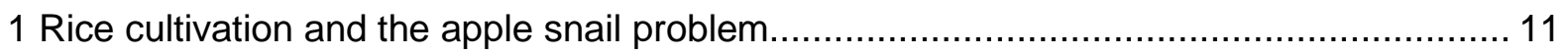

1.1 History of rice production and trends in Africa ............................................ 11

1.2 Biology and identification of invasive Pomacea species .................................... 14

1.3 Invasive apple snail spread around the world .................................................. 16

1.4 Invasive apple snail host range and general impacts ........................................ 18

1.5 Invasive apple snail impact on human health ...................................................... 20

1.6 Current spread and distribution of invasive apple snail in Africa .......................... 21

1.7 Modelling the distribution of invasive apple snail ............................................. 23

1.8 Environmental suitability for invasive apple snail colonization............................. 25

2 Impacts of apple snail on rice and other socio-economic variables ................................ 26

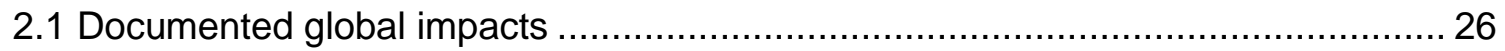

2.2 Prediction of economic and yield loss due to invasive apple snail in East Africa.... 28

2.3 Potential impacts of invasive apple snail on trade............................................ 33

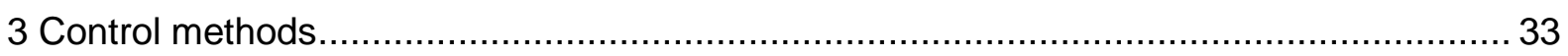

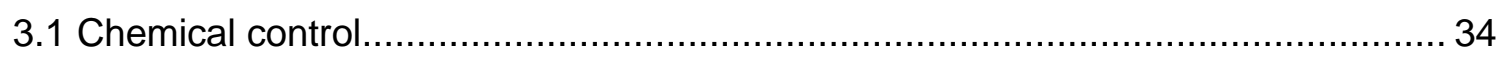

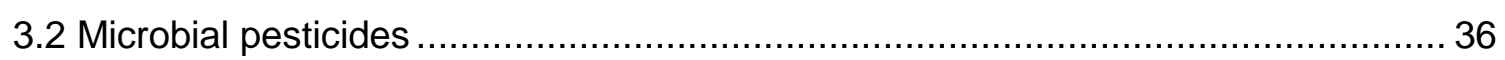

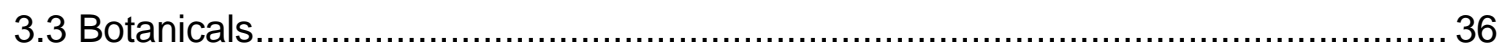

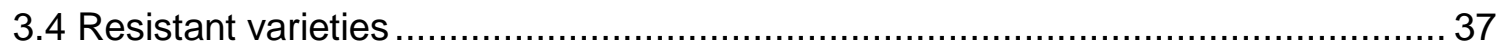

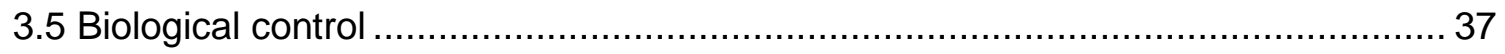

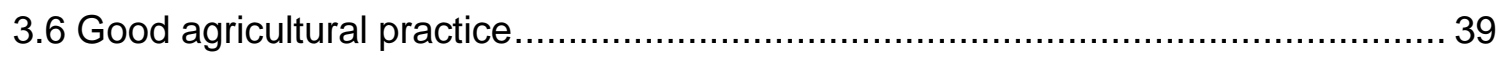

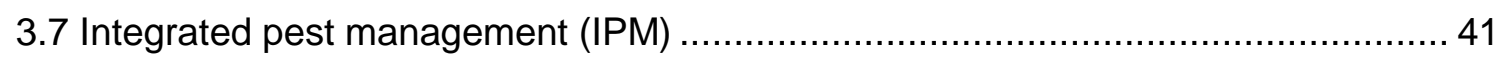

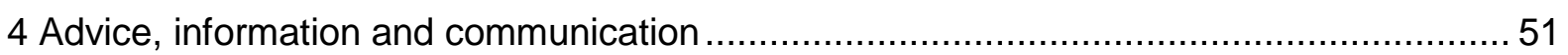

4.1 Sources of information on apple snail control ................................................ 51

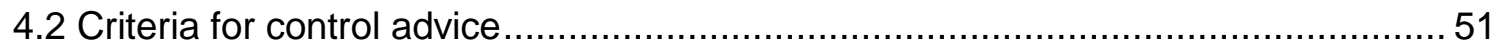

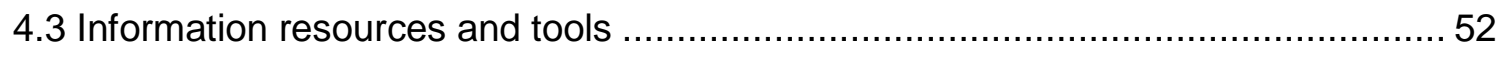

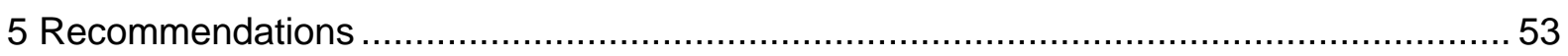

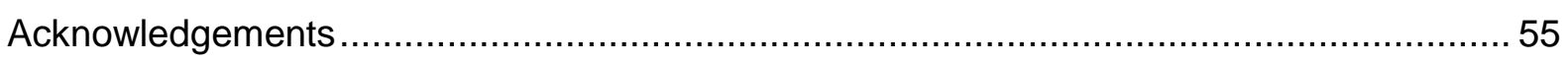

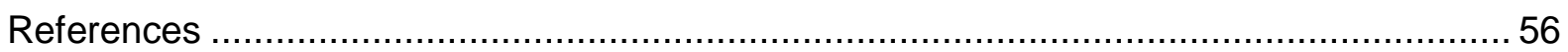




\section{Abstract}

The South American freshwater apple snail, Pomacea canaliculata (Lamarck) has been introduced and become invasive in many parts of the world, causing significant economic losses in wetland rice cultivation, threatening biodiversity and impacting on human health. The confirmed report in $\mathbf{2 0 2 0}$ of this snail species damaging rice crops in Mwea, the most important irrigation scheme in Kenya, represents a new introduction to continental Africa and brings into focus the need for a rapid and coordinated response to contain and mitigate the risk to other rice schemes, as well as neighbouring countries. This evidence note provides a review of the global invasive spread of $P$. canaliculata, its biology and ecological adaptability and assesses the risks and potential economic/yield losses for sub-Saharan African rice production over the next decade under different control scenarios. Given the strategic importance of rice production in the region, the potential impacts on food security and farmer income could be considerable. Monitoring, sustainable management and good agricultural practice recommendations are synthesized from established global resources and information is collated to support preparatory action and rapid response. Given the relatively localized distribution of the snail in Kenya, the implementation of a coordinated snail containment and eradication plan is urgently called for, underpinned by countrywide awareness raising, education and outreach to facilitate community-based vigilance and management. 


\section{Executive summary}

\section{Background}

Invasive apple snails commonly referred to as 'golden apple snails' (GAS), belonging to the genus Pomacea pose major economic, environmental and health problems across many parts of the world. They have been widely introduced, either intentionally, as a human food resource, through the aquarium trade as a domestic snail pet or for aquatic weed control in both natural wetlands and irrigated rice, or accidentally, through water systems and as trade contaminants. Pomacea canaliculata (Lamarck), widely regarded as the most devastating of these pest species, has been identified from Kenyan rice paddies, the first record for mainland Africa. This evidence note provides a summary of knowledge about the invasive apple snail, its impacts and a synthesis of options for management from other affected countries. It is imperative that ecologically and economically sustainable approaches are put into practice for the integrated control of this destructive invasive mollusc species in Kenya, together with the implementation of effective quarantine and contingency measures, to avoid further spread to vulnerable areas of the country and neighbouring rice-growing countries.

\section{Strategic importance of rice}

Rice has been identified as a crucial strategic crop for food security, income generation and nutrition in Kenya. The government has elaborated National Rice Development Strategies to guide and grow the promotion of the rice subsector, focusing on procedures that will enhance rice-production areas in order to achieve self-sufficiency and reduce the need for costly imports. Kenya's policy makers will need to acknowledge and act rapidly to mitigate the potential constraints to enhanced domestic rice production that invasions of $P$. canaliculata could entail.

\section{Invasive apple snail life cycle and crop damage}

Invasive apple snails have a high reproductive output, fast growth rate and an ability to rapidly adapt to ambient conditions, threats from predators and other mortality factors. Combined with a high plasticity in life cycle, these characteristics allow snail populations to survive environmental perturbations and to rapidly build up numbers, with management pressures leading to adaptation and avoidance. Snails are macrophytophagous but feed voraciously and indiscriminately in the absence of their preferred plants. Staple crops such as taro and rice, as well as other aquatic cultivated crops, suffer heavily from their destructive feeding, with young rice seedlings representing the most vulnerable stage. Entire fields can be lost, affecting smallholder farmer livelihoods in particular. Invasive apple snails also negatively impact wetland ecosystem functioning and human health as they are vectors for parasites such as rat lungworm and cause skin irritations.

\section{Distribution and potential spread of invasive apple snail in East Africa}

Invasive apple snails are naturally distributed in tropical and subtropical freshwater ecosystems globally, but the genus Pomacea is endemic to South and Central America. $P$. canaliculata is able to reproduce continuously, reaches maturity sooner, can complete more generations per year and maintain high populations of juvenile and mature snails year-round in tropical regions. Climate modelling of the current and potential geographic range and performance of Pomacea snails in different locations indicates that many of the rice-producing areas of eastern Africa (and SSA more broadly) are likely to be under threat, including all areas of Tanzania, the major producer in the region. Climate change will undoubtedly 
contribute to wider establishment and colonization, with potential 'hot spots' for higher population density. Higher resolution modelling of population dynamics for those areas of Africa which may be at risk would be valuable and would facilitate potential crop loss estimates as well as informing management priorities and biosecurity measures.

\section{Potential economic impacts of invasive apple snail in East Africa}

Invasive apple snails will damage most aquatic crops, including taro, but it is for their impact on rice crops that they have gained notoriety around the world. Examples from Asia indicate that once present, Pomacea can spread rapidly (particularly if facilitated by intentional movement), and entry into waterways and irrigation systems results in widespread infestation of rice paddies. Mwea is the primary rice-growing area in Kenya and in this region alone, $P$. canaliculata has the potential to affect approximately $80 \%$ of Kenya's rice production. Present and near-term losses are likely to be important, as $P$. canaliculata has a foothold and is already affecting production, but without efforts to manage populations and contain the snail's spread, future losses across the region to rice and other host crops could be much greater. Were $P$. canalicula to spread across the region to infest rice in parts of Tanzania, Uganda and Ethiopia in addition to Kenya, annual production losses of US\$122 million could be feasible within a decade of arrival without control measures. Even with control measures, regional losses of US\$67-116 million/year could be possible if the snail is not contained.

\section{Management of invasive apple snail}

The primary management approach for invasive apple snails must be prevention since eradication of established populations is very difficult. Strict quarantine must be enforced to prevent introduction and spread and if detected, snails must be contained and eradicated rapidly while it is still possible to do this. Attempts at management elsewhere include use of pesticides, with serious environmental and human health consequences; biological control, notably the use of fish and ducks; and a range of cultural and mechanical/physical control measures. None has proven entirely effective, safe, or economically viable and when used in isolation, they often only provide short-term solutions. Control approaches aim to either: i) reduce snail damage to the rice crop by reducing its vulnerability and impairing snail movement; or (ii) focus on reducing snail population density manually, mechanically, chemically or through biocontrol. Once snails are established, however, the best approaches tend to combine several techniques. Raising awareness of the threat among smallholders and implementing a coordinated and rapid response plan should form a crucial part of any management strategy, with community effort at its core.

\section{Invasive apple snail advice and information}

The Kenya Plant Health Inspectorate Service (KEPHIS) has outlined plans to work with stakeholders in the management of $P$. canaliculata. The stakeholders include the Kirinyaga County government, Ministry of Agriculture, National Irrigation Authority, Pest Control Products Board (PCPB), Kenya Agricultural \& Livestock Research Organization (KALRO), Mwea Irrigation Agricultural Development (MIAD), National Government Administration Officers (NGAO), Water Resources Management Authority (WARMA), National Environment Management Authority (NEMA), Department of Public Health, the Presidential Delivery Unit, $\mathrm{CABI}$, the International Centre of Insect Physiology and Ecology (ICIPE) and the University of Nairobi. This forms a multi-institutional technical team (MITT). 


\section{Recommendations}

In light of the confirmed report of an established population of $P$. canaliculata in Kenya, (first record for continental Africa), the following recommendations are proposed for a range of stakeholders. In the absence of effective containment and sustainable management options, spread to other rice-growing regions of Kenya and neighbouring countries is highly likely. For countries which are free of snails, identifying potential introduction pathways, developing risk assessments, implementing a clean certification scheme for traded plants from contaminated areas and elaborating rapid response plans for new incursions will be important to help mitigate impact.

\section{High-level policy makers:}

- Determine the magnitude of the invasive apple snail threat (present and potential) and make policy decisions, backed by available economic estimates and sciencebased evidence.

- Lobby for budgetary allocation to facilitate an immediate, official national response backed by policy and legislation to enable coordinated (potentially mandatory) contingency action to contain and eliminate the invasive apple snail at the earliest opportunity.

- Outline a clear structure and division of responsibility between competent authorities for the development, implementaton and support of eradication/containment measures in Kenya.

- Provide countrywide support for invasive apple snail ecology-based control and farmer/agency education and outreach by establishing a technical working group to spearhead management efforts.

- Make informed, science-based decisions at national level to protect biodiversity, consumers and trade from abuse and misuse of pesticides.

\section{Regulators:}

- Identify pathways for entry and spread of the invasive apple snail to vulnerable areas and contain/quarantine affected areas.

- Ensure awareness is raised to prevent further deliberate and accidental distribution of $P$. canaliculata.

- Organize regular and persistent monitoring schemes for snail egg masses and adults to inform rapid response and containment measures.

- Facilitate, promote and help fast-track registration of lower-risk 'green' products for snail management including biopesticides, botanicals, and the potential use of native natural enemies.

\section{Researchers:}

- Carry out countrywide distribution/delimiting, socio-economic and impact surveys to assess the extent of the problem. 
- Investigate efficacy of native biocontrol agents and test locally available biopesticides and chemo-attractive baits and produce formulations that can maximize the toxic effect on adults and juveniles.

- No rice varieties are resistant to apple snails, but research into modern high-tillering plant types and more tolerant rice seedlings for transplanting can hold better potential to compensate for damage.

\section{Advisory services:}

- Communicate to farmers, using accessible and varied communication approaches, the negative impacts of indiscriminate pesticide use on their health and the environment.

- Consider efficacy, safety, sustainability, practicality, availability and costeffectiveness when recommending control practices.

- Raise awareness (through media and pest alert flyers) and expand extension efforts to facilitate community-based management, coordinating immediate action if the invasive snail is detected.

- Promote good agricultural practice and low-risk, cost-effective options for management such as changes to planting patterns, water management, handpicking, physical barriers and repellent plants.

- Develop an array of cost-effective, clear and harmonized monitoring protocols to be rolled out to smallholders.

\section{Private farms:}

- Follow good agricultural practice advice relating to sustained equipment hygiene, snail removal, alternative cropping systems and planting patterns (avoid ratooning postharvest), including managing water levels and crop establishment age.

- Maintain good records of agronomy, monitoring, interventions, yield, etc., and review regularly to determine the cost-benefit of the control methods used.

- Spraying of registered and crop-approved molluscicide should be based on an action threshold that takes into consideration the expected value of the crop, the expected loss if untreated, and the cost of treatment.

- Farm workers should use the proper personal protective equipment (PPE) when applying pesticides and use the suite of recommended agricultural and cultural practices to manage snail populations.

- Assess the efficacy of other lower-risk products, if available, and adopt for use.

\section{Smallholder farmers:}

- Engage with community extension, regulators, advisory and information services to obtain latest information on government-approved, recommended pesticide use and choose low-risk botanical options if available/affordable (e.g. repellent plants known to have toxic effect on snails across fields and canalettes). 
- Engage with community extension, advisory and information services to obtain latest information on snail identification/life cycle and management.

- Engage in regular surveillance and monitoring for egg masses and adult snails on farms (use bamboo poles/attractants, locally available materials).

- Use a suite of management practices in combination to minimize damage (scouting, hand-picking, trapping, baiting, trenches, physical barriers, etc.), as part of routine, community management action.

- Follow good agricultural practice advice relating to hygiene protocols for equipment/machinery and alternative cropping systems and planting patterns, including managing water levels and crop establishment age (transplanted rice is less vulnerable than direct-seeded rice). 


\section{Acronyms and abbreviations}

CAADP Comprehensive Africa Agriculture Development Programme

$\mathrm{CABI} \quad \mathrm{CAB}$ International (Centre for Agriculture \& Biosciences International)

CARD Coalition for African Rice Development

COVID-19 coronavirus disease 2019

DGIS Directorate-General for International Cooperation

DOA Department of Agriculture

EFSA European Food Safety Authority

ETL economic threshold level

EU European Union

FSN food security and nutrition

GAS golden apple snail

ICIPE International Centre of Insect Physiology and Ecology (icipe)

IPM integrated pest management

IRRI International Rice Research Institute

KALRO Kenya Agricultural \& Livestock Research Organization

KEPHIS Kenya Plant Health Inspectorate Service

MIAD Mwea Irrigation Agricultural Development

MITT multi-institutional technical team

NEMA National Environment Management Authority

NGAO National Government Administration Officers

NIB National Irrigation Board

NRDS National Rice Development Strategy

PCPB Pest Control Products Board

PPE personal protective equipment

RD recommended dose

SDM species distribution model

SNNPR Southern Nations, Nationalities, and Peoples' Region

SRI System of Rice Intensification

SSA Sub-Saharan Africa

WARMA Water Resources Management Authority

WHO World Health Organization

WHOPES WHO Pesticide Evaluation Scheme

WPN wettable powder of niclosamide ethanolamine salt 


\section{Introduction}

The freshwater snail genus Pomacea (family: Ampullariidae) is native to South and Central America, parts of the Caribbean, and Southeastern USA. At least two species, Pomacea canaliculata (Lamarck) and Pomacea maculata Perry, have been spread intra- and intercontinentally and are now widely established in many regions of the world. $P$. canaliculata is native to Argentina and Uruguay, while $P$. maculata is more widely distributed from the La Plata region of Argentina to the Amazon basin of Brazil, including Uruguay and Paraguay, and possibly Bolivia, Ecuador and Peru. These two species have commonly been referred to as 'golden apple snails' (GAS), often without clarifying specifically which species, perhaps both, was involved, or indeed simply assuming it to be $P$. canaliculata (Cowie et al., 2017). They pose serious environmental and economic threats to wetlands and aquatic crops (Pimentel et al., 2000; Cowie, 2002; Nghiem et al., 2013). Pomacea species are also intermediate hosts for nematode parasites that can cause severe health problems in humans (Hollingsworth and Cowie, 2006; Levin et al., 2006; Lv et al., 2011; Vázquez-Silva et al., 2011). P. canaliculata is a voracious generalist feeder, lacks natural enemies in the invaded range, has a high reproductive potential and a broad environmental adaptability (Lach et al., 2000; Cowie, 2002) and is consequently regarded among the world's 100 worst invasive species (GISD, 2021), not least because of its impacts to paddy rice, especially across the Asian introduced range. Extensive documented evidence suggests that its capacity for damage to invaded wetland agricultural systems should not be underestimated, with annual global agricultural economic losses stated as ranging from US\$55 to US\$248 billion/year (R.E. Joshi, 2005). In the Philippines alone, estimates of cumulative economic losses associated with $P$. canaliculata ranged from US $\$ 425$ million to US $\$ 1.18$ billion by the mid-1990s (US $\$ 860$ million to US $\$ 2.39$ billion in 2021 values (US Bureau of Labor Statistics, 2021) since its first introduction in the early 1980s (Naylor, 1996).

Rice is an increasingly important staple food in many countries of Africa and constitutes a major part of the diet in many others. During the past three decades the crop has seen consistent increases in demand, with recognition of its potential to improve the rural lives of farming communities putting it at the forefront of strategic food-security planning policies for many countries.

The recent identification of $P$. canaliculata in Kenya (Buddie et al., 2021) is the first record for mainland Africa and constitutes a clear and present threat to Africa's rice-growing regions. This evidence note therefore synthesizes global information about $P$. canaliculata, including a summary of the research and developments on control measures, estimations of potential losses to East Africa, and a distillation of recommendations for management and containment. This information should be of use for a wide range of stakeholders, including researchers, policy makers, donors and other high-level decision makers, to prioritize investment and interventions in responding to the continuing threat. This evidence note is structured into five sections as follows: 
- Section 1 reviews rice cultivation in Africa, the invasive apple snail impacts across rice-growing regions of the world and its potential establishment across East Africa.

- Section 2 reviews the specific impacts on rice production around the world and projected economic losses for East Africa.

- Section 3 reviews the control methods implemented across the world and provides a summary of pertinent recommendations for East Africa.

- Section 4 summarizes the information, tools and advice sources available to stakeholders.

- Section 5 summarizes recommendations for different stakeholders in Kenya (with relevance to neighbouring African countries).

\section{Rice cultivation and the apple snail problem}

\subsection{History of rice production and trends in Africa}

Rice (Oryza sativa L.) is one of the most important agricultural food crops for more than half of the world's population. It is grown in more than a hundred countries, with a total harvested area of approximately 158 million ha and an annual production of 512 million t in 2019 (milled basis), with year-on-year expansion predicting record highs for utilization in the next few years (FAO, 2020). Rice requires specific growing conditions to be successfully cultivated, it must be grown in several inches of water and once harvested, unprocessed rice is known as paddy rice. Asia represents $90 \%$ of global production and the area under rice represents $29 \%$ of the total output of grain crops worldwide, with Africa accounting for about 10-13\% (Atera et al., 2018).

The African continent has been experiencing a consistent increase in demand for rice. Over the last 30 years, rice has grown in popularity, to take first place on the list of fastest growing staple foods (Mohanty et al., 2013), gradually shifting from consumption only during special events to replace yams, sweet potatoes and cassava in popularity. In certain countries like Tanzania, Nigeria and Niger this transformation is particularly evident and growth has been shown to have a direct link to the growing incomes, rapid urbanization rates, as well as population growth in many of the countries (Balasubramanian et al., 2007; van Oort et al., 2015).

Currently, rice is grown in over $75 \%$ of the 54 African countries and its territories, with a total population of nearly 800 million people depending on rice for their food and livelihoods (Atera et al., 2018). Like Asian countries, almost all rice is grown in sub-Saharan Africa (SSA) is on small farms of $0.5-3$ ha and across five main ecosystems, namely rainfed uplands, rainfed lowlands, inland swamps, irrigated ecosystem and mangrove swamps (Norman and Otoo, 2003). West Africa produced the largest share of rice (paddy) with an estimated 21 million $t$ in 2019, compared to 3.8 million t in East Africa, 0.7 million t in Central Africa and 4.5 million $t$ in southern Africa (excluding South Africa) (FAO, 2020). Becker and Johnson (2001) reported that nearly $90 \%$ of rice in Asia is grown under paddy-field conditions; in contrast, approximately $60 \%$ of rice in SSA is grown in upland ecosystems. 
Over the last decade, the average annual growth rate of rice production on the continent was 10.1\%. This increase was fuelled by an increase in rice areas (7.5\%/year) rather than contributions from yield gains, possibly due to poor quality seed, poor adoption of improved varieties and lack of sound agricultural practices (Arouna et al., 2017). Nigeria is currently the largest rice-producing country in Africa thanks in part to the conscientious efforts of government to place more emphasis on agrarian production rather than rely on oil, which had proved economically risky.

Tanzania is the most important rice-production zone in East Africa where agriculture is a top priority for economic development. Rice-growing areas have increased significantly due to governmental support and this has in turn reduced dependence on imported rice. In the past, farmers mostly focused on local rice varieties that had limited yields. A shift towards modern technology and improved varieties has also seen a marked increase in production levels. Government data shows that the milled rice production increased from 867,000 $t$ in 2008/09 to $2,219,000 \mathrm{t}$ in $2017 / 18$. Although the domestic consumption also increased from $85,000 \mathrm{t}$ to $1,789,517$ t during the same period; the surplus production has put Tanzania as one of the first countries to achieve self-sufficiency in rice production in the region in recent decades. Rice varieties produced in Tanzania such as Supa and SARO-5 (generally referred as Tanzania rice) are extremely popular in markets in eastern and southern Africa (Rice for Africa, 2019). However, the rice yield gap can be high due to a combination of production constraints and suboptimal crop management (Senthilkumar et al., 2018).

Almost $40 \%$ of the rice consumed in Africa is imported (Yamane, 2019), as the increase in production is not able to keep pace with the sharp increase in rice consumption (Soullier et al., 2020). Despite many government drives towards self-sufficiency, the economic burden of imports remains high and many countries of the region, on average, allocate less than $5 \%$ of their budget to agriculture (Fontan Sers and Mughal, 2020). This is in spite of evidence of significant beneficial effects of public agricultural spending on food security for the countries which allocate greater proportions of their budgets to agriculture (Fontan Sers and Mughal, 2020).

Against this backdrop, the Coalition for African Rice Development (CARD) was established in 2008, led by a consultative group of international and African organizations and institutions which are prominent in rice development in Africa (Satoyama et al., 2014). CARD aimed to double rice production in SSA, by providing countries with various supports for rice sector development. By building on existing structures, policies and programmes, such as the national agricultural research organization of Africa, the Africa Rice Center (AfricaRice), the Comprehensive Africa Agriculture Development Programme (CAADP) and the Africa Rice Initiative (ARI), CARD aimed to respond to the increasing importance of rice production in Africa. CARD Phase 2 started in 2019, with a renewed target of further doubling of rice production in SSA, from 28 million t to 56 million t for the next 12 years (by 2030). CARD supports its African member countries, including Kenya, by preparing their National Rice Development Strategy (NRDS) (Rice for Africa, 2021), through triannual workshops.

Rice production in Kenya dates back to 1907 when it was introduced from Asia by Europeans (Onyango, 2014). Rice is produced both under irrigation (involves continuous flooding) and upland conditions (Atera et al., 2018). In Kenya, rice is mainly produced under irrigation by small-scale farmers in counties that include: Kirinyaga (Mwea), Busia (Bunyala), Tana River (Tana Delta, Bura), Kwale (Vanga cluster), Kisumu (Ahero, West Kano, South West Kano, smallholder irrigation schemes within Kano Plains), Migori (Lower Kuja), Homa Bay (Maugo, 
Oluch Kimira), Siaya (Anyiko) and Taita Taveta (Kimorigho, Buluma). Rice is also grown under rainfed conditions in Busia, Bungoma, Kakamega, Kwale, Kilifi, Meru, Isiolo, Migori, Baringo and Murang'a and about 300,000 rice farmers provide labour and also earn their livelihood out of the crop's production (NRDS 1). The Mwea Rice Growers Multipurpose Cooperative Society (MRGM) is the largest farmer-run cooperative within the Mwea Irrigation Scheme in Kirinyaga County, producing 80-88\% of rice in the country (Mati et al., 2011; Ndiiri et al., 2013; Onyango, 2014). Most farmers in Mwea grow rice once a year, sowing between July and August and harvesting between December and January (Abdullahi et al., 2003; Ngige, 2004). The other large mills include government-owned Mwea Rice Mills and National Cereals Produce Board in Kirinyaga County, TARDA in Tana River as well as Western Rice Mills and Lake Basin Development Company in Kisumu. There are eight large private mills in Kirinyaga and one in Kiambu (Capwell Industries). In addition, there are several small privately owned mills spread across the major rice-growing counties.

Historically perceived as a cash crop, rice has rapidly grown in importance in Kenya as a food crop and annual rate of increase in consumption is $12 \%$, compared to $4 \%$ for wheat and $1 \%$ for maize (Atera et al., 2018). Since 2008, the area under rice cultivation has broadened by $55 \%$ from 16,734 ha to 25,966 ha in 2018 , paddy production has increased four-fold from $21,881 \mathrm{t}$ to $110,325 \mathrm{t}$ in 2018 , and on-farm productivity has more than doubled from $1.3 \mathrm{t} / \mathrm{ha}$ to $4.25 \mathrm{t} /$ ha thanks to the Government of Kenya's efforts at enhancing production, processing and marketing of rice through the NRDS. There are two main cultivated species of rice, $O$. sativa, the most common and Oryza glaberrima L. Kenyan consumers prefer aromatic rice varieties (such as the pishori rice grown in Mwea) which have a niche market especially among households with improved incomes (Kioko et al., 2015). However, according to the NRDS 2 (2019-2030), the retail price of these varieties is prohibitive. Though imported rice is of superior quality in terms of purity and percentage of broken grains compared to the local nonaromatic rice, it is usually cheaper. None the less, preference for the locally produced nonaromatic rice is higher, especially in Kirinyaga County. Despite the progress made, the national markets continue to be dependent on supply of rice from Asia and the region to meet consumer requirements (Rice for Africa, 2020). Rice is one of the priority crops in the Big4 Agenda in Kenya and a priority value chain in the Agriculture Sector Transformation and Growth Strategy (2019-2029). Rice consumption has been growing much more rapidly in the country than production and is expected to reach $1,292,000$ t by 2030 . In order for Kenya to attain self-sufficiency in rice production by 2030 , the total domestic rice production must increase at the rate of $9.3 \%$ per annum (Atera et al., 2018).

To meet the growing demand for rice, Kenya has embarked on an aggressive campaign, guided by its NRDS 2, which runs from 2019 to 2030. This aims to catalyse over a sevenfold increase in domestic milled rice production, from 112,000 t in 2018 to 846,000 t in 2030.

The recent coronavirus disease 2019 (COVID-19) crisis has negatively affected rice exports across Africa, largely due to delays from border closures or movement restrictions. Exporters to Kenya, Rwanda, Uganda and South Sudan (through Uganda) have indicated a slowdown with losses in export revenue of between $40 \%$ and $60 \%$ per month as a result of COVID-19 (Future Agricultures, 2020). To enhance rice production and hence boost food security, Kenya's policy makers must acknowledge and address the impediments that exist across the rice value chain and this includes biotic constraints such as non-native pests, of which apple snails are among the world's most damaging for this crop. This is particularly relevant as the 
COVID-19 pandemic is a multiplier of vulnerability, compounding threats to food security and nutrition (FSN), while exposing weaknesses in food systems (GAIN, 2020).

\subsection{Biology and identification of invasive Pomacea species}

Pomacea canaliculata and Pomacea maculata have commonly been referred to as 'golden apple snails' or 'GAS', a term primarily applied in South-east Asia to South American species because their shells are often apple-like, large, round and sometimes greenish in colour (Lai et al., 2005; Joshi and Sebastian, 2006). However, widespread confusion surrounding their taxonomy has meant that much of the extensive body of published (and unpublished) literature is difficult to interpret, with reports failing to clarify specifically which species, or if both, were involved, or indeed simply assuming it to be $P$. canaliculata (Cowie et al., 2017). As is frequently the case in species with phenotypically variable shells, species boundaries have been differently interpreted (Cazzaniga, 2002), names have been synonymized and applied inconsistently (Hylton Scott, 1958; Thiengo, 1987; Thiengo et al., 1993), or species have simply been identified incorrectly (Cowie et al., 2006). The use of various common names for $P$. canaliculata, in both English and other languages has also added to the confusion (Cowie et al., 2006).

There is no consensus on how many species are in the genus Pomacea (family: Ampullariidae), but it is thought to include around 50 species (Hayes et al., 2015) and is a clearly distinguishable taxonomic entity, although the systematics of the genus remain dynamic. The two most documented species, $P$. canaliculata and $P$. maculata, together with Pomacea lineata (for which little information is available) form the 'canaliculata complex' and the three are almost indistinguishable from each other in the field (EPPO, 2014). Differentiation of Pomacea species on a morphological basis is difficult, even for experts, as intraspecies variation is high across the distribution range and morphological similarities are shared between many different species. The traditional concept of a species does not fit well with the differences in morphology, life history, and other variation exhibited by these snails (Ramírez et al., 2003; Cowie et al., 2006; EFSA Panel on Plant Health, 2012) but none the less, ampullariid taxonomy has until recently relied almost exclusively on shell morphology (Keawjam and Upatham, 1990). P. maculata can be distinguished from P. canaliculata somewhat reliably as adults, based on features of the shell: that of $P$. maculata usually having a yellowish to reddish-orange wash round the edge of the shell aperture, while $P$. canaliculata is unpigmented; and more subtly in the greater angulation of the whorl shoulder in P. maculata (Hayes et al., 2012). Definitive identification, however, must rely on molecular characters (Cowie and Hayes, 2005), internal anatomy or reproductive characteristics for a clear distinction (Hayes et al., 2012, 2015). Hatchlings of the two species are readily distinguished as the number of eggs is greatest in $P$. maculata but the eggs are smaller; hence hatchlings of $P$. canaliculata are roughly twice as big as those of $P$. maculata (Hayes et al., 2012). However, the two species differ most clearly genetically (Hayes et al., 2012). Improving morphological and molecular sequencing has allowed the taxonomy of Ampullariidae and the genus Pomacea to be clarified further (Matsukura and Wada, 2017) and this has been particularly useful for distinguishing $P$. maculata (formerly often referred to as its junior synonym Pomacea insularum) from P. canaliculata (Rawlings et al., 2007; Hayes et al., 2008, 2009, 2012; Matsukura et al., 2008; EFSA Panel on Plant Health, 2012). Results from molecular analysis have also highlighted possible hybridization events (Hayes et al., 2012; Matsukura et al., 2013). 
Ampullariids are primarily freshwater snails, although some may be able to tolerate low levels of salinity (Prashad, 1925; Santos et al., 1987; Fujio et al., 1991), but they generally do not live in brackish waters. Many species, including Pomacea, inhabit slow-moving or stagnant water in lowland swamps, marshes, ditches, lakes and rivers (Keawjam, 1986) and some species can almost be considered pre-adapted for life in rice paddies, taro patches, and other similar artificial habitats in which aquatic crops are grown. The natural range of $P$. canaliculata was found to be restricted to the Lower Paraná, Uruguay and La Plata basins of Argentina, although it is possible that it may also occur in the lower reaches of the Upper Paraná and parts of southern Brazil which form a phytogeographic unit and have similar habitats and watershed connections. Hylton-Scott (1958) reported that $P$. canaliculata inhabited relatively still water and it is not present in the Amazon basin (CABI, 2020). Thus $P$. canaliculata appears restricted to a narrower southern range, whereas $P$. maculata ranges extensively throughout much of South America.

Unlike most other snails, $P$. canaliculata is not hermaphroditic and male and female snails reproduce if water conditions and food supply are adequate. Sexual maturity is reached when the snail reaches $2.5 \mathrm{~cm}$ in diameter. Copulation and spawning tend to be time-consuming activities. Intercourse can last 10-20 h (and males fast during this time) while the egg-laying process can take up to $5 \mathrm{~h}$. In addition, males tend to choose larger females in order to produce more and healthier offspring (Estebenet and Martin, 2002). A single female of $P$. canaliculata can lay up to 500 eggs at a time. Hayes et al. (2012) provide the most comprehensive description of $P$. canaliculata and $P$. maculata and a brief summary of morphological characteristics and life cycle is provided below.

Pomacea eggs form an opaque and brightly coloured, conspicuous mass (Figure 1). Individual eggs are spherical (<2.00 $\mathrm{mm}$ to $>3.00 \mathrm{~mm}$ in diameter), calcareous and deep pink-red to lighter orange-pink colour, becoming paler as the calcium hardens and eventually turning whitish pink before hatching. They are laid in a mass just above the water on emergent surfaces such as vegetation and other firm substrates (e.g. concrete bridges, walls, logs, rocks) as snails are unable to swim. The height above water varies from a few centimetres to $\sim 2 \mathrm{~m}$. The number of eggs per clutch averages from $\sim 260$ to $\sim 1500$, ranging from as few as 12 to as many as $\sim 1000$ (Tamburi and Martín, 2011; Hayes et al., 2012). Females usually lay one egg batch about every fortnight if conditions are favourable and eggs need a good supply of air; hatching may be delayed if eggs are temporarily submersed (Pizani et al., 2005) or at a lower temperature or fail altogether if they become submerged. Newly hatched snails are tiny, with shells that can be less than $2 \mathrm{~mm}$ in diameter, but grow rapidly and drop from where the eggs were laid into the water below. Hatchlings develop into juveniles 15-25 days after hatching, and the snails become mature adults 45-60 days later. $P$. canaliculata are first able to lay eggs when they reach a shell diameter of about $2.5 \mathrm{~cm}$ and oviposition takes place predominantly at night, or in the early morning or evening (Halwart, 1994; Albrecht et al., 1996) with the interval between successive egg laying variably reported as 5-14 days (Chang, 1985; Albrecht et al., 1996).

Ampullariids are dioecious (separate sexes), internally fertilizing and oviparous (producing eggs that hatch outside the body). Shells are smooth, thin, coiling dextrally (i.e. when viewed with the apex uppermost the aperture is on the right side of the shell). Colour may be dull brown to greenish-brown (Figure 2) or dark chestnut, sometimes with dark-brown spiral bands of variable number and thickness. The whorls are rounded and the suture between the whorls is deeply channelled. The aperture is usually ovoid to kidney shaped, and the inside lip of the 
shell is unpigmented. Pomacea species have an operculum - a discrete trap-door-like structure attached to the upper part of the animal's foot that can seal the shell closed as it withdraws within and prevents desiccation. The foot is oval with a squarish anterior edge and they have four, long, tapering tentacles which are highly extensible with large but short eye stalks at their outer bases. A very long collapsible siphon allows them to breathe at the surface when extended, distinguishing them from other freshwater snails which often lack a siphon and possess only two triangular tentacles and no operculum. A structure within the mouth of $P$. canaliculata makes rasp-like cuts on its host plants; damage is rapid.

Pomacea spp. have an estimated lifespan of 1-4 years (Hayes et al., 2015). In subtropical and warmer temperate zones, snails can aestivate in mud for many months (Hayes et al., 2015) and their lifespan may be up to 3-4 years, with a lower number of generations per year and potential for high winter mortality. With elevated temperatures found in more tropical and subtropical zones, lifespan is shorter, lasting 1-2 years, as hibernation is not necessary (Hayes et al., 2015), but the snails have a continuous reproductive period until death (Estebenet and Martín, 2002). R.E. Joshi (2005) observed that during the off-season (after rice harvesting but before rice planting) in the Philippines, the small-sized invasive apple snails (10-15 mm) have low mortality rates, but the mortality increased with their size. This has important implications on snail management. Reproductive activity was found to start after hibernation at a water temperature of $18^{\circ} \mathrm{C}$ (Wu et al., 1995; Albrecht et al., 1999; Estebenet and Martín, 2002; Yoshida et al., 2009; Seuffert et al., 2010).
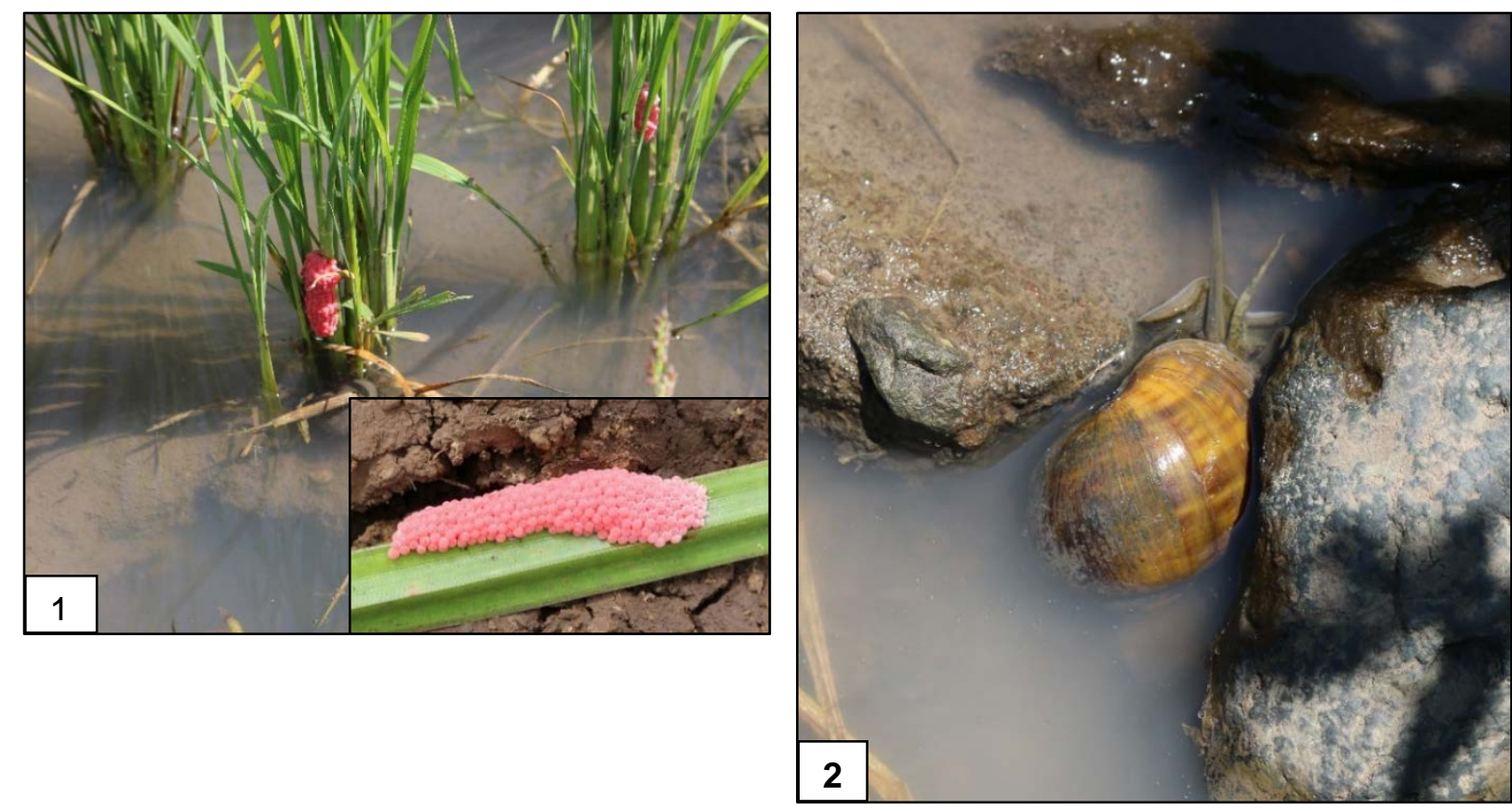

Fig. 1. Conspicuous pink egg clutches of Pomacea canaliculata on rice plants (from Mwea Irrigation Scheme Kirinyaga, Kenya, 2020). Credit: Fernadis Makale. Fig. 2. Adult $P$. canaliculata snail (from Mwea Irrigation Scheme, Kirinyaga, Kenya, 2020). Credit: Fernadis Makale.

\subsection{Invasive apple snail spread around the world}

The deliberate and repeated introduction of $P$. canaliculata and $P$. maculata from Argentina, into East and South-east Asian rice-growing regions in the 1980 s has proved disastrous, with 
long-lasting impacts on agricultural yields, farm income, human health and natural ecosystems (Naylor, 1996; R.C. Joshi, 2005a, b; Hayes et al., 2008).

Introduced for cultivation as a high-protein source for domestic consumption and gastronomic export, its characteristic traits of polyphagous feeding (Wong et al., 2010; Burks et al., 2011; Morrison and Hay, 2011; Saveanu and Martín, 2013) and rapid, prolific breeding potential (Keller et al., 2007; Kyle et al., 2013), are the very traits which made this so-called 'golden miracle snail' such a successful invader (Naylor, 1996). Already a well-known pest of coastal rice-growing areas of Suriname in the 1950s (Acosta and Pullin, 1991), the promise of economic returns from snail cultivation none the less saw their introduction into Taiwan, Japan and the Philippines in the early 1980s, with subsequent introductions to China, South Korea, Malaysia, Thailand, Indonesia, Vietnam, Cambodia (Cowie, 1995a; Chanthy, 2002; Cuong, 2002, 2006; Huan and Joshi, 2002; Suharto, 2002; Lee and Oh, 2006; Preap et al., 2006; Yahaya et al., 2006; Marwoto et al., 2018), and later in the 1990s into Laos (Anderson, 1993; R.C. Joshi, 2005a, b; EFSA et al., 2020). However, a combination of unpalatability, prohibitive health import restrictions from foreign markets and the associated drop in market value resulted in negligence by would-be producers, and snails were released/escaped into irrigation systems and public waterways (Naylor, 1996). Spread thereafter was rapid and widespread; within 5 years, the proportion of wet-rice area infested by the GAS rose from less than 3\% to between 15\% and 25\% in Taiwan and the Philippines (Mochida, 1991; Ketelaar, 1993) and to around three-quarters of rice-growing districts in Japan and Vietnam (Naylor, 1996; Yusa and Wada, 2002). Winter temperatures may limit the northern spread of $P$. canaliculata in Japan (Ito, 2002), although behavioural adaptations and acclimation to these cooler temperatures have allowed overwintering further north than would otherwise be possible (Wada and Matsukura, 2007; Matsukura et al., 2008). The sheer abundance of snails in Asian agricultural systems led to unintentional introductions to Malaysia from Thailand on contaminated imports of water spinach (Naylor, 1996). In 2009, invasive populations of Pomacea species were discovered in Brunei Darussalam (Hanifah et al., 2018) and a first record was reported in Southern Iraq (Al-Abbad et al., 2015).

The Asian subcontinent is also threatened by apple snails' rapid spread in Pakistan, probably from the aquarium trade (Baloch et al., 2012; Baloch, 2017), Sri Lanka (Nugaliyadde et al., 2001; Epa, 2006) and Myanmar (Myint and Ye, 2017). The agricultural and environmental consequences of further spread to India and Bangladesh in particular, a country of rivers and canals and frequent flooding, would be serious.

P. canaliculata was introduced to the Pacific Islands, notably Hawaii through the domestic aquarium trade around 1989, although there are unconfirmed anecdotal accounts that it was present some years earlier (Cowie, 1995b; Levin et al., 2006; Cowie et al., 2007). Accidental spread has been reported in Hawaii from small juveniles, inadvertently transported on taro parts used for propagation (Levin et al., 2006), and eggs have also been transported on boats (EFSA Panel on Plant Health, 2012). It was also recorded in Guam in 1989 (Smith, 1992) and in other areas of Oceania such as Papua New Guinea and New Zealand (Orapa, 2006; Hayes et al., 2008; Collier et al., 2011; Cowie et al., 2017). In North America, P. canaliculata is now present in California, Arizona, Florida, Georgia, Texas (Howells and Smith, 2002; Howells et al., 2006), Alabama (Martin et al., 2012) and South Carolina (Benson, 2018). Invasive apple snails have also been reported in Europe, the first report from the Ebro Delta in Spain (López et al., 2010; R.C. Joshi, unpublished trip report, 10-19 July 2015) with data suggesting that both $P$. maculata and P. canaliculata could be present (Andree and López, 2013). While they 
were eradicated from this area, they subsequently spread to a new region in northern Spain (Joshi, 2016; Joshi and Parera, 2017) but were eradicated there too in 2020 (EFSA et al., 2020). Small populations of Pomacea spp. were also successfully eradicated from municipalities in Switzerland and France (EFSA et al., 2020). Unconfirmed reports of $P$. lineata (possibly misidentified and actually $P$. canaliculata) occur from South Africa (Berthold, 1991) and Shivambu et al. (2020) reported $P$. canaliculata from the South African pet trade. Pomacea canaliculata has also been detected in La Réunion and Mauritius (EFSA et al., 2020; EPCO, 2020). Pomacea spp. invasions have also occurred in Dominican Republic (Rosario and Moquete, 2006), and in Haiti (R.C. Joshi, unpublished USAID consultancy report, 9-24 December 2018). The global distribution of the apple snail is shown in Fig.3.

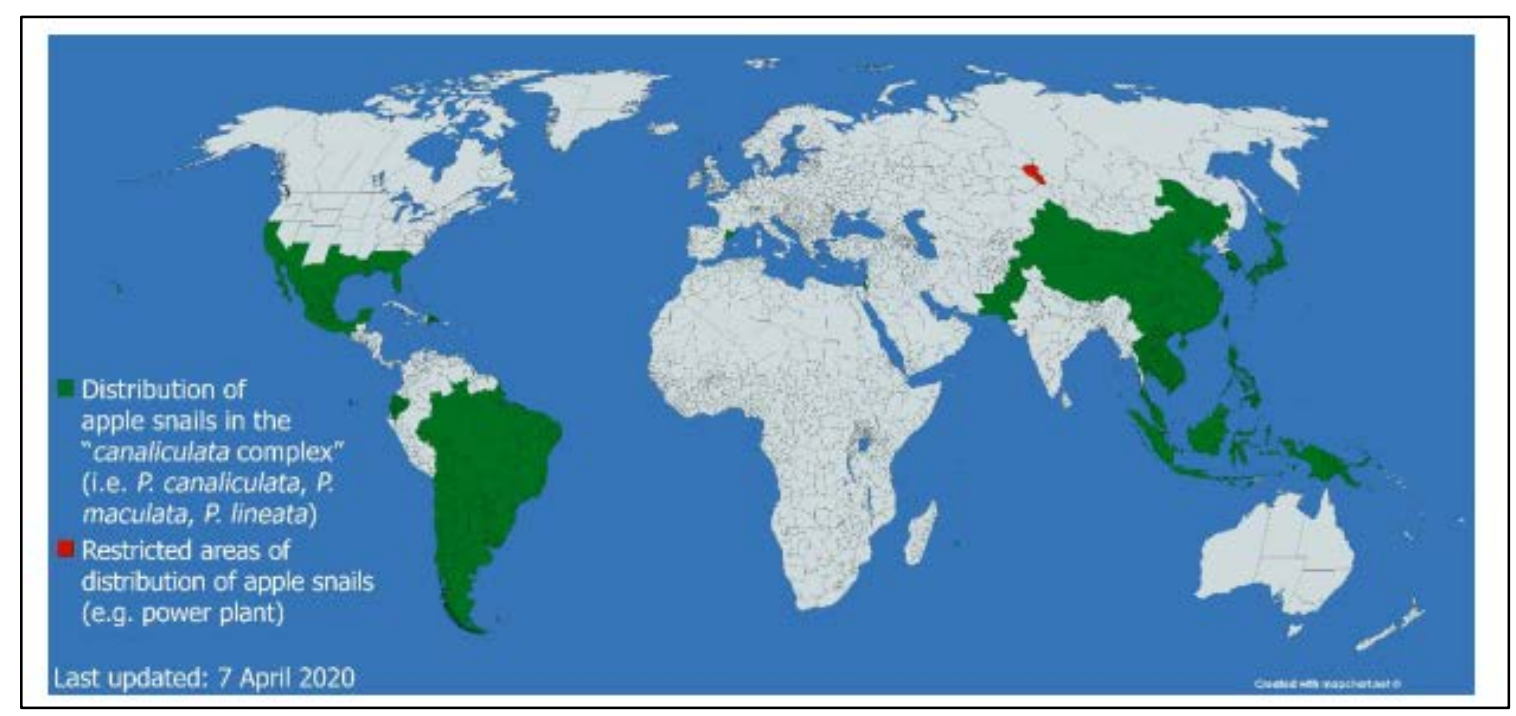

Fig. 3. Global distribution of apple snails in the 'canaliculata complex'. Reproduced from EFSA et al. (2020).

Natural dispersal rates are relatively low, as the snails are restricted to damp habitats and are not capable of rapid movement. Flooding from heavy rains contribute to their dispersal over low-lying areas and birds have been found to transfer egg clutches through nest-building activities (Levin et al., 2006). Pomacea adults are not wholly restricted to water, and can move overland for short distances between sources of water. They are capable of dispersing downstream at a faster rate than upstream, as they can be carried along with floating vegetation and in water currents. The conspicuous egg masses are the most detectable life stage in the wild and adult snails are more cryptic, but if found, the sheer size of mature specimens is a strong indicator of identity (Hayes et al., 2012). It is predicted that the climatically suitable habitats for $P$. canaliculata will further increase with projected scenarios of global warming (Lei et al., 2017).

\subsection{Invasive apple snail host range and general impacts}

According to the classification of functional feeding groups of aquatic invertebrates by Cummins and Klug (1979), apple snails feed by shredding (obtaining pieces of submersed materials, mainly with the jaws), scraping (obtaining material adhering to submersed surfaces, mainly with the radula) and collecting (obtaining material from the water surface with the foot). All three mechanisms can be used by the same individual in rapid succession to obtain 
vegetal, animal or microbial materials (Demian and Lutfy, 1966; Cazzaniga and Estebenet, 1984; Aditya and Raut, 2001; Cowie, 2002; Morrison and Hay, 2011).

The most widely recognized impacts of invasive Pomacea are therefore linked to this uncommon ability to successfully feed at rapid rates on a broad diet. Because of powerful enzymes and ingestion of lithic particles to amplify mechanical digestion, they can also effectively process their food (Martín et al., 2019).

Apple snails such as $P$. canaliculata mostly inhabit lentic or slow-running water courses in tropical to warm temperate regions and their diverse feeding modes and trophic flexibility are a relevant trait in their broad and continued invasion success. They feed primarily on aquatic macrophytes, including a diverse number of crops such as rice (Oryza sativa), taro (Colocasia esculenta), morning glory (Ipomoea aquatica), lotus (Nelumbo nucifera), mat rush (Juncus decipiens), Chinese mat grass (Cyperus monophyllus), watercress (Rorippa spp.), Japanese parsley (Oenanthe stolonifera), water chestnuts (Trapa bicornis), wild rice (Zizania latifolia), azolla (Azolla spp.) and water lilies (Nymphaea spp.) (Mochida, 1991; Dancel and Joshi, 2000; Joshi et al., 2001; Yusa et al., 2006; Horgan, 2018). Although many of these plants are quite unpalatable, in monocultures they are almost the only trophic option. $P$. canaliculata can also consume other trophic resources (e.g. carrion) and that is likely to play an important role in its persistence and contribute to its impacts in invaded wetlands (Manara et al., 2016).

Their ability to survive even after the most palatable aquatic macrophytes have been exhausted was highlighted by Saveanu and Martin (2015), who reported pedal surface collecting (capture of surface material) in $P$. canaliculata as an adaptation to cope with fluctuating trophic resources. Qiu et al. (2011) also found $P$. canaliculata was capable of utilizing both fresh and decaying leaves of adequate levels of nutrients allowing for greater colonization potential throughout the year. Apple snails can deplete the palatable aquatic vegetation, favour the dominance of unpalatable species or induce the expression of chemical defences (Saveanu and Martin, 2013) and their feeding provokes marked changes in wetlands as well as causing major economic losses in aquatic agricultural systems (Cowie, 2002; Carlsson et al., 2004b; Joshi and Sebastian, 2006). Pomacea are also known to bioaccumulate toxins (Berry and Lind, 2010), pesticides (Coat et al., 2011) and heavy metals (Deng et al., 2008; Kruatrachue et al., 2011; Dummee et al., 2012; Vega et al., 2012; Peña, 2017).

By virtue of its large size, high trophic flexibility, high feeding rates and high fecundity (Burlakova et al., 2009; Burks et al., 2011; Morrison and Hay, 2011; Hayes et al., 2015; Saveanu et al., 2017; Tiecher et al., 2017), other species of snails are easily outcompeted and $P$. canaliculata is also able to prey on adults, young snails and egg masses of other snails (Cazzaniga, 1990, 2006; Kwong et al., 2009). This, intraguild predation on egg masses has been shown to be an important interspecific interaction among freshwater pulmonate snails of similar sizes (Turner et al., 2007) and is expected to be even more important in the case of $P$. canaliculata, due to its powerful radula and jaws and its larger size. The effects of $P$. canaliculata on other snails are expected to be strong in the areas invaded, where it can reach high densities, monopolize secondary production, and provoke ecosystem changes (Carlsson et al., 2004b; Kwong et al., 2010; Horgan et al., 2014; Tricarico et al., 2016).

In Thailand, introduced Pomacea species have also been found to predate bryozoans (Wood et al., 2006), and may have a higher tolerance of variable environmental conditions, in addition to possibly being competitively superior to native snail species, including species which are 
already threatened by habitat loss and modification (Köhler et al., 2012; Marwoto et al., 2018; $\mathrm{Ng}$ et al., 2019).

The herbivory of invasive Pomacea and release of nutrients into the water and subsequent phytoplankton has also been linked to eutrophication (Martín et al., 2019) while eradication of submersed macrophytes may also facilitate sediment resuspension and raise water turbidity, altering both biodiversity and the integrity and functioning of the ecosystem (Carlsson et al., 2004b). Thus, the impacts of Pomacea are not only on closely related or congeneric species but also on other evolutionarily distant species and on the natural balance of the invaded area in general and they are thought to have pushed some particularly fragile ecosystems in ASEAN countries into irreversible decline.

Impact of opportunist predators has also been reported where ingestion of the poisonous eggs of $P$. canaliculata adversely affect the digestive system of amphibians (Brola et al., 2021). Pomacea management has also had collateral impacts on ecosystems and in the Philippines for example, populations of native ampullariid snail species have experienced sharp declines perhaps as a result of extensive and indiscriminate application of pesticides to combat the introduced P. canaliculata (Anderson, 1993; Chaichana and Sumpan, 2014; Schneiker et al., 2016; Cowie et al., 2017).

\subsection{Invasive apple snail impact on human health}

Apple snails are species of concern not only because of their adverse agricultural and ecological impacts but also because of the potential risk that they pose to human health when used as a food resource. $P$. canaliculata and other species can serve as intermediate hosts of zoonotic nematode parasites, such as Angiostrongylus cantonensis, Echinostoma ilocanum, Echinostoma revolutum and Gnathostoma spinigerum (Brandt, 1974; Keawjam, 1986; Komalamisra et al., 2009; Yang et al., 2013). The rat lungworm nematode parasite ( $A$. cantonensis) can cause potentially fatal eosinophilic meningitis in humans and animals if the infective larval stage is ingested either by eating infected snails or in mucus trails left by infected snails on edible plants (Wang et al., 2008; Dorta-Contreras et al., 2011), G. spinigerum reportedly parasitizes cats, dogs and humans in Thailand and Japan (Komalamisra et al., 2009) and Angiostrongylus costaricensis causes abdominal angiostrongyliasis in humans (Miller et al., 2006). They can also act as vectors for Schistosome cercariae, cause of cercarial dermatitis or swimmer's itch, and for a fluke that causes intestinal problems (Hollingsworth and Cowie, 2006).

Schistosome dermatitis occurs when a person becomes the accidental host of cercariae (the free-swimming larval stage) of non-human schistosome trematodes. The cercariae penetrate the skin where they soon die, causing a hypersensitive reaction of the skin (Hoeffler, 1974). Leedom and Short (1981) reported dermatitis caused by cercariae from Pomacea species in the USA. In Kenya, farmers expressed worries that the newly found Pomacea snails may cause waterborne diseases like schistosomiasis (bilharzia) as many cannot afford gumboots to protect themselves from such diseases.

The spread of $P$. canaliculata may therefore facilitate the spread of these zoonotic species by completing the life cycle required to infect mammalian hosts, with global warming providing further opportunities for the snail, a stenothermal organism, to enlarge its potential habitat and colonize new habitats (Lv et al., 2006). 
In addition, the empty shells of dead snails, perhaps following pesticide application, have been reported as a health hazard as they can cut the feet of people planting, harvesting or otherwise managing the crop (Cowie, 2002; Douangboupha and Khamphoukeo, 2006; HendarsihSuharto et al., 2006). The overuse of pesticides to control the snails and the often poorly regulated application of dangerous formulations can also cause human health and environmental safety problems (Cowie, 2002). Pomacea species are also capable of toxin bioaccumulation (Berry and Lind, 2010) and this capacity also poses a potential threat to human and ecosystem health.

Apple snails have also been reported to accumulate high concentrations of metal pollutants in their tissues and thus can affect animals at higher trophic levels, including humans.

Burkett-Cadena and Unnasch (2013) found the Asian tiger mosquito (Aedes albopictus) was capable of exploiting discarded apple snail shells as larval development sites in Florida and could potentially contribute to mosquito proliferation.

\subsection{Current spread and distribution of invasive apple snail in Africa}

Ampullariids (apple snails) are thought to have originated from Gondwanan lineages that inhabited what is now Africa (Hayes et al., 2009). Fossil records are scarce (e.g. Prashad, 1925; Pilsbry and Bequaert, 1927; Fischer, 1963; Boss and Parodiz, 1977; Martín and De Francesco, 2006) but the Gondwanan origin is supported in part by the distribution of the two most basal genera in the family, Saulea and Afropomus, in current-day Sierra Leone and Liberia on the African west coast, and the presence in Africa of two remaining Old World genera Lanistes and Pila (Hayes et al., 2015). Pila occurs in Africa and Asia, Lanistes, Afropomus and Saulea only in Africa.

Due to the challenges of differentiating between the species, there have been uncertainties over the identity of apple snails found in different countries worldwide. However, up until recently, Pomacea snails in the 'canaliculata complex' were not recorded from the African mainland and were only detected in Réunion and Mauritius (EFSA et al., 2020; EPCO, 2020). $P$. canaliculata was detected in areas utilized for taro cultivation in La Porte Providence, Flacq (east part of Mauritius) and first detected in La Réunion in 2006.

Following reports that an unknown snail species had invaded the Mwea Irrigation Scheme in Kirinyaga County, where over $70 \%$ of the country's rice is grown (Atera et al., 2018), surveys were undertaken by CABI in September 2020. Farmers had reported snails from close to 222 ha of Tebere and Ndekia section of the 10,117 ha grown, with associated damage to $92 \%$ of newly transplanted rice seedlings (Ivan Rwomushana, CABI Kenya, 2020, personal communication). DNA barcoding analyses confirmed the identity of the snails as $P$. canaliculata, which constitutes a first record for Kenya and mainland Africa (Buddie et al., 2021).

Intense flood events are becoming more commonplace in Kenya due to extreme weather worsened by global warming. Many recent floods have ruined harvests in several riceproduction hubs and could be a further pathway for snail spread into other regions.

According to the European Food Safety Authority (EFSA Plant Health Newsletter 2020), Pomacea eggs were first observed in Kenya but not recognized as a threat in 2019, though official reports suggest February 2020 was the first sighting. A great deal of media coverage subsequently ensued with the Kenya Plant Health Inspectorate Service (KEPHIS) and stakeholders, including the Kirinyaga County government, began an initiative to control the 
snails. It had also been noted as a threat to the 1500 acres (607 hectares) of the bordering lower areas that receive water from upper units. The pathway for introduction to Kenya remains unknown and no permits for import have come to light although speculation of intentional introduction as a biological control agent for weeds has been raised in the press.

In Japan, introduction of $P$. canaliculata was reported as a biocontrol agent for weeds in rice systems (Okuma et al., 1994; Wada, 2004). Great caution has always been urged when considering $P$. canaliculata as a biological control agent for aquatic weeds (Cazzaniga and Estebenet, 1985; Cazzaniga, 2006) as the risks very much outweigh the potential benefits and it is only appropriate in areas in which it is already established (Wada, 1997; Wada et al., 2002; Lee et al., 2019). Several species, notably the apple snails, Pomacea spp. and Marisa cornuarietis, and the thiarid Tarebia granifera, are known to have also been used as potential biocontrol agents of schistosomiasis host snails because they prey on or compete with pulmonates such as Biomphalaria spp. and Bulinus spp. Whether this competition is for resources, such as food, or due to interference (e.g. physical contact) facilitated by the invasives' greater population densities, is not clear.

In their natural habitat, apple snails can remain active throughout the year given the right environmental conditions (i.e. warm and relatively humid), but they usually aestivate during parts of the year to prevent drying out. Temperatures and rainfall are the two main factors that determine their activity levels (Coelho et al., 2012). High humidity allows the snails to remain out of water for some time without desiccation and they can reportedly disperse across land during these high humidity periods (Kappes and Haase, 2012). Such land dispersal activities account for localized spread, and do not make up the majority of apple snail dispersal; $P$. canaliculata has the ability to float and can move long distances within a water system; in canals it was found to move more than $100 \mathrm{~m}$ upstream or more than $500 \mathrm{~m}$ downstream in 1 week (Ozawa and Makino, 1989). Snails need access to flowing water or flooding events to move naturally (e.g. caused by heavy rain). Connected rice fields, rivers, natural and artificial canals provide an effective structure for the snails to spread (Yusa et al., 2006; EFSA Panel on Plant Health, 2012). Downstream movement (by drifting) in rivers is at least ten times further than upstream movement (by crawling) (Kappes and Haase, 2012; EFSA Panel on Plant Health, 2013). This is mostly effective at local and regional levels and passive natural spread over several kilometres during 1 year is possible.

In addition, studies on snails other than Pomacea spp. showed that waterbirds may contribute to the spread of those aquatic invertebrates, which can remain attached to the body of flying birds or on being ingested survive the passage through the digestive system (van Leuwen and van der Velde, 2012; van Leuwen et al., 2012). Ichinose and Yoshida (2001) reported that fast water flow may impede movement and prevent snails from expanding their range upstream and Ito (2002) found established populations remained restricted to small areas if the flow was very still.

However, factors restricting the dissemination of snails within a water system are not fully understood and the broad ecological and thermal tolerance of $P$. canaliculata is well documented (Eversole, 1992; Schnorbach, 1995). In the native range, studies indicate that $P$. canaliculata distributions are determined by a combination of physicochemical (salinity, alkalinity) and geographic (mountains) barriers in conjunction with stochastic patterns of extinction-colonization events related to local variability of climatic and hydrological conditions (Martín et al., 2001; Martín and De Francesco, 2006; Seuffert and Martín, 2013). However, in 
the non-native range this species can be found in suboptimal habitats, indicating that it can at least survive in these habitats for a period of time (Kwong et al., 2008).

Unintentional movement by humans from areas where the snail is already present into currently pest-free areas may be possible, for instance on cultivation tools where egg masses had been deposited and when transplanting rice plants from infested rice paddies (Cowie, 2002; Smith, 2006; EFSA Panel on Plant Health, 2012). The expected rate of human-assisted spread can be effective over large distances, but these are difficult to estimate. In tropical regions, however, released from the seasonality of its natural range, with rapid growth and breeding, and hence rapid succession of generations all year round (Naylor, 1996), $P$. canaliculata population expansion is a distinct possibility.

Preliminary status surveys undertaken in late 2020 in the three major rice-growing schemes of Kenya (Mwea, Ahero and West Kano) suggest that $P$. canaliculata was restricted to the Mwea Irrigation Scheme (Fernadis Makale, 2020, unpublished work). A restricted distribution could offer a strong opportunity to contain or even eradicate the snail before it becomes more widespread. Further spread, for example into the irrigated rice-production area of Ahero (see Yamane, 2019), at the edge of Lake Victoria could have huge consequences. Were $P$. canaliculata to enter and persist in Lake Victoria, its spread into surrounding rice production in Tanzania and Uganda could be rapid, and ongoing dissemination throughout catchments and into major river systems such as the White Nile could be disastrous for the region.

\subsection{Modelling the distribution of invasive apple snail}

Climate models applied to the potential expansion of the species, inferred high colonization ability of many non-infested areas of the world (Baker, 1998), facilitated by the increased activity of the snails at higher temperatures (Heiler et al., 2008).

A number of models have been developed to describe the potential range and performance of $P$. canaliculata in different geographic locations, using various approaches and combinations of parameters to predict distribution, density and population dynamics (e.g. Baker, 1998; EFSA Panel on Plant Health, 2012; Lei et al., 2017; Reilly, 2017). Distribution models have also been developed for additional invasive apple snails including the congeneric species P. maculata (e.g. Byers et al., 2013; Barbitta et al., 2020).

Several studies implement correlative habitat modelling approaches (e.g. CLIMEX and MaxEnt) to infer potential range and suitability of specific regions to $P$. canaliculata including South-east Asia and Australia (Baker, 1998), Europe (EFSA Panel on Plant Health, 2012) and Florida (Reilly, 2017). Lei et al. (2017) use multi species distribution model (SDM)-based ensemble forecasting to predict the potential distribution of $P$. canaliculata worldwide under recent conditions (see Fig. 4) and future climate change scenarios. These models suggest that much of rice production in eastern Africa (and SSA more broadly) is likely to be under threat from the snail under current climatic conditions, including all areas of Tanzania, the major producer in the region. Mwea, Kenya looks to be nearing the edge of the climate suitability envelope, though field surveys suggest that the area is hosting a healthy population of $P$. canaliculata and future surveys would be useful to determine long-term population persistence. Eastern areas of Ethiopia including much of Somali appear less at risk, although rice grown in this region is typically irrigated and it is unclear if this factor would make Somali rice paddies viable sites for $P$. canaliculata to persist as water availability was not included in the model. Climate change scenarios indicate that eastern Africa is likely to become more suitable for $P$. canaliculata over the next 30-60 years, particularly so under Canadian Centre 
for Climate Modelling and Analysis climate scenarios compared with CSIRO (Commonwealth Scientific and Industrial Research Organization) scenarios.

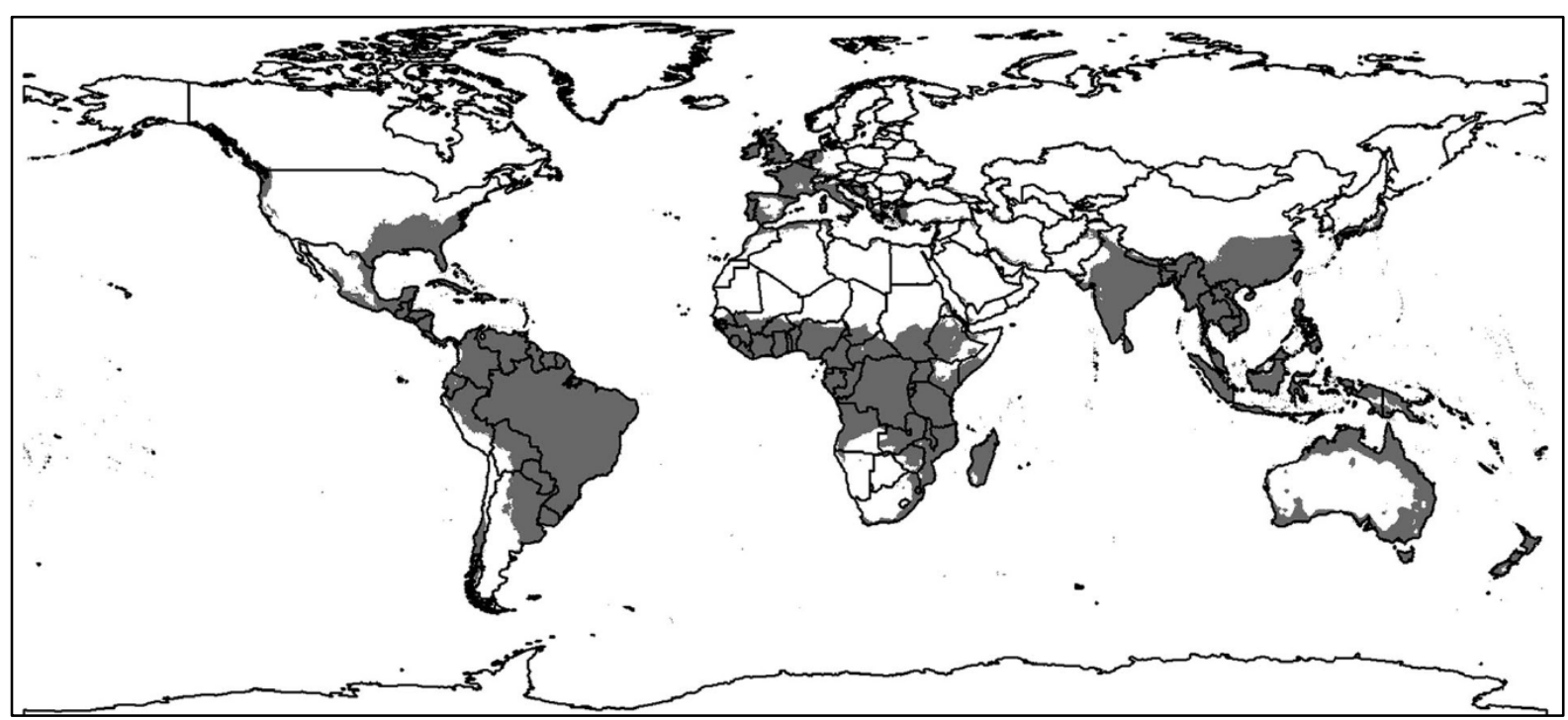

Fig. 4. Current climatically suitable habitats for Pomacea canaliculata (grey). Reproduced from: Lei et al. (2017).

Mechanistic niche models incorporating the effects of various environmental variables on certain components of snail performance have also been used. For example: (i) the effects of fallow periods and biocontrol agents on population dynamics of $P$. canaliculata were modelled by Halwart et al. (2006); (ii) a simple degree-day model for maturity was developed by Zhou et al. (2003) to model the snail's spread in China using air temperatures; and (iii) a population dynamics model was developed to model areas of potential establishment and likely high density 'hot spots' in Europe by EFSA Panel on Plant Health (2013).Temperature is a key environmental factor for $P$. canaliculata performance and survival and Gilioli et al. (2017) present a temperature-dependent physiologically based model for the snail to predict population density and associated impacts in different environments with high spatial resolution. Both air and water temperatures are considered, for the egg and aquatic stages, respectively. The model is validated against known distribution data for South America and Japan and produces realistic patterns of reproduction, development and mortality according to conditions in different regions and climates. The model also demonstrates that $P$. canaliculata will use two different reproductive strategies (semelparity and iteroparity) depending on conditions, a plasticity which may help to explain the snail's invasive success across a wide range of habitats and climates. $P$. canaliculata is also reported to have a higher tolerance to both low and high temperatures than other introduced Pomacea and this capacity is likely to be another key factor in explaining the invasiveness of this species (Mu et al., 2015; Matsukura et al., 2016). According to the model of Gilioli et al. (2017), within the potential areas of establishment, $P$. canaliculata population density may vary significantly and determining potential snail 'hot spots' would be valuable to guide management. A mechanistic, physiologically based model to determine $P$. canaliculata population dynamics for 'at-risk' regions in eastern Africa (and SSA more broadly), potentially in combination with correlative climatic modelling for the region could be extremely useful to identify areas at significant risk of crop losses, to guide management approaches and timings and identify potential corridors 
of spread. Higher resolution modelling would also allow for improved crop loss estimates to be calculated, with highest losses expected in hot spots at particular risk from $P$. canaliculata coinciding with important crop growing habitats.

\subsection{Environmental suitability for invasive apple snail colonization}

Kwong et al. (2008) summarize the key factors likely to influence freshwater gastropod distribution as: i) biological (food, competition, predation); (ii) chemical and physical (calcium, salinity, flooding, current speed, substratum, temperature, desiccation, geographic barrier); or (iii) cultural (aquarium trade). In relation to $P$. canaliculata, limiting factors are typically considered to be primarily chemical and physical as evidence that competition or predation can effectively control the species is lacking (Kwong et al., 2008).

In an assessment of the relative importance of environmental factors and geographical isolation on the distribution of $P$. canaliculata in Hong Kong, Kwong et al. (2008) found that water with high total phosphate and alkalinity was typical of sites inhabited by $P$. canaliculata. This is different from the situation in its home range, with saline, alkaline waters forming a physiological barrier limiting the snail's expansion in Buenos Aires (Martín et al., 2001) although the snail was also found at low density in streams with relatively low alkalinity and dissolved mineral concentration. Drainage channels with cement lining and high wet-season water velocity were free from the snail. Sites on Lantau Island thought suitable for the snail remained free, likely due to geographic isolation from other populations.

Temperature is a primary factor in determining environmental suitability for $P$. canaliculata (and related snail species), with all aspects of Pomacea biology highly dependent on temperature, including feeding, growth, sexual activity and egg laying (Gilioli et al., 2017). P. canaliculata does, however, appear to have a higher resistance to both higher and lower temperatures than congeneric species (Gilioli et al., 2017), with resistance to higher temperatures stronger than resistance to lower temperatures (Lei et al., 2017). Broad climatic requirements for Ampullariidae survival are estimated to include an annual average minimum temperature above $10^{\circ} \mathrm{C}$ and $600 \mathrm{~mm}$ annual rainfall (Berthold, 1991), although with high uncertainty for Pomacea species (EFSA et al., 2020). In temperate Japan, P. canaliculata develops cold hardiness prior to winter (Wada and Matsukura, 2007), but does not seem to tolerate freezing (Matsukura et al., 2009). Overwintering survival in water with low temperatures of $2-8^{\circ} \mathrm{C}$ was determined by $\mathrm{pH}$, dissolved oxygen and water depth in water channels in the northernmost population of $P$. canaliculata in Japan (Ito, 2002). Over winter snails can remain inactive for several months, but can respond rapidly to increases in temperature and the onset of more favourable conditions (EFSA et al., 2020). Wada and Matsukura (2007) demonstrated that $P$. canaliculata show enhanced cold hardiness after a period of acclimation and that cold-tolerant snails can better withstand desiccation than coldintolerant snails without cold acclimation. High temperatures can also have a detrimental effect on $P$. canaliculata, with egg viability at $30^{\circ} \mathrm{C}$ very low and snails reared at $35^{\circ} \mathrm{C}$ unable to produce eggs; snail survival was found to be highest at $15-20^{\circ} \mathrm{C}$ where no mortality was observed over 2 years of laboratory rearing (Seuffert and Martin, 2010). P. canaliculata is able to reproduce continuously, reaches maturity sooner, can complete more generations per year and maintain high populations of juvenile and mature snails year-round in tropical regions (Gilioli et al., 2017), going some way to explaining the huge impacts the snail has had in tropical rice-growing parts of Asia. Winter mortality in temperate regions is considered an 
important factor in the population dynamics of the snail, however, during the summer months temperate thermal regimes may allow maturation almost as fast as those in tropical climates (possibly due to detrimentally high temperatures in the latter). Results of temperaturedependent physiologically based modelling by Gilioli et al. (2017) suggest that in temperate climates $P$. canaliculata eggs would fail to survive winter. The authors suggest that in these regions, managers should aim to manage snails late in winter (e.g. hand-pick, till or manage water level), when population densities are at a minimum but before water temperature rises above $15^{\circ} \mathrm{C}$ and the snails reactivate.

\section{Impacts of apple snail on rice and other socio- economic variables}

\subsection{Documented global impacts}

$P$. canaliculata feeds on a wide range of aquatic plants of economic value but the greatest damage by far has occurred in irrigated rice ecosystems, which provide an ideal environment for the dispersal and growth of the snail (Halwart, 1994; Joshi et al., 2003; R.E. Joshi, 2005). In the Philippines, snail production was promoted by the government as a national livelihood programme to increase the protein intake of low-income Filipino farmers and as an additional source of income (Ang, 1984; Adalla and Rejesus, 1989), but their associated health hazards caused demand to drop and cultures to be disposed of without precautions, such that rice fields were soon invaded. Economic losses in the Philippines accumulated over roughly the first decade of invasion (early 1980s to mid-1990s) were estimated to be up to US\$1.2 billion (Naylor, 1996; Sin, 2003), even without taking into account the non-crop damage to human health and natural ecosystems, with farmers spending US\$10 million on pesticides in a 3-year period alone (Anderson, 1993). The expenditure for synthetic molluscicides in 1998 in the Philippines was estimated at US\$2.4 million (Dancel and Joshi, 2000). In 1993, Filipino farmers spent about US\$9/ha for apple snail management (Medrano et al., 1993). Even with proper use of registered commercial molluscicides, the cost is approximately US $\$ 23 /$ ha, with a countrywide expenditure of US\$7.4 million/year and still the snails remain a major biotic constraint in all rice-growing regions of the Philippines (Joshi et al., 2001), despite claims that infestations had decreased thanks to integrated management approaches (Cagauan and Joshi, 2003). In 2003, of about 3 million ha of rice fields in the Philippines 1.4 million ha were still infested (Adalla and Magsino, 2006).

Similarly, in Taiwan, loss of rice was estimated at US\$2.7 million in 1982, which increased rapidly to US\$30.9 million by 1986 (Mochida, 1991). Between 1982 and 1990, annual expenditure on molluscicides was US $\$ 1$ million but in 2002-2003 budget cuts saw a reduction in this number to US\$170,000-300,000 (Cheng and Kao, 2006). Annual figures of US\$200 million and US\$175.6 million have been given for costs of damage in the 'agricultural and ecological environment', by Cheng and Kao (2006) and Yang et al. (2006), respectively.

In Japan, control of the snail on just 176 ha cost US\$64,385 (Mochida, 1991). The first record of rice damage caused by $P$. canaliculata was reported in 1984 (Yusa and Wada, 1999) and that same year it was designated as a quarantine pest by the Japanese Government. Since then, its distribution has gradually expanded such that in 1998 it was in 28 prefectures throughout south and central Japan (Wada, 2006). By 2004, it had infested 770,000 ha of rice fields, about $60 \%$ of this area being in Kyushu (Wada, 2006). The level of damage may have stopped increasing during the 1990s because of the application of various control methods. 
However, $P$. canaliculata is still a serious pest in areas of Kyushu where very young seedlings are transplanted and where it rains heavily during the transplanting season. In addition, the presence of the snail is a constraint in promoting direct seeding in Kyushu (Wada, 1997, 2006; Yusa and Wada, 1999).

Nghiem et al. (2013) estimated the total annual loss caused by Pomacea snails to rice in Thailand and Vietnam as US $\$ 74.8$ million, based on: the average gross production value of rice over the previous decade, the proportion of surveyed locations with serious infestations of snails (density of one snail $/ \mathrm{m}^{2}$ or more; $19 \%$ and $90 \%$, for Thailand and Vietnam, respectively), and a damage ratio of $0.7 \%$. Engelhardt and Ritchie (2001) suggested that estimates were likely to underrepresent the true cost as they failed to include human health and environmental impacts (e.g. impacts on wetland ecosystem services, reduced biodiversity and biomass of aquatic plants affecting the nutrient retention capacities and economic/cultural value of wetlands).

In mainland China, $P$. canaliculata was first recorded in Guangdong province in 1981 and by 1988 the damaged area had grown to 9,130,000 ha in 37 counties in the province (Wu and Xie, 2006). Now much more widespread in China (Lv et al., 2011), damage has been proportional to levels of direct-seeded rice but economic costs are not readily available.

Pomacea spp. are also considered a serious rice pest in Malaysia and Indonesia and require regular interventions but yield losses and control expenses in these countries have not been documented (Nghiem et al., 2013).

Snails spread rapidly through waterways and irrigation canals, eventually infesting rice fields (Cowie, 1995b; FAO, 1998) which provide an ideal habitat; the snails are voracious, nocturnal feeders and attack young succulent plants such as newly transplanted rice seedlings and emerging tillers as well as weeds, quickly increasing their population and causing devastating losses (FAO, 1998). If the rice field is flooded, the germinated seeds are consumed first, with the early seedling phase also proving most vulnerable to attack (in the first 4 weeks when directly seeded or 2 weeks when transplanted) (Halwart, 1994); snails will eat the aerial part of the seedlings, severing the plants just above ground level and consuming the stem and leaves. Snails under $1.5 \mathrm{~cm}$ in diameter do not attack rice plants, however, larger snails can destroy 7-24 seedlings/day. A reduced rice plant population is an indicator of high infestation (EFSA et al., 2020) and missing plants and floating leaf fragments of the rice plants characterize damage to newly transplanted rice (Joshi et al., 2002). The extent of damage to rice depends on snail size, its density, and the growth stage of the rice plant (Morallo-Rejesus et al., 1989). A density of three snails $/ \mathrm{m}^{2}$ causes significant yield loss, with much greater damage being inflicted on direct-seeded rice and young seedlings transplanted at 18-21 days after sowing (Litsinger and Estano, 1993).

Joshi et al. (2002) reported that snails of $40 \mathrm{~mm}$ were generally the most destructive size, irrespective of rice establishment method used, causing $100 \%$ destruction of rice seedlings in the germinating stage and at least $20 \%$ in transplanted seedlings. In Malaysia, P. canaliculata and P. maculata are serious pests of rice agriculture (Salleh et al., 2012; Arfan et al., 2014, 2016), causing losses of approximately RM82 (US\$20) million (2010) in rice fields in the peninsula (Yahaya et al., 2017).

The economic costs associated with Pomacea species arise both directly, through the destruction of rice and other crop plants by the snails, as well as indirectly, through payment for pesticides and labour costs for physical removal of the snails. 
In Hawaii, $P$. canaliculata has cultural and lifestyle impacts. Taro is a spiritually important crop, especially for native Hawaiians, and farming taro is an important lifestyle. Taro is also important educationally, as students, teachers and community groups use irrigated taro systems to explore topics in art, science, mathematics, health, capacity building and Hawaiian culture. The introduction of $P$. canaliculata and the subsequent impacts on taro growing threaten all of these activities (Levin, 2006; Levin et al., 2006) as it will feed on all parts of taro plants, including corms, stems and leaves.

The farm value of taro was reported as US\$2.7 million, but as a result of losses of $18-25 \%$ suffered over the year by snail damage, it dropped to US\$2.2 million (Levin, 2006).

\subsection{Prediction of economic and yield loss due to invasive apple snail in East Africa}

There are many variables that may influence invasive Pomacea population dynamics and associated crop losses experienced by rice growers, including the following: (i) rice variety; (ii) method of propagation (direct seeding vs transplanted); (iii) irrigation approach (irrigated vs rainfed); (iv) climatic conditions (e.g. tropical, temperate, highland, lowland, coastal); (v) water levels through the season; (vi) local management approaches and cooperation between growers; (vii) affordability and availability of labour for snail management; (viii) affordability and availability of molluscicides; (ix) timing of control implementation (e.g. rapid early eradication vs management of widespread and high density infestation); (x) age/size distribution of snails (larger snails are more damaging); (xi) role of natural enemies/biocontrols (e.g. fish, birds); (xii) availability of additional/alternative food sources across the season; (xiii) connectivity of rice paddies (e.g. along a river catchment or across a floodplain); and (xiv) implementation of containment measures to limit movement within/between regions.

To give an indication of the scale of losses that could be suffered by rice growers given continued population-density increase and spread both within Kenya and beyond to neighbouring countries, invasion scenarios and associated economic losses over a timeframe of roughly a decade from first arrival are provided. For Kenya this period could feasibly cover a decade from 2020 as $P$. canaliculata is now present with potential to become well established and spread. However, for the other eastern African countries assessed this will depend on how well and for how long they are able to exclude the pest and remain free from establishment and associated impacts. The period of a decade is a rough approximation, guided by the scale of loss to $P$. canaliculata by rice farmers in the Philippines indicated by Naylor (1996) for 1990, following the arrival of the species in the country in 1982. Examples from Asia indicate that once present in a country, Pomacea can spread quite rapidly (particularly if facilitated by intentional movement), and entry into waterways and irrigation systems can allow rapid and widespread infestation of rice paddies. Some examples of rapid spread have been reported for important rice-growing countries in Asia: (i) in Taiwan 2\% of the rice area was infested in 1982 increasing to $28 \%$ of the rice area by 1986; (ii) by 1986, 34 of 47 rice-growing districts in Japan were infested by Pomacea following its introduction in 1981; (iii) in the Philippines, the proportion of wet rice area infested rose from below $3 \%$ in 1982 to $\sim 15 \%$ (of > 3.44 million ha) by 1991; and (iv) within 5 years of its introduction to Vietnam, Pomacea snail infestations were reported in every rice-growing province and threequarters of rice-growing districts (Naylor, 1996).

As described in Naylor (1996) for the Philippines, losses to apple snail can be highly variable (for a variety of reasons, some of which are described above) but may range from $<5 \%$ to 
$100 \%$ depending on the region and severity of snail infestation. The stage of rice attacked is particularly important, with rice seedlings most vulnerable up to 2 weeks after being transplanted or up to 4 weeks after direct seeding. In uncontrolled fields, experimental data described indicates that damage to rice seedlings at the germinating stage can be as high as $100 \%$, rather than an average of $20 \%$ at the transplanting stage (Naylor, 1996). Sin (2003) found at a density of three snails $/ \mathrm{m}^{2}$ in typical paddy-water depths damage to transplanted rice was high but lessened with increasing planting age, however, direct-seeded rice was extremely susceptible to the snail even at one snail $/ \mathrm{m}^{2}$; by contrast at zero water depth the snail did not cause significant damage to rice. Direct seeding versus transplanted rice seedlings (and at what age) and depth of water, particularly early in the growing season, are important considerations for rice farmers seeking to manage losses in areas affected by invasive Pomacea. Rice crop losses exceeding 90\% are also reported in Naylor (1996) given a snail density of eight snails $/ \mathrm{m}^{2}$, in an experimental setting. This would be a very high density of GAS with 1-5 snails $/ \mathrm{m}^{2}$ more typical in highly infested fields in the Philippines, although peak densities in low-lying regions could reach $\sim 150$ snails $/ \mathrm{m}^{2}$ (Halwart, 1994). Some examples of Pomacea-associated costs are provided in Section 2.1. However, despite the relatively long and damaging history in Asia, detailed reports of economic losses associated with the snail's invasion are quite limited. One of the most widely quoted is the analysis for the Philippines by Naylor (1996) mentioned above, cited for example in the assessment of invasive species impacts in South-east Asia by Nghiem et al. (2013). Following from Naylor (1996) for direct-seeded paddy, at the level of one snail $/ \mathrm{m}^{2}$ average production losses of $20 \%$ across affected rice-growing areas, without control measures or replanting, are feasible, and used here to calculate potential economic costs for eastern African countries (with some areas expected to lose more and others less depending on specific snail density and other key parameters as described above). Where snail control measures (hand-picking and molluscicide application) and replanting are undertaken, rice losses are reduced to 5-8\% (estimated from loss calculations in Naylor, 1996), but the additional costs of these actions are $6-11 \%$ of the affected crop value in well and poorly controlled regions, respectively. Combined, the cost of apple snails to farmers when management and replanting are undertaken is estimated at $11-19 \%$ of the affected rice-production value ('Lower' and 'Upper' loss values, respectively, in Table 1). This scale of costs and economic losses will vary by region, with differences in the availability and price of molluscicides, labour and rice seed/seedlings (compared with the Philippines and between regions in the study area), but the general management approaches available are similar and the magnitude of costs indicative. It is assumed that labour costs across the predominantly smallholder-farmer production system are low, as preventative and corrective control measures (such as handpicking and repeated replanting) can be labour intensive and may not be feasible in countries where labour costs are high (Halwart, 1994).

The specific prevalence and impact of apple snail is likely to vary considerably over the study area, with differing agroecological conditions across eastern Africa and variations in altitude, rainfall and temperatures between rice-growing regions and across seasons. However, the figures provided may be useful in planning and developing loss mitigation strategies. Broadscale modelling of environmental suitability for $P$. canaliculata has been carried out, for example by Lei et al. (2017) using SDM ensemble forecasting, indicating that much of eastern Africa (along with western and central SSA) is climatically suitable for $P$. canaliculata, increasingly so with climate change. Physiologically based demographic models have also been developed (e.g. Gilioli et al., 2017) which can be used to better understand population 
dynamics and potential high-density 'hot spots' (which could be valuable to guide management efforts in eastern Africa) and these are discussed further in the modelling section (Section 1.7). It is apparent that temperature can be limiting for $P$. canaliculata distribution, with increased winter mortality in temperate regions (potentially crucial in population dynamics in Japan) and slower development to maturity compared with populations in tropical regions. However, lifespan can be longer in temperate climates and in some cases temperate summers may allow developmental rates close to those in tropical climates, possibly due to the detrimental effects of temperatures exceeding $30^{\circ} \mathrm{C}$ in the latter (Gilioli et al., 2017). As such, despite ecoclimatic variations across the study area, for economic loss calculations the assessed 'at-risk' regions in eastern Africa fall within the climatic suitability envelope indicated by Lei et al. (2017) and the impact of $P$. canaliculata in each region is calculated at the same rate. Benefits are not considered here but are covered in other sections and thought to be greatly outweighed by the snail's costs.

In Kenya, significant infestations of $P$. canaliculata have been observed in Mwea and spread to other regions is perhaps inevitable given the water connectivities and extensive reproduction indicated by widespread presence of egg masses (Buddie et al., 2021). In addition, Mwea, located in the tropical highlands, is the primary rice-growing area in the country and in this region alone, $P$. canaliculata has the potential to affect approximately $80 \%$ of Kenya's rice production (Samejima et al., 2020) and it is this figure that is used in calculating potential losses. This level of loss would still require long-term measures to contain the pest and prevent movement of the snail to other rice-production areas. Kenya is one of many SSA countries with a growing demand for rice, relying on imports to meet requirements and seeking to increase rice production and self-sufficiency (Atera et al., 2018). Additional considerations must now be addressed if $P$. canaliculata cannot be eradicated and must be managed. For example: (i) With expansion of rice production, what effect would an increase in rice irrigation have on the survival and spread of the snail (reduced drought period, water network connectivity)?; (ii) Would multiple croppings per year bolster snail populations (no fallow period)?; and (iii) What rice varieties should be grown and would direct seeding be viable or would transplanted rice suffer reduced losses?

Tanzania is a major rice-growing country, producing an average of around 3 million t/year of paddy rice (2014-2018; approaching 3.5 million t in both 2018 and 2019 FAOSTAT database, (FAO 2019)) and one of few SSA countries approaching rice self-sufficiency (along with Madagascar and Mali) (Tadesse et al., 2019). Around half of production is concentrated in Morogoro, Shinyanga and Mwanza, with Mbeya, Rukwa and Tabora also important riceproducing regions (Tanzania Ministry of Agriculture, 2009; Wilson and Lewis, 2005). Rice production is carried out across the country, unlike in Kenya, where most production is focused in a single region, Mwea. To estimate the proportion of at-risk production for calculating potential losses, a scenario in which widespread snail infestation of the three key production areas (Morogoro, Shinyanga and Mwanza) - which are also the most proximate to Kenya - is envisaged, with $50 \%$ of Tanzania's rice production affected.

Much of Uganda has good potential for rice growing, however, up to around two-thirds of rice is produced in Eastern Uganda (Nanfumba et al., 2013), particularly the low-lying wetlands in the Lake Kyoga catchment and foothills of Mount Elgon. For the calculation of losses, a scenario in which the primary growing region (and nearest to Kenya) of Buginyanya in Eastern Uganda suffers widespread snail infestation is envisaged, affecting half of the country's rice production (Uganda Bureau of Statistics, 2020). 
In Ethiopia, the dominant region for rice production is Amhara to the north of the country, with as much as three-quarters of the country's production coming from the area (Tsega et al., 2013; Tadesse et al., 2019). Other production areas of note include Oromia, Tigray, Somali, Benishangul Gumuz and Southern Nations, Nationalities, and Peoples' Region (SNNPR). The vast majority of national production is rainfed (both lowland and upland), with limited irrigated rice. Rice is a relatively recent addition to the cropping systems of Ethiopia and to date production increases have been outpaced by increasing demand, with self-sufficiency in the crop dropping as low as 30\% (Tadesse et al., 2019). Ethiopia is, however, thought to have extensive areas with suitable agroecology for rice production, with as much as 30 million ha suitable for rainfed growing and 3.7 million ha for irrigated rice production (Tadesse et al., 2019). There is a drive to substantially increase rice production in the country, with the crop considered strategically important for food security, to reduce poverty and to provide income for farmers (Tadesse et al., 2019). Given the great distance of Ethiopia from Mwea and potential to limit incursions, with the key production area Amhara further north still, an economic loss scenario is presented for Ethiopia with widespread infestation in the lowland rainfed rice-growing district of SNNPR, bordering Kenya and producing an estimated $5 \%$ of Ethiopia's rice (Tsega et al., 2013).

The losses provided in Table 1 are calculated using average rice-production levels for 5 years to 2018 (where available; fewer years for data-limited countries). These data are used because they represent the recent/current production capacity for each country, however, as net rice importers each of these countries is striving to become more self-sufficient in rice production (Tadesse et al., 2019).

Table 1. Potential annual economic costs of $P$. canaliculata to rice producers in eastern Africa approximately 10 years after introduction to a country for a scenario with specific rice-production areas (provided in text) affected. Losses are provided for no management, good control ('Lower') and poor control ('Upper').

\begin{tabular}{|c|c|c|c|c|c|c|}
\hline \multirow[b]{2}{*}{ Country } & \multirow{2}{*}{$\begin{array}{l}\text { Proportion } \\
\text { of national } \\
\text { production } \\
\text { at risk }\end{array}$} & \multirow{2}{*}{$\begin{array}{c}\text { National } \\
\text { productio } \\
\mathrm{n}(\mathrm{t})(5- \\
\text { year } \\
\text { average } \\
2014- \\
2018)\end{array}$} & \multirow{2}{*}{$\begin{array}{c}\text { Crop } \\
\text { value } \\
\text { (US\$/t) } \\
\text { (average } \\
2014-2018 \\
\text { where } \\
\text { available) }\end{array}$} & \multirow{2}{*}{$\begin{array}{c}\text { Projected } \\
\text { cost without } \\
\text { snail control } \\
\text { (US\$) } \\
{[\sim 10 \text { years }]}\end{array}$} & \multicolumn{2}{|c|}{$\begin{array}{l}\text { Projected cost with snail } \\
\text { control (US\$) } \\
{[\sim 10 \text { years }]}\end{array}$} \\
\hline & & & & & Lower & Upper \\
\hline Ethiopia & 0.05 & 137,080 & 414 & 568,086 & 312,447 & 539,682 \\
\hline Kenya & 0.8 & 108,487 & 558 & $9,692,698$ & $5,330,984$ & $9,208,063$ \\
\hline Tanzania & 0.5 & $2,900,801$ & 347 & $100,764,157$ & $55,420,287$ & $95,725,950$ \\
\hline Uganda $^{a}$ & 0.5 & 248,848 & 440 & $10,950,852$ & $6,022,968$ & $10,403,309$ \\
\hline
\end{tabular}

a Uganda crop value is estimated from the average of Ethiopia, Kenya and Tanzania.

A targeted expansion is driven by the Coalition for African Rice Development (CARD) which seeks to greatly increase rice production in SSA to fulfil the ever-growing demand for this staple crop across the region (see Section 1.1). The major expansion in rice production underway across SSA, but particularly relevant to eastern Africa for this assessment, emphasizes the growing importance of rice both for food security and as a cash crop, but also the increasing risk of and potential losses to key pests such as apple snail. Present and near- 
term losses are likely to be important, particularly for Kenya where $P$. canaliculata has a foothold and is already affecting production, but without efforts to manage populations and contain the snail's spread, future losses across the region could be much greater, as has been observed in parts Asia with a long history of apple snail invasion and associated impacts across a huge scale of rice production. Tanzania particularly is a large-scale rice producer in the region and could suffer costly losses and potential food insecurity under widespread snail infestation. The losses to $P$. canaliculata may also be additional to those for other pests and diseases and will primarily affect smallholder farmers who are responsible for the bulk of rice production and depend on the crop as a staple and for sale to market. $P$. canaliculata impacts on rice are expected to be the most important for the areas assessed, but other crops grown in the paddy-type environment may also be at risk, as seen with taro in Hawaii (Halwart, 1994). Impacts on other crops would result in economic losses additional to those provided for rice. The estimates provided also do not account for human health and ecosystem impacts, each of which could be significant but difficult to quantify. Improved modelling specific to eastern Africa (or SSA) to provide higher resolution mapping of at-risk and hot spot areas for $P$. canaliculata, ideally combined with field studies to 'ground truth' the models would enable more accurate assessments of crop loss and risk.

To date, delimiting surveys in Kenya indicate that $P$. canaliculata is present only in Mwea, however, this is the major rice-production scheme in the country. If practicable, containment would be desirable for rice production across the region, with measures implemented to prevent the movement of snails along water courses or via infested plant materials essential. To fundamentally halt the spread of and losses to $P$. canaliculata across the region (at least until a next introduction event), eradication of the population(s) in Mwea would be extremely advantageous. This approach can be achievable, particularly if enacted swiftly and before it becomes too widespread, as has been demonstrated at various scales in Europe against Pomacea spp. For example eradication of Pomacea spp. is thought to have been achieved in an artificial pond in Switzerland, an area of rice fields in Girona, Spain and also in the French municipality of Fréjus (EFSA et al., 2020). The challenge of attempted eradication of Pomacea spp. once well established and spreading, however, can be significant. Pomacea spp. of the 'canaliculata complex' discovered in rice paddies in the Ebro Delta, Catalonia in Spain in 2009 have been under ongoing eradication efforts, however, are spreading along the riverbeds of the Ebro river (EFSA et al., 2020). Some control and limitation of agricultural impact has been achieved, but at a cost of $€ 5.3$ million in the period 2010-2012 and with a further $€ 5$ million allocated by the Government of Catalonia for the period 2014-2020 (Bertolero and Navarro, 2018). If feasible, rapid investment in eradication (or effective control and containment) in Mwea and surrounds could significantly reduce longer term losses across the region. As described in Section 1.6, spread into the rice-production area of Ahero, for example, could lead to infestation of Lake Victoria, its surrounding rice-production regions and beyond via river catchments including major tributaries such as the White Nile, with major implications for the region.

In the broader context of SSA rice production, losses in eastern Africa could be significant and a risk to food security and income. However, strong measures must also be implemented to prevent movement across the continent to the tropical and subtropical rice-growing regions of West Africa, where production can be on a huge scale (e.g. Nigeria $\sim 8$ million t/year of rice paddy), conditions may be even more conducive to snail establishment and spread and potential impacts on food security and farmer income could be considerable. 


\subsection{Potential impacts of invasive apple snail on trade}

Three main value chains can be identified within the Kenyan rice sector (i) the vertically integrated large farm chain; (ii) the highly concentrated chain on the National Irrigation Board (NIB) schemes; and (iii) the traditional market value chain of the non-NIB irrigated production and rainfed producers.

Kenya is a member of both the East African Community and COMESA (the Common Market for Eastern and Southern Africa) regional trading blocs. It is bound by the common tariffs that apply to the member states of these trading blocs but there is a lot of informal cross-border trade with neighbouring countries. There is also rice seed movement across the borders which may not have undergone formal certification processes that could be detrimental to the rice subsector development.

Plants other than rice grown in the paddy environment or in proximity to $P$. canaliculata populations may also be at risk of harbouring snails which could then be moved around within the country or across national borders. An example of this type of movement occurred when water spinach (Ipomoea aquatica) imported to Malaysia from Thailand was found to be contaminated with young snails, which led to a temporary government ban on the import of vegetables into Malaysia from Thailand (Naylor, 1996; Halwart, 1994). Pomacea spp. are classified as quarantine pests in the European Union (EU), and the trade of aquatic aquarium plants (considered the main potential pathway of spread) is regulated (EFSA et al., 2020). To avoid the risk of produce export bans and to prevent the spread of $P$. canaliculata to currently unaffected trading countries or areas (with the associated responsibility for the introduction of a damaging invasive pest), measures may be required to ensure crops traded out of Mwea are snail free, for example with certified 'clean' production areas or suitable treatment of plant material to be traded. Plant material grown to be propagated elsewhere would be a particular risk, as is the movement of machinery between rice-growing schemes. Certainly, an assessment of crops grown and traded out of Mwea would be valuable to establish risk pathways. There is therefore need to have quarantine regulation, traceability and inspection rules by all the partner states.

\section{Control methods}

Any attempts at management should be grounded in a clear understanding of the identity and biology of the pest species so that control measures can be more reliably developed and quarantine efforts more targeted (Eversole, 1992; Halwart, 1994; Cowie, 2002). The molecular diagnosis of $P$. canaliculata in Kenya provides crucial confirmation and should highlight the need for rapid response and early intervention to halt the spread and monitor the extent of the invasion. $P$. canaliculata is the most widespread and damaging species of Pomacea introduced around the world and as such, the bulk of the literature on management of apple snail pests undoubtedly refers to this species. However, because of the past confusion regarding the identities of the species introduced to Asia and elsewhere, some of the information purportedly relating to $P$. canaliculata may relate to either or both $P$. canaliculata and P. maculata (CABI, 2020).

In the main, eradication of invasive snails has proved extremely difficult (Cowie, 2011) and is only likely to be achievable with a rapid response in the very early stages of invasion and when the infestation is highly localized (Cowie, 2002). The consequences of delayed intervention have been evident in many countries: in Vietnam it took only 5 years from initial introduction 
for Pomacea spp. (probably both $P$. canaliculata and P. maculata (Hayes et al., 2008)) spreading to every rice-growing province of the country (Naylor, 1996). Similarly, in Cambodia, recommendations to eradicate the snails from a few isolated areas were not headed in time and they subsequently spread to at least ten provinces (Preap et al., 2006).

Economic incentives promoting the use of snails as a protein-rich food source have been controversial (Levin, 2006) and have the potential to precipitate further introductions and ultimately exacerbate the problem.

Various management measures have been trialled to control the impact and spread of invasive Pomacea species around the world (Joshi et al., 2003; R.C. Joshi, 2005a) and in order to facilitate best practice in Kenya, regulations need to be in place to facilitate coordinated action and raise awareness of the threat they pose. Farmers in Asia have tended to base their actions on past experience and the potential damage caused by $P$. canaliculata in rice has been shown to be closely linked to water depth, seedling age and pest density, in decreasing order of importance (Teo, 2003). Therefore appropriate agricultural practice will play a key role in limiting impact.

The challenge will be to prevent $P$. canaliculata damage through low-cost, technically efficacious and environmentally sustainable management options (R.C. Joshi, 2005a).

Measures are needed in terms of both regulation and farmer/public education to reduce the negative consequences, safeguard yields and income for rice farmers, prevent further introductions and prevent spread across the African rice belt. The following sections provide a synthesis of control methods from around the world.

\subsection{Chemical control}

For many countries detecting $P$. canaliculata invasion, the first responses have tended to be drastic and involved excessive spraying of indiscriminate molluscicides (many of them banned) with unwanted side effects (traditional pest resistance, elimination of non-target beneficial animals such as fish and frogs, phytosanitary issues, phytotoxicity, modification of size distribution of the population favouring larger individuals and risks to human health) (Ochoa Chumaña and García Onofre, 2012; Horgan, 2017). Wetlands are often located close to or even connected to rice fields and this means that snail control efforts that are focused only on rice fields are likely to be short lived, as new snails enter the fields from nearby wetlands through irrigation canals and during floods (Carlsson et al., 2004b).

None the less, in some countries, the application of chemical molluscicides remains one of the most utilized methods of snail control (Khay et al., 2018).

This section consolidates the literature on chemical control of invasive apple snails, however, many pesticides historically used are either no longer recommended or indeed discontinued. Before using a molluscicide product, users should ensure the product is registered with the national regulatory body. Regulatory authorities should be consulted before implementing snail control programmes. There are no synthetic molluscicides registered for use in Kenya.

Historically, snail control has relied primarily on a single compound, namely, niclosamide World Health Organization (WHO) classification $U$, unlikely to present acute hazard). Currently, it is the only compound recommended by WHO Pesticide Evaluation Scheme (WHOPES) for use as a molluscicide globally because of its low toxicity to mammals and low concerns of pesticide residue, however, it has been found to be toxic to fish and other aquatic animals. It is not registered for use in Kenya (PCPB, 2021). Niclosamide was selected as a 
molluscicide in the 1950s after screening well over 20,000 compounds for toxicity against the schistosome-transmitting snail Biomphalaria glabrata (Andrews et al., 1983). Application in rice fields was recommended immediately after transplanting rice (Dela Cruz and Joshi, 2001). Joshi et al. (2004) observed the detrimental effects of niclosamide $250 \mathrm{EC}$ at pre-seeding in direct-seeded rice culture. Seedlings treated with niclosamide $250 \mathrm{EC}$ had low and uneven emergence and were stunted. Uneven crop establishment also exposed the seedlings to invasive apple snails' damage for a much longer time.

Endosulfan (WHO Class II, moderately hazardous), fentin acetate (WHO Class II, moderately hazardous) and the now obsolete calcium cyanamide have also been used (Halwart, 1994; Dela Cruz and Joshi, 2001). In Thailand, apple snail has been effectively controlled using copper sulfate (WHO Class II). Wada (2004) reported use of metaldehyde (WHO Class II) for direct-seeded rice fields in the Philippines.

In the Philippines, where Pomacea are widely considered to be the most serious rice pest, about $40 \%$ of farmers applied pesticides for control (Revillia et al., 1991; Ketelaar, 1993). However, a number of species are also reportedly suffering from the direct impacts of molluscicides employed to reduce gastropod species, which are vectors of bilharzia (Kristensen and Brown, 1999).

In Malaysia, synthetic molluscicides have been used to try to control $P$. canaliculata without much success. A study by Sisa et al. (2016) found that spot spraying higher concentrations on the egg clutches with metaldehyde (5\%) and niclosamide (81.4\%) could have significant impacts on hatchability of eggs and could provide a more confined treatment, reducing the amount of molluscicides used and thus making it more economically feasible to use for resource-poor farmers.

In China, over 2000 chemicals have been developed and used since the 1950s for snail control but among these synthetic molluscicides, only niclosamide is recommended by the WHO. Therefore, a $50 \%$ wettable powder of niclosamide ethanolamine salt (WPN) is the only synthetic compound available in China, where it has been widely used in snail control in areas endemic for schistosomiasis (Xia et al., 2014). A novel molluscicide, quinoid-2', 5-dichloro-4'nitrosalicylanilide salt, has been developed that has the same molluscicide effects as WPN but is cheaper and is significantly less toxic to fish while another, a niclosamide suspension concentrate, was found to be physically more stable, more effective, and less toxic than WPN (Dai et al., 2008).

Hanifah et al. (2018) report on molluscicides registered in Brunei Darussalam, with niclosamide ethanolamine (traded by Bayer Company, Malaysia as Bayluscide) recommended for use in rice fields, but it is likely some rice farmers would have also used other available and more hazardous chemicals like metaldehyde in their paddy fields. Molluscicide formulations are sold under a government incentive programme and are applied twice per season, during the first month after transplanting, when young rice seedlings are particularly vulnerable to attack.

Dela Cruz et al. (2003) reported a basal application of complete fertilizer in combination with urea at the recommended rate incorporated into the soil could reduce snail populations by $54 \%$, thus preventing damage to the crop immediately after planting. However, while higher fertilizer concentrations have been found to increase snail mortality, they have also been highlighted to cause phytotoxicity, to impact on beneficials and to lead to eutrophication which in turn increases snail recruitment (Stuart et al., 2014). 
Chemicals used for the control of invasive apple snails are mostly persistent, dose-cumulative organotins which can have negative consequences for many organisms in the natural environment, including people, with reports of health effects such as loss of nails, skin problems, blurred vision and blindness (Mochida, 1991).

\subsection{Microbial pesticides}

Little is known of microorganisms associated with ampullariids that might be useful in control. In the Philippines, 12 bacterial isolates were tested, seven of which were effective against $P$. canaliculata (Cowie, 2002). Treatment of $P$. canaliculata eggs with the parasitic fungus Paecilomyces lilacinus led to $100 \%$ mortality of 1-day-old juvenile snails, susceptible to the conidia and only $12 \%$ of eggs hatched in contrast to $100 \%$ in controls (Maketon et al., 2009). However, the fungal susceptibility of juvenile snails was found to decrease as they aged, limiting its use as a biological control agent (Schnorbach et al., 2006). Further research into microbial pesticides would be beneficial.

\subsection{Botanicals}

Due to the high cost, toxicity, environmental contamination, and possible development of snail resistance to chemical molluscicides, natural molluscicides are rapidly being developed and a range of plant extracts with molluscicide properties have been identified to replace toxic chemicals (Joshi et al., 2005; Horgan, 2017). Many plant species have been assessed for molluscicidal activity, and some plants have been found to have potential value, such as Yucca desmetiana, Nerium indicum, Eucalyptus globulus, Jatropha gossypifolia and Saraca asoca (Yang et al., 2017). Several plants have active ingredients that may hold potential as biodegradable molluscicides, including saponins, flavonoids, steroids, tannins and other secondary metabolites (Valverde et al., 2010).

Among these, tea tree meal (from Camellia sasanqua seeds), a by-product of tea tree oil extraction has gained popularity in some countries and is noted to give up to $95 \%$ mortality (Yang et al., 2006). Other plant extracts developed for control which have variable efficiency depending on water conditions include quinoa (Chenopodium quinoa), Solanum spp. and Eucalyptus spp. (San Martin et al., 2008; Horgan, 2017), though registration has proved difficult for agricultural use because their safety has not been evaluated and some have lethal effects on beneficial aquatic organisms.

In Indonesia, the search for more eco-based cultural control techniques as alternatives to molluscicides has included the use of locally available and cost-effective plant-based traps (Syamsul et al., 2016). Results showed jackfruit skin and damaged pomelo were relatively more effective than tapioca leaves, water spinach leaves and old newspaper. Snails also displayed preference for fresh materials as compared to rotten materials. Demetillo et al. (2015) suggested Cymbopogon citratus (lemongrass) could be a potentially non-harmful organic substitute to synthetic molluscicide since crude extracts could alter the normal growth of $P$. canaliculata, preventing embryonic development, altering the incubation or hatching period of the egg and increasing mortality rates on both adult and juvenile stages. Antifeedant activity of essential oil from C. citratus and betel (Piper betle) were also suggested by Latip et al. (2017) for controlling GAS.

A pesticide formulated as an extract from the neem plant (Azadirachta indica) was also trialled in Malaysia in the laboratory with some effectiveness but has yet to be evaluated in the field (Latip et al., 2013). Huang et al. (2003) found powder extracts of soap nut pericarp from 
Sapindus mukorossi (Sapindaceae) attained 62\% mortality to GAS in paddy fields while bioassay experiments with a new acetylated triterpene saponin, hederagenin, also revealed molluscicidal effects against $P$. canaliculata. However, it was concluded that farmers tended to prefer the use of conventional pesticides as none of the botanical molluscicides identified had been produced commercially (Joshi, 2007).

Among the many molluscicidal compounds investigated, saponins are considered to be the most important group owing to their high molluscicidal activity (Yang et al., 2017).

\subsection{Resistant varieties}

In South-east Asia, rice plants were also found to be more resistant once they exceeded a certain age, 20-40 days depending on variety and a study conducted by Dela Cruz et al. (2002) reportedly found least-preferred varieties to be PSB Rc36, PSB Rc38, PSB Rc40 and PSB Rc68.

In Africa, agronomic development has enabled new varieties of rice, named 'New Rice for Africa' (NERICA) to be investigated; crosses between O. glaberrima and O. sativa combine the hardiness of the African species with the productivity of the Asian species (Linares, 2002) and can also shade out weeds, resist pests and droughts, grow in poor soils, and mature 3050 days earlier than traditional varieties, increasing productivity. This means that yields can be increased without major inputs and this could help offset losses to apple snails.

While there are no varieties resistant to the feeding of apple snails, modern high-tillering plant types can hold better potential to compensate for damaged tillers over time than low- and medium-tillering types. This may be helpful in long-duration (late-maturing) varieties, but may not help in short-duration (early-maturing) ones (Ranamukhaarachchi and Wickramasinghe, 2006). Use of high-tillering rice varieties such as PSB Rc36, PSB Rc38, PSB Rc40 and PSB Rc68 has been suggested (PhilRice, 2001; Dela Cruz et al., 2002).

Flooding fields with seawater has been used as a strategy to curb the presence of the invasive apple snail, taking advantage of the fact that it does not tolerate high salinity levels. Unfortunately, the residual salinity following the treatment with seawater generates losses in the crops which, in the worst cases, can affect up to $30 \%$ of production. As salt stress is one of the main environmental factors affecting rice growth and rice yield worldwide, major efforts have been made to increase the salt tolerance of rice through conventional and molecular breeding worldwide, but the extent of increase in salt tolerance has been limited, especially under field conditions (Hoang et al., 2016). In Spain, an EU-funded effort (NEURICE, 2016) has been focused on developing strategies for rice productivity, stability and quality by breeding hybrid varieties that carry the salt-resistant gene. These new varieties of rice may allow the sector to have new tools to combat the salinization of fields arising from rising sea levels due to climate change and to combat the apple snail (Pomacea insularum) invasion (IRTA, 2020). Of these, six varieties have already begun the process of varietal registration to be legally marketed.

\subsection{Biological control}

The versatility of a biological control approach for use in paddy fields as well as canals and ponds (Yusa and Wada, 1999) could be advantageous for snail control but none of the predators of apple snails in their native ranges have been shown to have a significant impact on their populations. Pomacea spp. have complex immunological defences, which include 
molecular and cellular components and as well as barrier organs which means they are not susceptible to infestation by many parasites.

Over the last decade or so, various $P$. canaliculata biocontrol candidates have been observed and investigated with variable results (Yusa et al., 2006; Guo and Zhang, 2015). The relatively small size of $P$. canaliculata hatchlings and their relatively thin shells allow them to be readily consumed (Hayes et al., 2012). An additional suite of predators target juvenile apple snails in their native range including crayfish (Procambarus sp.) and aquatic insects (water bugs, Belostoma sp.; dragonfly naiads, Coryphaeschna ingens; and diving beetles, Dytiscus marginalis) (Snyder and Snyder, 1971). However, in general, apple snails become decreasingly vulnerable to predation with size, and after reaching $20 \mathrm{~mm}$, relatively few predators in the non-native range in Asia can prey on them. The effectiveness of carp, tilapia, ducks and turtles has been evaluated in the field in the context of biological control (Cagauan and Joshi, 2002; Yusa, 2006; Yoshie and Yusa, 2008).

In some Asian, southern Latin American countries and in taro fields in Hawaii, the use of various duck varieties has proved a moderately effective, albeit expensive, strategy (Levin, 2006). Ducks are bred and herded into rice fields to eat young snails either prior to transplanting or when seedlings are 4 weeks old (5-10 ducks/ha), although results varied with race of duck and time of release (Teo, 2001; Brito and Joshi, 2016). Paddy-field dermatitis in farmers (Cagauan and Joshi, 2003) from the fluke-vectoring duck faeces has also deterred farmers from using this method.

The African catfish (Clarias gariepinus), Nile tilapia (Oreochromis niloticus) and common carp (Cyprinus carpio) have been released in paddy fields to predate snails (Halwart, 1994, 2006; Halwart et al., 1998; Ichinose et al., 2002) and as the more adaptable species in farmed environments, the common carp has been recommended for use in rice cultures at a density of ten fish per plot or 2041 fish/ha (Teo, 2006). Halwart et al. (2014) found common carp could suppress snail populations (including larger snails) by $58-87 \%$ compared to $48-87 \%$ by Nile tilapia, however, these proved ineffective against infestations by snails of a larger size as they ingest the whole shell. In Japan, black or Chinese carp (Mylopharyngodon piceus) and C. carpio fingerlings have been released to feed on newly hatched snails (Mochida, 1991). The practice of raising Chinese soft-shelled turtles (Pelodiscus sinensis) has also been adopted for use in wild rice fields (Zizania latifolia) in China and were a means of increasing revenue. However, the practical limitations of using fish, which need water deeper than normal rice fields, and ducks which inherently need care, infrastructure and rearing experience and maintenance preclude widespread use as biocontrol agents and are often incompatible with modern agricultural practices (Yoshie and Yusa, 2008). Furthermore, the use of molluscivorous fish for biocontrol should focus not only on potential effectiveness but also on the undesirable consequences of these introductions on non-target plants and animals (Ip et al., 2014).

Research by Savaya-Alkalay et al. (2018) found that the development of all-male prawn populations of Macrobrachium rosenbergii had the potential as a biocontrol agent over hatchlings and adults of Pomacea, with medium to large prawns preying on snails up to 15 $\mathrm{mm}$ in size, and small prawns effectively consuming snail hatchlings. Salcedo (2013) evaluated the pathogenicity of the nematode Heterorhabditis bacteriophora and showed that the inoculation of up to 16,000 nematodes per snail leads to $100 \%$ snail mortality in $96 \mathrm{~h}$.

In the Asian-introduced range, unintentionally introduced ant species such as fire ant (Solenopsis geminata) and Pheidologeton spp. were found to eat eggs (and newly hatched 
snails) in the field despite their toxicity (Yusa, 2001, 2006), but their impact has not been evaluated. Predators like leeches (Ozawa et al., 1989), firefly larvae (Kondo and Tanaka, 1989) or dragonfly larvae (Suzuki et al., 1999) have been found to consume snails in laboratory conditions but few predators are reported in the field (Yusa et al., 2000). Both rats and snakes have also been observed to prey on invasive apple snails ( $\mathrm{Ngoc}, 2002$; Dela Cruz et al., 2003).

Apple snails have evolved a number of remarkable life strategies to evade predation: as adults, they are moderately amphibious, their tubular siphon allowing them to breathe air while underwater, making them less vulnerable to snail-eating birds and their shell 'door' enabling them to close themselves off to predators and survive in the mud in periods of drought. By depositing their eggs above the waterline, cemented in a calcareous clutch, these snails can also defend their progeny against fish and other water inhabitants. Calcium-binding protein allows Pomacea to form a hard eggshell that physically protects the egg and prevents them from drying out. Apple snails avoid predators by crawling out of the water, situating themselves near the water surface, burying themselves in the mud, and falling from substrates on which they were crawling (Snyder and Snyder, 1971; Ichinose, 2002; Carlsson et al., 2004a; Aizaki and Yusa, 2009, 2010). In P. canaliculata, this behaviour is size dependent: hatchlings tend to crawl out of the water; juveniles mainly bury themselves or use near-surface habitats; larger snails are less responsive (Ichinose, 2002). While these behavioural responses are largely evolutionary, there have also been learned adaptations when exposed to novel predators (Aizaki and Yusa, 2010) and they may also be predator specific (Ueshima and Yusa, 2015).

Irrespective of their bright colouring, the lack of predators in their native South American range could also be attributed to their unpalatability. Dreon et al. (2014) found that the eggs are filled with a neurotoxic perivitellin called PV2 which helps defend against terrestrial predators. These life strategies, together with the relative absence of natural predators in the invaded range, have allowed $P$. canaliculata populations to rapidly establish and grow in new habitats (Brito and Joshi, 2016). Snails can also drop to the bottom of the water body and bury themselves in the mud until they get into contact with a hard object like a stone (Chan, et al., 2009).

Halwart (1994) recommended that specific natural enemies for $P$. canaliculata, such as the predatory Sciomyzidae, should be sought in its native home in South America but ultimately no truly successful biocontrol options have been found for $P$. canaliculata to date and indeed their use may in turn have negative impacts on other aquatic animals and plants (Yoshie and Yusa, 2008; Wong et al., 2009). As such, stringent evaluation prior to introduction would be required.

\subsection{Good agricultural practice}

Specific agricultural practices have been found to go some way to mitigate impact, with some of the most effective methods relating to land preparation and crop establishment. Studies have concluded that the magnitude of crop damage by invasive Pomacea depends on the technique used to grow rice (Wada et al., 1999; Sanico et al., 2002; Teo, 2003; Wada, 2006, in Burlakova et al., 2009). Snail damage to rice seedlings is correlated with the depth of water on the field, and damage decreases as seedling age increases. Increasing seedling age before planting from 2 to 5 weeks resulted in significant reductions in snail damage (Sanico et al., 2002). Arfan et al. (2016) found cultivation of rice using 28-day-old plants and transplanting seedlings at $2 \mathrm{~cm}$ water level reduced the damage by Pomacea spp. and achieved 
comparable yield to controls. Planting healthy and vigorous seedlings is also important. Despite the advantages of transplanting older seedlings, however, under high snail densities, even older seedlings will succumb to heavy damage (Sanico et al., 2002) and this should be combined with other damage reduction methods.

Limited moisture conditions immobilize and prevent the snail from causing severe damage even at high densities. Dry direct seeding, which uses a minimal amount of water in the early stages of growth, can limit snail damage compared to other methods (Teo, 2003) and increased seeding rate can also compensate for snail damage. Wada et al. (1999) found that draining after sowing/transplanting greatly reduces snail damage, and 3 weeks of drainage can almost prevent all damage. Since snails can withstand long periods of desiccation, draining will not kill them but because standing water facilitates their movement and they are immobile at depths less than half of their shell height, periodic draining of fields to a depth of $1 \mathrm{~cm}$ can effectively prevent $P$. canaliculata from moving and feeding (Wada et al., 1999; Wada, 2004). Farmers with their own pumps can manage water levels better than those served by large irrigation systems. Constraints to draining as a management tool are that rice seedlings may become stressed under dry conditions and that drained fields may suffer from greater weed incidence and competition with delicate rice seedlings (Horgan, 2017).

Wang et al. (2012) found water spraying and in particular submersion of eggs could dramatically decrease the hatchling rates to maximal $5.8 \%$ and increase the hatchling duration up to 26.4 days with both time of initiation of water treatment and the frequency of spray proving critical.

Because of their conspicuous and generally accessible egg masses, hand-picking eggs (and matured adults when they are active in the morning and evening) can also prove effective as an early intervention method (Bernatis and Warren, 2014). Furthermore, by placing bamboo stakes around the fields to provide places for snails to lay eggs, this can facilitate collection/destruction of eggs (Jahn et al., 1997). Dark pink eggs have been freshly laid and adult snails may be located close to the base of the stake, while pale pink eggs are close to hatching (Levin, 2006).

Construction of small canals or trenches, $15-25 \mathrm{~cm}$ wide and $5 \mathrm{~cm}$ deep for instance, along the edges of rice plots after the final land preparation, facilitate drainage and act as attractants for snails making manual collection or killing easier (PhilRice, 2001). Such canals can be dug for a distance of 5-15 m depending upon the degree of infestation of snails. Salleh et al. (2012) suggest using attractants like rotten jackfruit skin, papaya, cassava leaves, tapioca leaf and spinach and trap crop cultivation is also suggested by Gilal et al. (2016). These hand-picking methods, baited or not, while simple and potentially effective to remove congregating snails, are, however, very labour intensive (Horgan, 2017).

The use of physical barriers is also recommended, such as wire mesh or woven bamboo screen at the water inlet and outlet of the paddy planting area to prevent ingress and exit of snails to and from rice fields. Again, these methods can prove very labour intensive, particularly in highly infested areas, as they require frequent monitoring and cleaning (depending on mesh size) and if left unattended, could cause flooding. Overall, agricultural options for apple snail control recommend a combination of hand-picking and/or paddy rotation with canal screening could provide effective and cheap control. Removal of snails by handpicking during the period from the final harvest of the preceding crop to the final harrowing for the succeeding crop reduces the snail threat for the next crop (Wada, 2004). Recognizing the 
dynamics of water flow surrounding the fields can also help determine likely sources of invasion.

In Spain, paddies have been flooded with seawater in an attempt to control snail invasions (Loctier and Hackwill, 2018) but associated damage to the rice crop makes this a controversial method.

In direct-seeded rice, crop rotation may help reduce attack (Wada, 2004). When the soil is drained for the dryland crop, snails will burrow until the conditions become suitable for them. Using highland crops that require good soil aeration can render snails inactive until they starve and die. An alternate crop planted in rice fields in Japan, for example, is soybean, however, there are no research results on the minimum time period which the snails can survive and crop rotation may not be practical in marshy areas and those with frequently high-water levels or stagnant water. The System of Rice Intensification (SRI) is gaining popularity in many ricegrowing regions of the world, including Kenya and is based on a principle of reduced water use and greater yields (Kaloi et al., 2020). Though the economic returns of SRI are reportedly higher than conventional flooding systems, the labour requirement of SRI are reportedly high during the initial stages of land preparation and weeding (Kaloi et al., 2020). Any systems used and/or promoted in the rice-growing schemes in Mwea and other areas in Kenya should be mindful of the recommendations for snail control and ensure compatibility.

\subsection{Integrated pest management (IPM)}

Farmers globally have found a suite of practices, used in combination and taking a holistic approach, help to minimize snail damage. The key to success appears to be heightened vigilance and fine-tuning control practices to the environment and conditions.

One of the most important actions when a pest, such as this one, is detected is outreach education: informing and training farmers to help them contribute to reducing the impact and finding appropriate channels and formats to relay information. Rodriguez et al. (2017) reviewed actions taken in Ecuador where control measures were largely unsuccessful and slow to be implemented following first reports of the pest in 2005. The need for coordinated strategies and affordable recommendations which can be implemented by small-scale farmers with limited capacity for economic response were highlighted. Achandi et al. (2018) highlighted the importance of extension and advisory services for delivery and dissemination of information and new agricultural technologies to resource-poor farmers. Furthermore, genderbased constraints among women producers and workers in rice-hub-related activities need to be addressed to enhance the impact extension services can have. For instance, increasing the number and the interactivity of demonstration plots to allow better observation and adoption, and creating centralized and easily accessible communal spaces where flexible training, extension services (farmer field schools) and farmer-to-farmer exchanges and cooperation in management can be organized.

\section{Summary and recommendations on control methods}

The official identification of $P$. canaliculata in Kenya (Buddie et al., 2021) brings into sharp focus the need for rapid containment and KEPHIS have proposed measures to do so which reflect mitigation and management options recommended around the world. These include: (i) training and awareness raising in all rice-growing regions; (ii) use of physical barriers where water enters and exits fields; (iii) hand-picking snails and eggs; (iv) community-based snail management; (v) fast track pesticide registration; (vi) change cropping systems and planting 
patterns (avoid ratooning); (vii) manage water levels; (viii) emergency pesticide application; (ix) use of biocontrol and natural repellents; and ( $x$ ) identify pathways for movement and incursions. Table 2 provides a synthesis of management and best practice recommendations for for a range of stakeholders.

Given the relatively localized presence of snails, rapid response and early eradication in the affected agricultural area should be prioritized and preparation and implementation of a coordinated snail containment or eradication plan is urgently needed. Delimiting surveys (considering local and regional spread through connected fields, canals, rivers) and a census of the degree of infestation should be undertaken. Training and information to raise awareness should be disseminated to farmers to alert them of the threat as well as the suite of management and preventative measures available to mitigate spread. Intensive monitoring, through ongoing censuses is also recommended to provide insights regarding not only the impact of initial implementation, but also highlight where/when rapid corrective action is necessary (e.g. delimitation of demarcated areas, buffer zones around the infested areas, the concerted, community-based destruction of the pest in this area, enhanced hygiene protocols for any agriculture and aquaculture machinery).

Many countries and other administrative regions have developed quarantine restrictions related to Pomacea spp. and these should be adopted, if not already, together with investments to support consistent inspection. Identifying invasion risk pathways and preventing the movement of snails, either accidental along water courses or human mediated via traded infested plant materials or contaminated equipment is essential.

Without coordinated and decisive action, the invasive apple snails will continue to spread across both irrigated and rainfed lowland rice areas incurring serious crop losses or resorting to chemical concoctions as registered molluscicides are not readily available in the agrovets. Aside from phytotoxic damage to the rice crop, use of pesticides in water will have negative impacts on non-target fauna and flora including human health and the environment. Thus, long-term control and containment is crucial to reduce ecological and economic losses.

With a large number of invasive pest species affecting crops across Kenya, the recommendation to establish a collective technical working group on invasive species in the country has been proposed which would aim to prioritize and spearhead management efforts of species threatening livelihoods and food security. This unit should provide much-needed support and coordination to tackle invasions such as apple snail. 
Table 2. Recommendations on management and best practice. ${ }^{\mathrm{a}}$

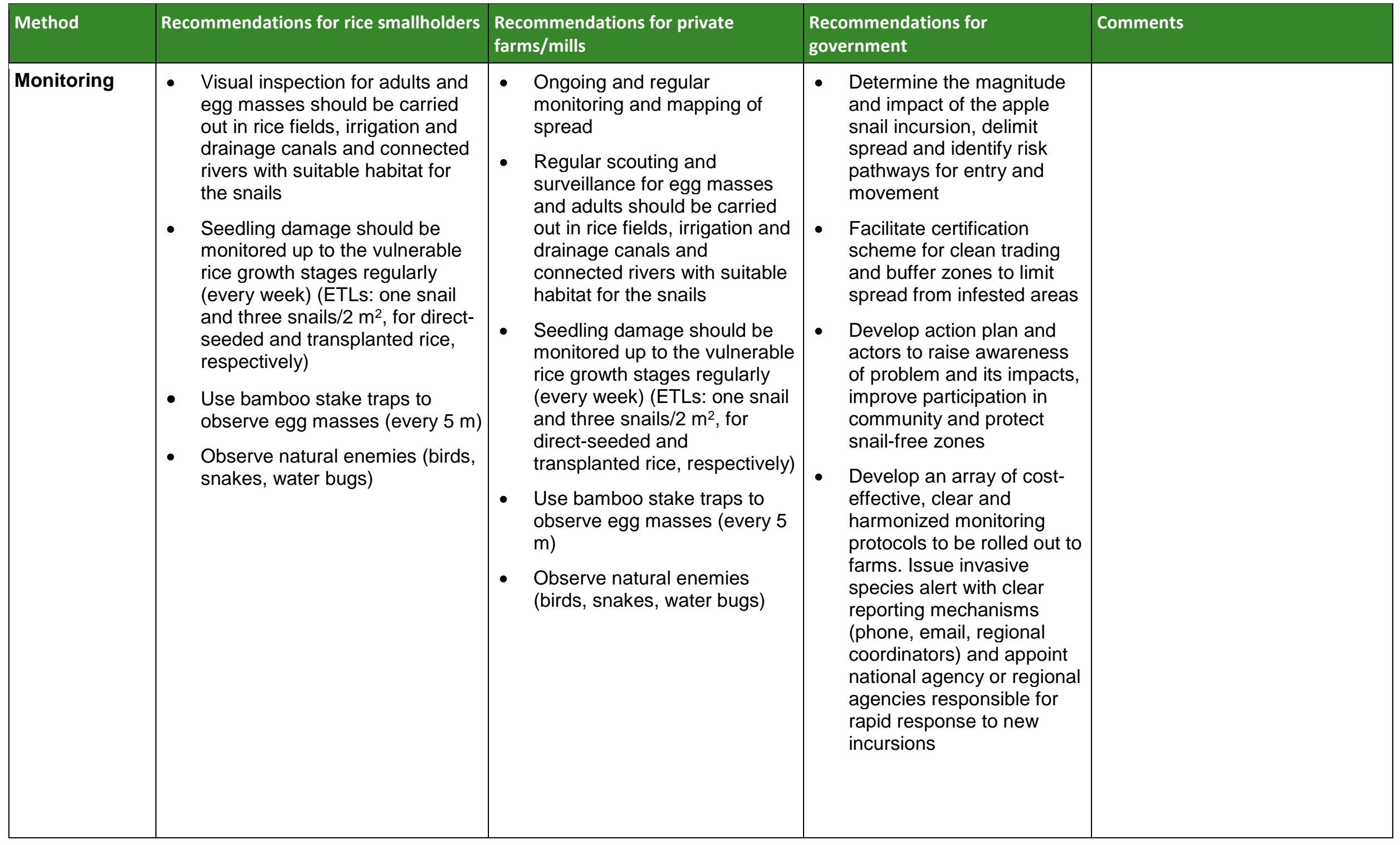




\begin{tabular}{|c|c|c|c|c|}
\hline Method & Recommendations for rice smallholders & $\begin{array}{l}\text { Recommendations for private } \\
\text { farms/mills }\end{array}$ & $\begin{array}{l}\text { Recommendations for } \\
\text { government }\end{array}$ & Comments \\
\hline
\end{tabular}




\begin{tabular}{|c|c|c|c|c|}
\hline Method & Recommendations for rice smallholders & $\begin{array}{l}\text { Recommendations for private } \\
\text { farms/mills }\end{array}$ & $\begin{array}{l}\text { Recommendations for } \\
\text { government }\end{array}$ & Comments \\
\hline
\end{tabular}




\begin{tabular}{|c|c|c|c|c|}
\hline Method & Recommendations for rice smallholders & $\begin{array}{l}\text { Recommendations for private } \\
\text { farms/mills }\end{array}$ & $\begin{array}{l}\text { Recommendations for } \\
\text { government }\end{array}$ & Comments \\
\hline
\end{tabular}




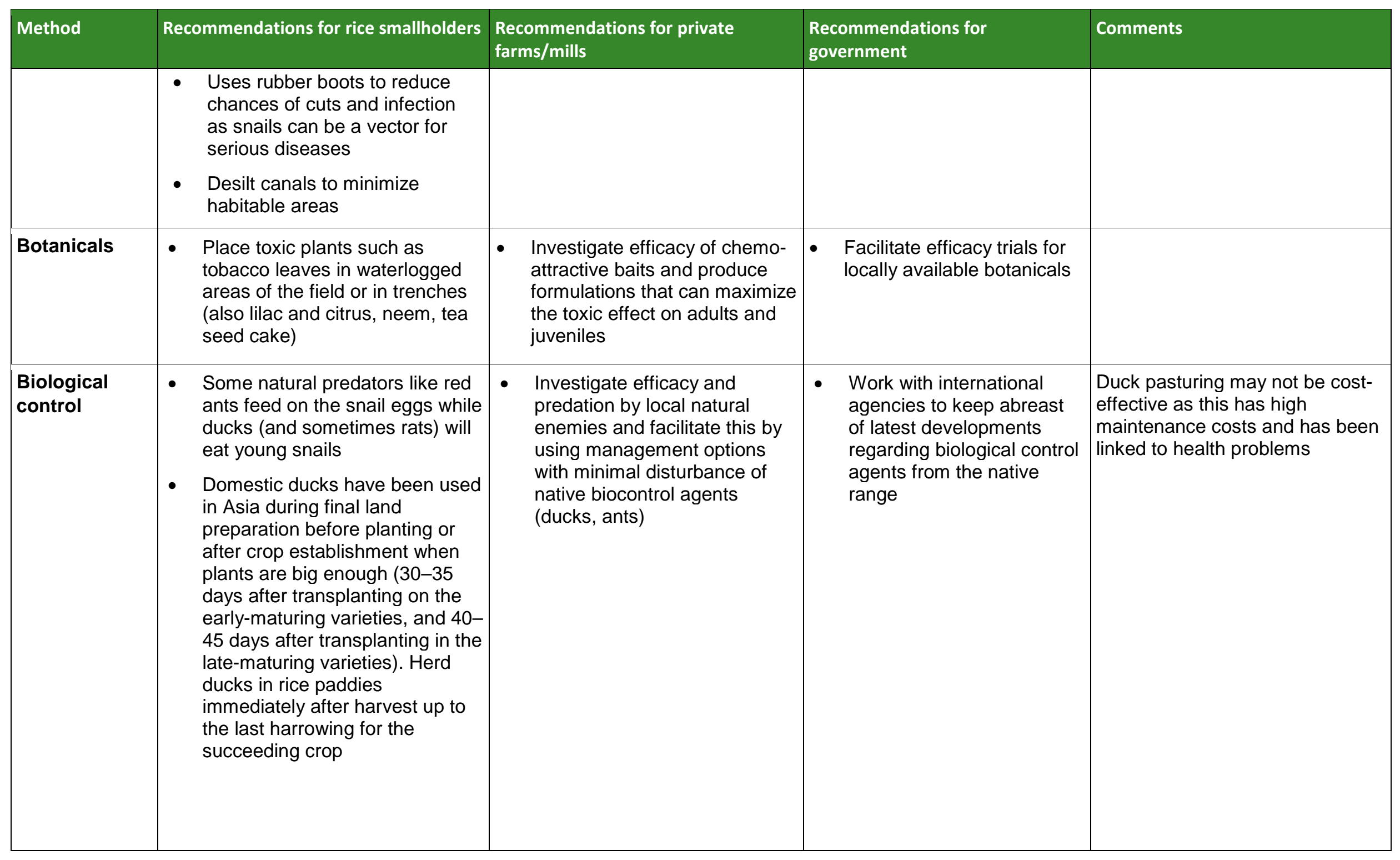




\begin{tabular}{|c|c|c|c|c|}
\hline Method & Recommendations for rice smallholders & $\begin{array}{l}\text { Recommendations for private } \\
\text { farms/mills }\end{array}$ & $\begin{array}{l}\text { Recommendations for } \\
\text { government }\end{array}$ & Comments \\
\hline $\begin{array}{l}\text { Resistant } \\
\text { varieties }\end{array}$ & $\begin{array}{l}\text { There are no varieties resistant } \\
\text { to apple snail feeding. Modern } \\
\text { high-tillering plant types have } \\
\text { better potential to compensate } \\
\text { for damaged tillers over time } \\
\text { than low- and medium-tillering } \\
\text { types and this may be helpful in } \\
\text { long-duration (late-maturing) } \\
\text { varieties, but may not help in } \\
\text { short-duration (early-maturing) } \\
\text { ones. Use rice varieties that } \\
\text { have rapid elongation after } \\
\text { seedling establishment }\end{array}$ & $\begin{array}{l}\text { - Investigate modern high- } \\
\text { tillering plant types to } \\
\text { compensate for damage } \\
\text { - Use rice varieties that have } \\
\text { rapid elongation after seedling } \\
\text { establishment }\end{array}$ & $\begin{array}{l}\text { - Facilitate research and } \\
\text { market availability of } \\
\text { modern rice varieties which } \\
\text { can compensate more } \\
\text { effectively for damage }\end{array}$ & \\
\hline
\end{tabular}




\begin{tabular}{|c|c|c|c|c|}
\hline Method & Recommendations for rice smallholders & $\begin{array}{l}\text { Recommendations for private } \\
\text { farms/mills }\end{array}$ & $\begin{array}{l}\text { Recommendations for } \\
\text { government }\end{array}$ & Comments \\
\hline Biopesticides & $\begin{array}{l}\text { Use registered biopesticide } \\
\text { products instead of pesticides if } \\
\text { available }\end{array}$ & $\begin{array}{l}\text { - Use registered microbial } \\
\text { biopesticides if recommended } \\
\text { by government } \\
\text { - Test locally available } \\
\text { biopesticides }\end{array}$ & $\begin{array}{ll}\text { - } & \text { Accept supporting data } \\
\text { from other countries for } \\
\text { registration of } \\
\text { biopesticides } \\
\text { - } & \text { Fast track registration for } \\
\text { products already } \\
\text { registered in America and } \\
\text { Asia for this pest }\end{array}$ & $\begin{array}{l}\text { Not commercially available in } \\
\text { Africa }\end{array}$ \\
\hline $\begin{array}{l}\text { Chemical } \\
\text { control }\end{array}$ & $\begin{array}{l}\text { - Use pesticides as a last resort, } \\
\text { and only when economic } \\
\text { thresholds are reached } \\
\text { - When all the non-chemical } \\
\text { options failed, farmers could } \\
\text { apply approved molluscicide } \\
\text { - Application should be done } \\
\text { early in the morning or late in } \\
\text { the afternoon when the snails } \\
\text { are out and active } \\
\text { Use only pesticides } \\
\text { (molluscicides) recommended } \\
\text { by the government for rice } \\
\text { Follow all advice on safety, } \\
\text { dilution, etc. on the product } \\
\text { label } \\
\text { Buy only from registered } \\
\text { pesticide dealers } \\
\text { Use proper PPE when applying } \\
\text { pesticides, and observe the } \\
\text { DOA and RD recommendation } \\
\text { for dosage and method }\end{array}$ & $\begin{array}{l}\text { - Use pesticides as a last } \\
\text { resort, and only when } \\
\text { economic thresholds are } \\
\text { reached } \\
\text { - Spray regime should be } \\
\text { based on an action threshold } \\
\text { that takes into consideration } \\
\text { expected value of crop, } \\
\text { expected loss if untreated, } \\
\text { and cost of treatment } \\
\text { Do not spray as a } \\
\text { preventative measure } \\
\text { Use pesticides recommended } \\
\text { by the government, especially } \\
\text { those with lower } \\
\text { environmental impact } \\
\text { Use proper PPE when } \\
\text { applying pesticides, and } \\
\text { observe the re-entry intervals } \\
\text { and pre-harvest intervals of } \\
\text { the product } \\
\text { Apply products only to low } \\
\text { spots and canalettes rather } \\
\text { than to the whole field. }\end{array}$ & $\begin{array}{l}\text { - Facilitate efficacy trials } \\
\text { and fast-tracking for } \\
\text { registration of safe 'green' } \\
\text { products for use on the } \\
\text { pest through the PCPB in } \\
\text { collaboration with } \\
\text { agrochemical industries } \\
\text { and institutions } \\
\text { - } \text { Monitor the health and } \\
\text { environmental impacts of } \\
\text { pesticides. Niclosamide is } \\
\text { toxic to fish and amphibia } \\
\text { (frogs and toads) } \\
\text { Prepare a technical } \\
\text { guidance standard for } \\
\text { pesticides covering } \\
\text { procurement, risk } \\
\text { reduction and resistance } \\
\text { management } \\
\text { Monitor for pesticide } \\
\text { resistance to most popular } \\
\text { active ingredients }\end{array}$ & $\begin{array}{l}\text { Note that pesticides are highly } \\
\text { toxic to fish and other non-target } \\
\text { animals and have been linked to } \\
\text { human health hazards idely used }\end{array}$ \\
\hline
\end{tabular}




\begin{tabular}{|c|c|c|c|c|}
\hline Method & Recommendations for rice smallholders & $\begin{array}{l}\text { Recommendations for private } \\
\text { farms/mills }\end{array}$ & $\begin{array}{l}\text { Recommendations for } \\
\text { government }\end{array}$ & Comments \\
\hline & $\begin{array}{l}\text { - Apply products only to low } \\
\text { spots and canalettes rather } \\
\text { than to the whole field. Always } \\
\text { ensure safe application. Spray } \\
\text { in the morning and afternoon } \\
\text { when snails are active } \\
\text { - } \quad \text { If used as emergency measure } \\
\text { in high-risk areas, } \\
\text { molluscicides should only be } \\
\text { used immediately after } \\
\text { transplanting or during the } \\
\text { seedling establishment phase } \\
\text { in direct-seeded rice; and only } \\
\text { for rice younger than } 30 \text { days } \\
\text { old } \\
\text { Prior to the application of } \\
\text { molluscicide irrigate the field to } \\
\text { activate the snails and so they } \\
\text { emerge out of the soil. This is } \\
\text { important for the snails to get in } \\
\text { contact with the pesticide } \\
\text { Consider ETLs of snails for } \\
\text { direct action (one snail/2 m² } \\
\text { and three snails/2 m², for } \\
\text { direct-seeded and transplanted } \\
\text { rice, respectively) to prevent } \\
\text { risk of damage and yield loss } \\
\text { with rapidly increasing } \\
\text { population }\end{array}$ & $\begin{array}{l}\text { Always ensure safe } \\
\text { application. Spray in the } \\
\text { morning and afternoon when } \\
\text { snails are active } \\
\text { - If used as an emergency } \\
\text { measure in high-risk areas, } \\
\text { molluscicides should only be } \\
\text { used immediately after } \\
\text { transplanting or during the } \\
\text { seedling establishment phase } \\
\text { in direct-seeded rice; and only } \\
\text { for rice younger than } 30 \text { days } \\
\text { old } \\
\text { Prior to the application of } \\
\text { molluscicide irrigate the field } \\
\text { to activate the snails and so } \\
\text { they emerge out of the soil. } \\
\text { This is important for the } \\
\text { snails to get in contact with } \\
\text { the pesticide } \\
\text { Consider ETLs of snails for } \\
\text { direct action (one snail/2 m² } \\
\text { and three snails/2 m², for } \\
\text { direct-seeded and } \\
\text { transplanted rice, } \\
\text { respectively) to prevent risk of } \\
\text { damage and yield loss with } \\
\text { rapidly increasing population }\end{array}$ & $\begin{array}{l}\text { Publish and make public } \\
\text { the list of pesticides } \\
\text { registered }\end{array}$ & \\
\hline
\end{tabular}

a DOA, Department of Agriculture; ETL, economic threshold level; IPM, integrated pest management; PCPB, Pest Control Products Board; PPE, personal protective equipment; RD, recommended dose. 


\section{Advice, information and communication}

\subsection{Sources of information on apple snail control}

Smallholder rice farmers in Kenya rely on the government's National Irrigation Authority for information, occasioned by synchronization of activities. For Mwea, MIAD (Mwea Irrigation Agricultural Development) also plays a pivotal role when it comes to research and training in irrigated agriculture. Extension officers are drawn from the Ministry of Agriculture and NIB to provide information and some have had training through Plant Clinics. Agricultural trade fairs may also be a source of information. Farmers are also known to get information from agro-dealers and input-suppliers to manage pests and diseases, with mass media channels, agricultural pieces on radio and TV, the internet, newspapers and magazines also playing a role in disseminating information. As for other pests, neighbours, friends, family and lead farmers will also be a source of information. As invasive snails are a new pest, farmers may not be familiar with management options and identification and the multi-institutional technical team (MITT) will aim to develop technical materials to disseminate to raise awareness. The National Irrigation Authority will also aim to undertake training and demonstrations on the management of the pest to farmers and stakeholders, with the support of other county teams. A socio-economic survey could provide a valuable baseline on the information farmers have had and the management methods currently adopted to tackle the snail where it has invaded, as well as establishing the level of knowledge in areas which remain free of snails but could be at risk.

\subsection{Criteria for control advice}

The criteria for control advice presented in this section are adapted from Abrahams et al. (2017) and are relevant for any method for managing an invasive pest.

We recommend the following criteria for control advice:

Efficacy. This is often assumed to be the most important criterion, even if this is not stated explicitly. If a practice is to be recommended there should be some evidence that it will be effective in at least some situations. Where a product has to be registered, this generally includes demonstration of efficacy, but many IPM practices do not involve a registered product. Results from controlled trials in an appropriate context are desirable, though not always available.

Safety. Even registered products can be hazardous to human health without precautions. Safety should thus be considered based on a consideration of how the product is likely to be used rather than whether recommended safety precautions are adequate. Some practices not requiring registration can also be hazardous, such as some plant extracts.

Sustainability. Possible effects on non-target organisms, such as native molluscs, natural enemies and other organisms, should be considered. A control method may also have potential to create new problems, such as resurgence of other pests or pesticide resistance.

Practicality. Some methods may be impractical for some farmers, particularly those requiring elaborate safety precautions. Others may be only practical at a small scale.

Availability. Availability of regulated products is initially determined by their registration status, but even registered products may not be widely stocked if distribution is expensive and/or the perceived market is small. 
Cost-effectiveness. At the simplest level the cost of control must be less than the value of crop loss avoided, for it to be worthwhile. Opportunity and other costs may need to be considered.

In practice, many of these criteria are context specific, so recommendations and advice are unlikely to suit all farmers in all situations. This highlights different underlying approaches to the role of advisory services. The linear 'transfer of technology' approach emphasizes prescriptive advice on the use of new technologies. Participatory approaches emphasize educating and empowering farmers to use information and experience to make their own choices. Both approaches have advantages and disadvantages.

\subsection{Information resources and tools}

A large number of international resources are available for $P$. canaliculata:

Global Invasive Species Database - Pomacea canaliculata (mollusc).

http://www. iucngisd.org/gisd/species.php?sc=135

PaDIL - Golden Apple Snail Australian Plant Biosecurity Cooperative Research Centre. Pests and

Diseases Image Library. https://www.padil.gov.au/pests-and-diseases/pest/main/136489

Plantwise Technical Factsheet - Golden Apple Snail (Pomacea canaliculata). CABI. Plantwise

Knowledge Bank. https://www.plantwise.org/knowledgebank/datasheet/68490

Pest survey card on Pomacea spp. from EFSA.

https://efsa.onlinelibrary.wiley.com/doi/pdfdirect/10.2903/sp.efsa.2020.EN-1877

Invasive Species Compendium: This is a free encyclopaedic resource that brings together a wide range of different types of science-based information to support decision making in invasive species management worldwide. www.cabi.org/isc

Crop Protection Compendium: This is an encyclopaedic resource that brings together a wide range of different types of science-based information on all aspects of crop protection. It comprises detailed datasheets on pests, diseases, weeds, host crops and natural enemies. https://www.cabi.org/cpc

For Africa:

KEPHIS has outlined plans to work with stakeholders in the management Pomacea snails. The stakeholders include the Kirinyaga County government, Ministry of Agriculture, National Irrigation Authority, PCPB, KALRO, MIAD, NGAO, WARMA, NEMA, Department of Public Health, the Presidential Delivery Unit, CABI, ICIPE and the University of Nairobi. This forms a MITT.

Rice Knowledge Bank: Golden Apple Snail. International Rice Research Institute. http://www.knowledgebank.irri.org/step-by-step-production/growth/pests-and-diseases/golden-applesnails 


\section{Recommendations}

Invasive apple snails remain a problem across their introduced range because of their inherent biological and ecological characteristics and their adaptability to harsh environments. Prevention is the best form of management and strict quarantine must be enforced to prevent further spread across the continent. For countries which are free of snails, identifying potential introduction pathways, developing risk assessments, implementing a clean certification scheme for traded plants from contaminated areas and elaborating rapid response plans for new incursions will be important to help mitigate impact. Once detected, containment is crucial and while eradication is not impossible, it will rely on a swift, coordinated high-level strategy to highlight the threat among smallholders and commercial growers and to engage the community to contain and mitigate the pest. Continuous vigilance and integrated management approaches including hand-picking of adults, destruction of egg masses, baiting and trapping, barriers and the adoption of mitigating agricultural practices, such as crop rotation and water management, will need to be carried out to try to keep the snails below an economic threshold. Regular monitoring and delimiting surveys are also essential.

Awareness-raising programmes should also aim to relay the importance of sustainable management in $P$. canaliculata control to conserve the environment and native invertebrates, with special emphasis on molluscs as important engineers in rice ecosystems. It is essential to identify the most effective and rapid pathways for dissemination of knowledge on $P$. canaliculata, its impacts and management so that it reaches as many farmers as possible and includes regions where it has not yet arrived.

\section{High-level policy makers:}

- Determine the magnitude of the invasive apple snail threat (present and potential) and make policy decisions, backed by available economic estimates and science-based evidence.

- Lobby for budgetary allocation to facilitate an immediate, official national response backed by policy and legislation to enable coordinated (potentially mandatory) contingency action to contain and eliminate the invasive apple snail at the earliest opportunity.

- Outline clear structure and division of responsibility between competent authorities for the development, implementiaton and support of eradication/containment measures in Kenya.

- Provide countrywide support for invasive apple snail control and farmer/agency education and outreach by establishing a technical working group to spearhead management efforts.

- Make informed, science-based decisions at national level to protect biodiversity, consumers and trade from indiscriminate molluscicide/pesticide use.

\section{Regulators:}

- Identify pathways for entry and spread of the snail to vulnerable areas and contain/quarantine affected areas.

- Ensure awareness is raised to prevent further deliberate and accidental distribution of $P$. canaliculata.

- Organize regular and persistent monitoring schemes for snail egg masses and adults to inform rapid response and containment measures. 
- Fast-track registration and efficacy trials for safe pesticides to use on the pest (PCPB in collaboration with agrochemical industries and efficacy trials institutions).

- Facilitate and promote fast-track registration of lower-risk 'green' products for snail management including biopesticides, botanicals and the potential use of native natural enemies.

\section{Researchers:}

- Carry out countrywide distribution, socio-economic and impact surveys to assess the extent and awareness of the problem.

- Investigate efficacy of native biocontrol agents and test locally available and legally approved biopesticides and botanicals and produce formulations that maximize the toxic effect on $P$. canaliculata and reduce side effects on beneficial fauna.

- No rice varieties are resistant to apple snails, but research into modern high-tillering plant types can hold better potential to compensate for damage - investigate tolerant rice varieties.

\section{Advisory services:}

- Communicate to farmers, using accessible and varied platforms, the negative impacts of indiscriminate pesticide use on their health and the environment.

- Consider efficacy, safety, sustainability, practicality, availability and cost-effectiveness when recommending control practices.

- Raise awareness of the snail problem (through media and pest alert flyers) and expand extension efforts to facilitate community-based management, coordinating immediate action if the invasive snail is detected.

- Promote good agricultural practice and low-risk, cost-effective options for management such as changes to planting patterns, water management, hand-picking, physical barriers and repellent plants.

- Develop an array of cost-effective, clear and harmonized monitoring protocols to be rolled out to smallholders.

\section{Private farms:}

- Follow good agricultural practice advice relating to alternative cropping systems and planting patterns (avoiding ratooning postharvest), including managing water levels, desilting and crop establishment age.

- Maintain good records of agronomy, monitoring, interventions, yield, etc., and review regularly to determine the cost-benefit of the control methods used.

- Spraying of registered and crop-approved molluscicide should be based on an action threshold that takes into consideration the expected value of the crop, the expected loss if untreated, and the cost of treatment. 
- Farm workers should use the proper PPE when applying pesticides and use the suite of recommended agricultural and cultural practices to manage snail populations.

- Assess the efficacy of other lower-risk products, if available, and adopt for use.

\section{Smallholder farmers:}

- Use only pesticides recommended by the government for this pest and choose low-risk botanical options if available/affordable.

- Engage with community extension, advisory and information services to obtain latest information on snail identification and management.

- Engage in regular surveillance and monitoring for egg masses and adult snails on farms (use bamboo poles/attractants, locally available materials).

- Use a suite of management practices, in combination to minimize damage (scouting, handpicking, trapping, baiting, trenches, physical barriers, etc.) as part of routine, community management action.

- Follow good agricultural practice advice relating to hygiene protocols for equipment and machinery, alternative cropping systems and planting patterns (avoiding ratooning postharvest), including managing water levels, desilting and crop establishment age (transplanted rice is less vulnerable than direct-seeded rice).

\section{Acknowledgements}

This paper was prepared as part of the Action on Invasives and Plantwise Plus programmes. Action on Invasives is supported by the UK Foreign, Commonwealth and Development Office (FCDO) and the Netherlands Directorate General for International Cooperation (DGIS). Plantwise Plus, in addition to FCDO and DGIS, is also funded by European Commission Directorate-General for International Cooperation and Development (DEVCO) and Swiss Agency for Development and Cooperation (SDC). We thank the survey respondents, including those whose partial responses have been quoted with their permission.

$\mathrm{CABI}$ is an international intergovernmental organization, and we gratefully acknowledge the core financial support from our member countries (and lead agencies) including the UK (FCDO), China (Chinese Ministry of Agriculture and Rural Affairs), Australia (Australian Centre for International Agricultural Research), Canada (Agriculture and Agri-Food Canada), the Netherlands (DGIS) and Switzerland (Swiss Agency for Development and Cooperation). See http://www.cabi.org/aboutcabi/who-we-work-with/key-donors/ for full details.

The authors would like to acknowledge the contributions of Dr Ravindra C. Joshi, Senior Consultant, Philippine Rice Research Institute (PhilRice), Department of Agriculture, Philippines and Associate, CABI-SEA, Malaysia for reviewing the paper and sharing his expertise on invasive apple snails. 


\section{References}

Abdullahi, M., Mizutani, M., Tanaka, S., Goto, A. and Matsui, H. (2003) Changes in water management practices in the Mwea Irrigation Scheme, Kenya from 1994 to 1998. Rural and Environment Engineering 44, 60-67. https://doi.org/10.11408/jierp1996.2003.44 60

Abrahams, P., Bateman, M., Beale, T., Clottey, V., Cock, M., et al. (2017) Fall Armyworm: Impacts and Implications for Africa; Evidence Note (2). CAB International, Wallingford, UK, 142 pp.

Achandi, E.L., Mujawamariya, G., Agboh-Noameshie, A.R., Gebremariam, S., Rahalivavololona, N. and Rodenburg, J. (2018) Women's access to agricultural technologies in rice production and processing hubs: a comparative analysis of Ethiopia, Madagascar and Tanzania. Journal of Rural Studies 60, 188-198. https://doi.org/10.1016/j.jrurstud.2018.03.011

Acosta, B.O. and Pullin, R.S.V. (1991) Environmental Impact of the Golden Snail (Pomacea sp.) on Rice Farming Systems in the Philippines. Freshwater Aquaculture Center, Central Luzon State University, Nueva Ecija; ICLARM, Manila, 34 pp.

Adalla, C.B. and Rejesus, B.M. (1989) The golden apple snail, Pomacea sp., a serious pest of lowland rice in the Philippines. In: Henderson, I.F. (ed.) Slugs and Snails in World Agriculture.

Proceedings of a symposium organized by the British Crop Protection Council, Surrey. British Crop Protection Monograph 41, 417-422.

Adalla, C.B. and Magsino, E.A. (2006) Understanding the golden apple snail (Pomacea canaliculata): biology and early initiatives to control the pest in the Philippines. In: Joshi, R.C. and Sebastian, L.S. (eds) Global Advances in Ecology and Management of Golden Apple Snails. Philippine Rice Research Institute, Nueva Ecija, Philippines, pp. 199-213.

Aditya, G. and Raut, S.K. (2001) Food of the snail, Pomacea bridgesi, introduced in India. Current Science 80(8), 919-921.

Aizaki, K. and Yusa, Y. (2009) Field observations of the alarm response to crushed conspecifics in the freshwater snail Pomacea canaliculata: effects of habitat, vegetation, and body size. Journal of Ethology 27, 175-180. https://doi.org/10.1007/s10164-008-0103-2

Aizaki, K. and Yusa, Y. (2010) Learned predator response in a freshwater snail, Pomacea canaliculata. Malacologia 52(1), 21-29. https://doi.org/10.4002/040.052.0102

Al-Abbad, M.Y., Hamzah, H.A. and Khalaf, R.Z. (2015) First record of the invasive apple snail Pomacea canaliculata (Lamarck, 1822) (Gastropoda: Ampullariidae) in Shatt Al-Arab River, Southern Iraq with some ecological aspects. Marsh Bulletin 10(2), 92-101. Available at: https://search.emarefa.net/en/detail/BIM-962582-first-record-of-the-invasive-apple-snailpomacea-canaliculat (accessed 14 February 2021).

Albrecht, E.A., Carreño, N.B. and Castro-Vazquez, A. (1996) A quantitative study of copulation and spawning in the South American apple snail, Pomacea canaliculata (Prosobranchia: Ampullariidae). Veliger 39(2), 142-147.

Albrecht, E.A., Carreño, N.B. and Castro-Vazquez, A. (1999) A quantitative study of environmental factors influencing the seasonal onset of reproductive behaviour in the South American apple snail Pomacea canaliculata (Gastropoda: Ampullariidae). Journal of Molluscan Studies 65(2), 241-250. https://doi.org/10.1093/mollus/65.2.241

Anderson, B. (1993) The Philippine snail disaster. The Ecologist 23, 70-72.

Andree, K.B. and López, M.A. (2013) Species identification from archived snail shells via genetic analysis: a method for DNA extraction from empty shells. Molluscan Research 3, 1-5.

Andrews, P., Thyssen, J. and Lorke, D. (1983) The biology and toxicology of molluscicides, Bayluscide. Pharmacology \& Therapeutics 19, 245-295. 
Ang, W. (1984) Snails in the human diet. Greenfields 14, 30-31.

Arfan, A., Muhamad, R., Omar, D., Azwady, A. and Manjeri, G. (2014) Distribution of two Pomacea spp. in rice fields of Peninsular Malaysia. Annual Research \& Review in Biology 4, 4123-4136. https://doi.org/10.9734/ARRB/2014/11398

Arfan, A.G., Muhamad, R., Omar, D., Azwady, A.A.N. and Manjeri, G. (2016) Population fluctuation and dispersion patterns of apple snails, Pomacea spp. (Gastropoda: Ampullariidae) in a rice ecosystem. Pertanika Journal of Tropical Agricultural Science 39(3), 343-357.

Arouna, A., Lokossou, J.C., Wopereis, M.C.S., Bruce-Oliver, S. and Roy-Macauley, H. (2017) Contribution of improved rice varieties to poverty reduction and food security in sub-Saharan Africa. Global Food Security 14, 54-60. https://doi.org/10.1016/i.gfs.2017.03.001

Atera, E.A., Onyancha, F.N. and Majiwa, E. (2018) Production and marketing of rice in Kenya: challenges and opportunities. Journal of Development and Agricultural Economics 10, 64-70. https://doi.org/10.5897/JDAE2017.0881

Baker, G.H. (1998) The golden apple snail, Pomacea canaliculata (Lamarck) (Mollusca: Ampullariidae), a potential invader of fresh water habitats in Australia. In: Zalucki, M.P., Drew, R.A.I. and White, G.G. (eds) Proceedings of the Sixth Australasian Applied Entomological Research Conference, Volume 2. University of Queensland, Brisbane, Australia, pp. 21-26.

Balasubramanian, V., Sie, M., Hijmans, R.J. and Otsuka, K. (2007) Increasing rice production in subSaharan Africa: challenges and opportunities. Advances in Agronomy 94, 55-133. https://doi.org/10.1016/S0065-2113(06)94002-4

Baloch, W.A. (2017) Country report (Pakistan) on non-native apple snails. In: Joshi, R.C., Cowie, R.H. and Sebastian, L.S. (eds) Biology and Management of Invasive Apple Snails. Philippine Rice Research Institute, Nueva Ecija, Philippines, pp. 213-219.

Baloch, W.A., Memon, U.N., Burdi, G.H., Soomro, A.N., Tunio, G.R. and Khatian, A.A. (2012) Invasion of channeled apple snail Pomacea canaliculata, Lamarck (Gastropoda: Ampullariidae) in Haleji Lake, Pakistan. Sindh University Research Journal (Science Series) 44, 263-266.

Barbitta, D., Clavijo, C. and Carranza, A. (2020) Ecoregional-level assessment of the potential distribution of the invasive apple snail Pomacea maculata Perry, 1810 (Gastropoda: Ampullariidae): setting geographically explicit priorities for the management of the invasion. Russian Journal of Biological Invasions 11, 172-181. https://doi.org/10.1134/S2075111720020022

Becker, M. and Johnson, D.E. (2001) Improved water control and crop management effects on lowland rice productivity in West Africa. Nutrient Cycling in Agroecosystems 59, 119-127. https://doi.org/10.1023/A:1017585328904

Benson, A.J. (2018) Non-indigenous aquatic species: Pomacea maculata. USGS Nonindigenous Aquatic Species Database, Gainesville, Florida. Available at: https://nas.er.usgs.gov/queries/FactSheet.aspx?speciesID=2633 (accessed 11 May 2020).

Bernatis, J.L. and Warren, G.L. (2014) Effectiveness of a hand removal program for management of nonindigenous apple snails in an urban pond. Southeastern Naturalist 13, 607-618. https://doi.org/10.1656/058.013.0320

Berry, J.P. and Lind, O. (2010) First evidence of 'paralytic shellfish toxins' and cylindrospermopsin in a Mexican freshwater system, Lago Catemaco, and apparent bioaccumulation of the toxins in 'tegogolo' snails (Pomacea patula catemacensis). Toxicon 55, 930-938.

https://doi.org/10.1016/j.toxicon.2009.07.035

Berthold, T. (1991) Vergleichende anatomie, phylogenie und historische biogeographie der Ampullariidae (Mollusca, Gastropoda). Abhandlungen des Naturwissenschaftlichen Vereins in Hamburg (NF) 29, 1-256. 
Bertolero, A. and Navarro, J. (2018) A native bird as a predator for the invasive apple snail, a novel rice field invader in Europe. Aquatic Conservation: Marine and Freshwater Ecosystems 28(5), 1099-1104. https://doi.org/10.1002/aqc.2917

Boss, K.J. and Parodiz, J.J. (1977) Paleospecies of neotropical Ampullariids and notes on other fossil non-marine South American gastropods. Annals of Carnegie Museum 46, 107-127.

Brandt, R.A. (1974) The non-marine aquatic Mollusca of Thailand. Archiv für Molluskenkunde 105, 1405.

Brito, F.C. de and Joshi, R.C. (2016) The golden apple snail Pomacea canaliculata: a review on invasion, dispersion and control. Outlooks on Pest Managment 27, 157-163. https://doi.org/10.1564/v27 aug 03

Brola, T.R., Dreon, M.S., Fernández, P.E., Portiansky, E.L. and Heras, H. (2021) Ingestion of poisonous eggs from the invasive apple snail Pomacea canaliculata adversely affects bullfrog Lithobathes catesbeianus intestine morphophysiology. Malacologia 63(2), 171-182. https://doi.org/10.4002/040.063.0202

Buddie, A.G., Rwomushana, I., Offord, L.C., Kibet, S., Makale, F., et al. (2021) First report of the invasive snail Pomacea canaliculata in Kenya. CABI Agriculture and Bioscience 2, 11. https://doi.org/10.1186/s43170-021-00032-z

Burkett-Cadena, N.D. and Unnasch, T.R. (2013) Apple snails and tiger mosquitoes: a curious association between two invasive species in Florida, USA. Paper presented at Entomology 2013, 61st Annual Meeting of the Entomological Society of America, 10-13 November 2013, Austin Convention Center, Austin, Texas. Available at:

https://esa.confex.com/esa/2013/webprogram/Session20756.html (accessed 4 March 2021).

Burks, R.L., Hensley, S.A. and Kyle, C.H. (2011) Quite the appetite: juvenile island apple snails (Pomacea insularum) survive consuming only exotic invasive plants. Journal of Molluscan Studies 77, 423-428. https://doi.org/10.1093/mollus/eyr022

Burlakova, L.E., Karatayev, A.Y., Padilla, D.K., Cartwright, L.D. and Hollas, D.N. (2009) Wetland restoration and invasive species: apple snail (Pomacea insularum) feeding on native and invasive aquatic plants. Restoration Ecology 17, 433-440. https://doi.org/10.1111/j.1526100X.2008.00429.X

Byers, J.E., McDowell, W.G., Dodd, S.R., Haynie, R.S., Pintor, L.M. and Wilde, S.B. (2013) Climate and $\mathrm{pH}$ predict the potential range of the invasive apple snail (Pomacea insularum) in the Southeastern United States. PLOS ONE 8: e56812. https://doi.org/10.1371/journal.pone.0056812

CABI (2020) Pomacea canaliculata. Invasive Species Compendium. CAB International, Wallingford, UK. Available at: https://www.cabi.org/isc/datasheet/68490 (accessed 15 April 2020).

Cagauan, A.G. and Joshi, R.C. (2002) Predation of freshwater fish on golden apple snail, Pomacea canaliculata Lam., under screenhouse conditions. International Rice Research Notes 27(2), 2426.

Cagauan, A.G. and Joshi, R.C. (2003) Golden apple snail Pomacea spp. in the Philippines. Review on levels of infestation, control methods, utilization and future research directions. Journal of Agriculture and Life Sciences 37(2), 7-32.

Carlsson, N., Kestrup, A., Martensson, M. and Nystrom, P. (2004a) Lethal and non-lethal effects of multiple indigenous predators on the invasive golden apple snail (Pomacea canaliculata). Freshwater Biology 49, 1269-1279. https://doi.org/10.1111/j.1365-2427.2004.01269.x

Carlsson, N.O.L., Brönmark, C. and Hansson, L.-A. (2004b) Invading herbivory: the golden apple snail alters ecosystem functioning in Asian wetlands. Ecology 85, 1575-1580.

https://doi.org/10.1890/03-3146 
Cazzaniga, N.J. (1990) Predation of Pomacea canaliculata (Ampullariidae) on adult Biomphalaria peregrina (Planorbidae). Annals of Tropical Medicine \& Parasitology 84, 97-100. https://doi.org/10.1080/00034983.1990.11812439

Cazzaniga, N.J. (2002) Old species and new concepts in the taxonomy of Pomacea (Gastropoda: Ampullariidae). Biocell 26, 71-81.

Cazzaniga, N.J. (2006) Pomacea canaliculata: harmless and useless in its natural realm (Argentina). In: Joshi, R.C. and Sebastian, L.S. (eds) Global Advances in Ecology and Management of Golden Apple Snails. Philippine Rice Research Institute, Nueva Ecija, Philippines, pp. 37-60.

Cazzaniga, N.J. and Estebenet, A.L. (1984) Revisión y notas sobre los hábitos alimentarios de los Ampullariidae (Gastropoda). Historia Natural 4, 213-224.

Cazzaniga, N.J. and Estebenet, A.L. (1985) A review of past work on the use of aquatic snails (Ampullariidae) in biological control programmes. Malezas 13(1), 23-39.

Chaichana, R. and Sumpan, T. (2014) The potential ecological impact of the exotic snail Pomacea canaliculata on the Thai native snail Pila scutata. Science Asia 40, 11-15. https://doi.org/10.2306/scienceasia1513-1874.2014.40.011

Chan, R., King-Lun, K. and Jian-Wen, Q. (2009) The potential of the invasive snail Pomacea canaliculata as a predator of various life-stages of five species of freshwater snails. Malacologia 51(2), 343-356.

Chang, W.-C. (1985) The ecological studies on the Ampullaria snails (Cyclophoracea: Ampullaridae [sic]). Bulletin of Malacology, Republic of China 11, 43-51.

Chanthy, P. (2002) Golden apple snails in Cambodia. In: Wada, T., Yusa, Y. and Joshi, R.C. (eds) Proceedings of the Meeting of the Special Working Group on the Golden Apple Snail (Pomacea spp.) at the Seventh International Congress on Medical and Applied Malacology. SEAMEO Regional Center for Graduate Study and Research in Agriculture, Los Baños, Laguna, Philippines. Available from: https://www.applesnail.net/pestalert/conferences/icam07/cambodia.htm (accessed 17 May 2021).

Cheng, E.Y. and Kao, C.-H. (2006) Control of golden apple snail Pomacea canaliculata (Lamarck), in Taiwan. In: Joshi, R.C. and Sebastian, L.S. (eds) Global Advances in Ecology and Management of Golden Apple Snails. Philippine Rice Research Institute, Nueva Ecija, Philippines, pp. 155167.

Coat, S., Monti, D., Legendre, P., Bouchon, C., Massat, F. and Lepoint, G. (2011) Organochlorine pollution in tropical rivers (Guadeloupe): role of ecological factors in food web bioaccumulation. Environmental Pollution 159(6), 1692-1701. http://dx.doi.org/10.1016/j.envpol.2011.02.036

Coelho, A.R., Calado, G.J.P., and Dinis, M.T. (2012) Freshwater snail Pomacea bridgesii (Gastropoda: Ampullariidae), life history traits and aquaculture potential. AACL Bioflux 5(3), 168-181. http://www.bioflux.com.ro/docs/2012.3.168-181.pdf

Collier, K.J., Demetras, N.J., Duggan, I.C. and Johnston, T.M. (2011) Wild record of an apple snail in the Waikato River, Hamilton, New Zealand, and their incidence in freshwater aquaria. New Zealand Natural Sciences 36, 1-9.

Cowie, R.H. (1995a) Report on a visit to Cambodia to advise on apple snails as potential rice pests. Report prepared for Cambodia-IRRI-Australia Project, Phnom Penh. Bishop Museum, Honolulu, 8 (+2) pp.

Cowie, R.H. (1995b) Identity, distribution and impacts of introduced Ampullariidae and Viviparidae in the Hawaiian Islands. Journal of Medical and Applied Malacology 5 [for 1993], 61-67.

Cowie, R.H. (2002) Apple snails (Ampullariidae) as agricultural pests: their biology, impacts and management. In: Barker, G.M. (ed.) Molluscs as Crop Pests. CAB International, Wallingford, UK, pp. 145-192. 
Cowie, R.H. (2011) Snails and slugs. In: Simberloff, D. and Rejmanek, M. (eds) Encyclopedia of Invasive Introduced Species. University of California Press, Berkeley, California, pp. 634-643.

Cowie, R.H. and Hayes, K.A. (2005) Invasive ampullariid snails: taxonomic confusion and some preliminary resolution based on DNA sequences. In: Lai, P.-Y., Chang, Y.F. and Cowie, R.H. (eds) Proceedings - APEC Symposium on the Management of the Golden Apple Snail, 6-11 September 2004. National Pingtung University of Science and Technology, Pingtung, Taiwan, pp. 7-16.

Cowie, R.H., Hayes, K.A. and Thiengo, S.C. (2006) What are apple snails? Confused taxonomy and some preliminary resolution. In: Joshi, R.C. and Sebastian, L.S. (eds) Global Advances in Ecology and Management of Golden Apple Snails. Philippine Rice Research Institute, Nueva Ecija, Philippines, pp. 3-23.

Cowie, R.H., Hayes, K.A, Tran, C.T. and Levin, P. (2007). Distribution of the invasive apple snail Pomacea canaliculate (Lamarck) in the Hawaiian Islands (Gastropoda: Ampullariidae). Bishop Museum Occasional Papers 96, 48-51.

Cowie, R.H., Hayes, K.A, Strong, E.E. and Thiengo, S.C. (2017) Non-native apple snails: systematics, distribution, invasion history and reasons for introduction. In: Joshi, R.C., Cowie, R.H. and Sebastian, L.S. (eds) Biology and Management of Invasive Apple Snails. Philippine Rice Research Institute, Nueva Ecija, Philippines, pp. 3-32.

Cummins, K.W. and Klug, M.J. (1979) Feeding ecology of stream invertebrates. Annual Review in Ecology and Systematics 10, 147-172. https://www.annualreviews.org/doi/abs/10.1146/annurev.es.10.110179.001051

Cuong, D.N. (2002) Golden apple snail (GAS) in Vietnam: introduction, impact and management. In: Wada, T., Yusa, Y. and Joshi, R.C. (eds) Proceedings of the Meeting of the Special Working Group on the Golden Apple Snail (Pomacea spp.) at the Seventh International Congress on Medical and Applied Malacology. SEAMEO Regional Center for Graduate Study and Research in Agriculture, Los Baños, Laguna, Philippines, pp. 49-54.

Cuong, D.N. (2006) The golden apple snail in Vietnam. In: Joshi, R.C. and Sebastian, L.S. (eds) Global Advances in Ecology and Management of Golden Apple Snails. Philippine Rice Research Institute, Nueva Ecija, Philippines, pp. 243-254.

Dai, J.-R., Wang, W., Liang, Y.-S., Li, H.-J., Guan, X.-H. and Zhu, Y.-C. (2008) A novel molluscicidal formulation of niclosamide. Parasitology Research 103, 405-412. https://doi.org/10.1007/s00436008-0988-2

Dancel, K.T. and Joshi, R.C. (2000) 'Golden' menace of Ifugao rice terraces. SEAFDEC Asian Agriculture 22(1), 11-12, 31-33.

Dela Cruz, M.S. and Joshi, R.C. (2001) Efficacy of commercial molluscicide formulations against the golden apple snail Pomacea canaliculata (Lamarck). Philippine Agricultural Scientist 84(1), 5155.

Dela Cruz, M.S., Joshi, R.C. and Martin, A.R. (2002) Golden apple snail damage in Philippine Seed Board rice varieties. International Rice Research Notes 27 (1),35-36. https://ejournals. ph/article. php?id=8474

Dela Cruz, M.S., Joshi, R.C. and Martin, A.R. (2003) Basal application of fertilizer reduces golden apple snail population. International Rice Research Notes 26(1), 20-21.

https://ejournals. ph/article. php?id=8373

Demetillo, M.T., Baguio, M.L., Limitares, D.E., Madjos, G.G. and Abrenica-Adamat, L.R. (2015) Effect of Cymbopogon citratus (lemon grass) crude leaf extracts on the developmental stages of Pomacea canaliculata (golden apple snail). Advances in Environmental Sciences 7, 460-467. 
Demian, E.S. and Lutfy, R.G. (1966) Factors affecting the predation of Marisa cornuarietis on Bulinus (B). truncatus, Biomphalaria alexandrina and Lymnaea caillaudi. Oikos 17(2), 212-230. https://doi.org/10.2307/3564945

Deng, P.Y., Shu, W.S., Lan, C.Y. and Liu, W. (2008) Metal contamination in the sediment, pondweed, and snails of a stream receiving effluent from a lead/zinc mine in Southern China. Bulletin of Environmental Contamination and Toxicology 81(1), 69-74. https://doi.org/10.1007/s00128-0089428-3

Dorta-Contreras, A.J., Padilla-Docal, B., Moreira, J.M., Robles, L.M., Aroca, J.M., et al. (2011) Neuroimmunological findings of Angiostrongylus cantonensis meningitis in Ecuadorian patients. Arquivos de Neuro-Psiquiatria 69(3), 466-469. https://doi.org/10.1590/s0004282x2011000400011

Douangboupha, B. and Khamphoukeo, K. (2006) Golden apple snail damage and management practices in rice farmers' fields in the Lao PDR. In: Joshi, R.C. and Sebastian, L.S. (eds) Global Advances in Ecology and Management of Golden Apple Snails. Philippine Rice Research Institute, Nueva Ecija, Philippines, pp. 275-280.

Dummee, V., Kruatrachue, M., Trinachartvanit, W., Tanhan, P., Pokethitiyook, P. and Damrongphol, P. (2012) Bioaccumulation of heavy metals in water, sediments, aquatic plant and histopathological effects on the golden apple snail in Beung Boraphet reservoir, Thailand. Ecotoxicology and Environmental Safety 86, 204-212. https://doi.org/10.1016/i.ecoenv.2012.09.018

Dreon, M.S., Fernández, P.E., Gimeno, E.J. and Heras, H. (2014) Insights into embryo defenses of the invasive apple snail Pomacea canaliculata: egg mass ingestion affects rat intestine morphology and growth. PLOS Neglected Tropical Diseases 8(6): e2961.

https://doi.org/10.1371/journal.pntd.0002961.

EFSA (European Food Safety Authority), Schrader, G., Delbianco, A. and Vos, S. (2020) Pest survey card on Pomacea spp. EFSA Supporting Publications 17(6): 1877E.

https://doi.org/10.2903/sp.efsa.2020.EN-1877

EFSA (European Food Safety Authority) Panel on Plant Health (2012) Scientific opinion on the evaluation of the pest risk analysis on Pomacea insularum, the island apple snail, prepared by the Spanish Ministry of Environment and Rural and Marine Affairs. EFSA Journal 10(1), 2552.

EFSA (European Food Safety Authority) Panel on Plant Health (2013) Scientific opinion on the assessment of the potential establishment of the apple snail in the EU. ESFA Journal 11(2), 3487. https://doi.org/10.2903/j.efsa.2013.3487

EFSA (European Food Safety Authority) Plant Health Newsletter (2020) Media Monitoring, No. 43, October 2020 EFSA-Q-2020-00069. https://doi.org/10.2903/sp.efsa.2020.EN-1943

Engelhardt, K.A.M. and Ritchie, M.E. (2001) Effect of macrophyte species richness on wetland ecosystem functioning and services. Nature 411(6838), 687-689.

https://doi.org/10.1038/35079573

Epa, U.P.K. (2006) Alien invasive snail, Pomacea sp., in Sri Lanka. In: Joshi, R.C. and Sebastian, L.S. (eds) Global Advances in Ecology and Management of Golden Apple Snails. Philippine Rice Research Institute, Nueva Ecija, Philippines, pp. 319-324.

EPCO (Environmental Protection and Conservation Organisation) (2020) Apple Snail Project. Environmental Protection and Conservation Organisation. Available at: https://epco.ngo/applesnail-project/ (accessed 20 August 2020).

EPPO (European and Mediterranean Plant Protection Organization) (2014) PQR database. European and Mediterranean Plant Protection Organization, Paris. Available at: http://www.eppo.int/DATABASES/pqr/pqr.htm (accessed 20 July 2020). 
Estebenet, A.L. and Martín, P.R. (2002) Pomacea canaliculata (Gastropoda: Ampullariidae): lifehistory traits and their plasticity. Biocell 26, 83-89.

Eversole, A.G. (1992) Golden Snail Problem on Rice: Report for Short- and Long-term Steps for Management. Report by the International Rice Research Institute (IRRI). IRRI, Los Baños, Philippines, 12 pp.

FAO (Food and Agriculture Organization of the United Nations) (1998) Fish farming in Vietnamese rice field fights golden apple snail pest. News and Highlights, FAO, Rome. Available at: http://www.fao.org/News/1998/980410-e.htm (accessed 14 August 2020).

FAO (Food and Agriculture Organization of the United Nations) (2019) FAOSTAT Database. Rome, Italy. Available at: http://www.fao.org/faostat/en/?\#data/QC (accessed 24 January 2020).

FAO (Food and Agriculture Organization of the United Nations) (2020) Crop Prospects and Food Situation - Quarterly Global Report No. 4, December. FAO, Rome.

Fischer, J.C. (1963) Les gastéropodes du 'continental intercalaire' du Sahara. In: Monginongin, D. and Fischer, J.-C. (eds) Les mollusques du 'continental intercalaire' (Mésozoïque) du Sahara central. Mémoires de la Société Géologique de France (Nouvelle Série) 42(96), 41-49, pls. 7-8.

Fontan Sers, C. and Mughal, M. (2020) Covid-19 outbreak and the need for rice self-sufficiency in West Africa. World Development 135: 105071.

Fujio, Y., Kurihara, H. and von Brand, E. (1991) Differences metric traits among three strains of apple snail, Pomacea canalicualta. Tohuku Journal of Agricultural Research 41(3-4), 61-68.

Future Agricultures (2020) COVID-19: coping strategies of rice value chain actors in Tanzania (1). Future Agricultures. Available at: https://www.future-agricultures.org/blog/covid-19-copingstrategies-of-rice-value-chain-actors-in-tanzania-1/ (accessed 14 November 2020).

GAIN (Global Alliance for Improved Nutrition) (2020) Impact of COVID-19 on Kenya's Food Systems Situation Report I. Global Alliance for Improved Nutrition. Available at:

https://www.gainhealth.org/index.php/resources/reports-and-publications/impact-covid-19kenyas-food-systems-situation-report-i (accessed 10 August 2020).

Gilal, A.A., Muhamad, R., Omar, D., Aziz, N.A.A. and Gnanasegaram, M. (2016) Foes can be friends: laboratory trials on invasive apple snails, Pomacea spp. preference to invasive weed, Limnocharis flava (L.) Buchenau compared to rice, Oryza sativa L. Pakistan Journal of Zoology 48(3), 673-679. Available at: https://apirs.plants.ifas.ufl.edu/site/assets/files/367474/367474.pdf (accessed 3 March 2021).

Gilioli, G., Pasquali, S., Martín, P.R., Carlsson, N. and Mariani, L. (2017) A temperature-dependent physiologically based model for the invasive apple snail Pomacea canaliculata. International Journal of Biometeorology 61, 1899-1911. https://doi.org/10.1007/s00484-017-1376-3

GISD (Global Invasive Species Database) (2021) Species Profile: Pomacea canaliculata. Global Invasive Species Database. Available at: http://www.iucngisd.org/gisd/species. php?sc=135 (accessed 3 April 2020).

Guo, J. and Zhang, J.-E. (2015) Status, problems and countermeasures in biological control of Pomacea canaliculata. Chinese Journal of Ecology 34, 2943-2950.

Halwart, M. (1994) The golden apple snail Pomacea canaliculata in Asian rice farming systems: present impact and future threat. International Journal of Pest Management 40, 199-206. https://doi.org/10.1080/09670879409371882

Halwart, M. (2006) Fish as biological control agents of golden apple snails in Philippine rice fields. In: Joshi, R.C. and Sebastian, L.S. (eds) Global Advances in Ecology and Management of Golden Apple Snails. Philippine Rice Research Institute, Nueva Ecija, Philippines, pp. 363-374. 
Halwart, M., Viray, M.C. and Kaule, G. (1998) Cyprinus carpio and Oreochromis niloticus as biological control agents of the golden apple snail Pomacea canaliculata - effects of predator size, prey size and prey density. Asian Fisheries Science 11, 31-42.

Halwart, M., Poethke, H.J. and Kaule, G. (2006) Golden snail population ecology in rice-fish culture and rice monoculture: a modeling approach. In: Joshi, R.C. and Sebastian, L.S. (eds) Global Advances in Ecology and Management of Golden Apple Snails. Philippine Rice Research Institute, Nueva Ecija, Philippines, pp. 375-392.

Halwart, M., Litsinger, J.A., Viray, M.C. and Kaule, G. (2014) Efficacy of common carp and Nile tilapia as biocontrol agents of the golden apple snail in the Philippines. Philippine Journal of Science 143(2), 125-136.

Hanifah, H.A.H.M., Hamdan, F.H., Ali, K.H.O., Jormasie, J., Besar, S.A.H.A., et al. (2018) Invasive apple snails (Pomacea spp.) in Brunei Darussalam: current status and management in irrigated transplanted rice fields. Aquaculture Asia Magazine 22(3), 23-25.

Hayes, K.A., Joshi, R.C., Thiengo, S.C. and Cowie, R.H. (2008) Out of South America: multiple origins of non-native apple snails in Asia: invasive ampullariids in Asia. Diversity and Distributions 14, 701-712. https://doi.org/10.1111/j.1472-4642.2008.00483.x

Hayes, K.A., Cowie, R.H. and Thiengo, S.C. (2009) A global phylogeny of apple snails: Gondwanan origin, generic relationships, and the influence of outgroup choice (Caenogastropoda: Ampullariidae): Ampullariid phylogeny. Biological Journal of the Linnean Society 98, 61-76. https://doi.org/10.1111/i.1095-8312.2009.01246.x

Hayes, K.A., Cowie, R.H., Thiengo, S.C. and Strong, E.E. (2012) Comparing apples with apples: clarifying the identities of two highly invasive Neotropical Ampullariidae (Caenogastropoda): anatomy and systematics of Ampullariids. Zoological Journal of the Linnean Society 166, 723753. https://doi.org/10.1111/j.1096-3642.2012.00867.x

Hayes, K.A., Burks, R.L., Castro-Vazquez, A., Darby, P.C., Heras, H., et al. (2015) Insights from an integrated view of the biology of apple snails (Caenogastropoda: Ampullariidae). Malacologia 58, 245-302. https://doi.org/10.4002/040.058.0209

Heiler, K.C.M., von Oheimb, P.V., Ekschmitt, K. and Albrecht, C. (2008) Studies on the temperature dependence of activity and on the diurnal activity rhythm of the invasive Pomacea canaliculata (Gastropoda: Ampullariidae). Mollusca 26(1), 73-81.

Hendarsih-Suharto, Marwoto, R.M., Heryanto, Mulyadi and Siwi, S.S. (2006) The golden apple snail, Pomacea spp., in Indonesia. In: Joshi, R.C. and Sebastian, L.S. (eds) Global Advances in Ecology and Management of Golden Apple Snails. Philippine Rice Research Institute, Nueva Ecija, Philippines, pp. 231-242.

Hoang, T.M.L., Tran, T.N., Nguyen, T.K.T., Williams, B., Wurm, P., Bellairs, S., et al. (2016) Improvement of salinity stress tolerance in rice: challenges and opportunities. Agronomy 6(4), p.54.

Hoeffler, D.F. (1974) Cercarial dermatitis, its etiology, epidemiology, and clinical aspects. Archives of Environmental Health 29(4), 225-229.

Hollingsworth, R.G. and Cowie, R.H. (2006) Apple snails as disease vectors. In: Joshi, R.C. and Sebastian, L.S. (eds) Global Advances in Ecology and Management of Golden Apple Snails. Philippine Rice Research Institute, Nueva Ecija, Philippines, pp. 121-132.

Horgan, F.G. (2017) Ecology and management of apple snails in rice. In: Chauhan, B.S., Jabran, K. and Mahajan, G. (eds) Rice Production Worldwide. Springer International Publishing, Cham, Switzerland, pp. 393-417. https://doi.org/10.1007/978-3-319-47516-5 15 
Horgan, F.G. (2018) The ecophysiology of apple snails in rice: implications for crop management and policy: apple snails in rice-production systems. Annals of Applied Biology 172, 245-267. https://doi.org/10.1111/aab.12424

Horgan, F.G., Stuart, A.M. and Kudavidanage, E.P. (2014) Impact of invasive apple snails on the functioning and services of natural and managed wetlands. Acta Oecologica 54, 90-100. https://doi.org/10.1016/j.actao.2012.10.002

Howells, R.G. and Smith, J.S. (2002) Status of the apple snail Pomacea canaliculata in the United States. In: Wada, T., Yusa, Y. and Joshi, R.C. (eds) Proceedings of the Meeting of the Special Working Group on the Golden Apple Snail (Pomacea spp.) at the Seventh International Congress on Medical and Applied Malacology. SEAMEO Regional Center for Graduate Study and Research in Agriculture, Los Baños, Laguna, Philippines, pp. 86-96.

Howells, R.G., Burlakova, L.E., Karatayev, A.Y., Marfurt, R.K. and Burks, R.L. (2006) Native and introduced Ampullariidae in North America: history, status, and ecology. In: Joshi, R.C. and Sebastian, L.S. (eds) Global Advances in Ecology and Management of Golden Apple Snails. Philippine Rice Research Institute, Nueva Ecija, Philippines, pp. 73-112.

Huan, N.H. and Joshi, R.C. (2002) Golden apple snail situation and integrated management activities in South Vietnam. In: Wada, T., Yusa, Y. and Joshi, R.C. (eds) Proceedings of the Meeting of the Special Working Group on the Golden Apple Snail (Pomacea spp.) at the Seventh International Congress on Medical and Applied Malacology. SEAMEO Regional Center for Graduate Study and Research in Agriculture, Los Baños, Laguna, Philippines, pp. 55-65.

Huang, H.-C., Liao, S.-C., Chang, F.-R., Kuo, Y.-H. and Wu, Y.-C. (2003) Molluscicidal saponins from Sapindus mukorossi, inhibitory agents of golden apple snails, Pomacea canaliculata. Journal of Agricultural and Food Chemistry 51, 4916-4919. https://doi.org/10.1021/jf0301910

Hylton-Scott, M.I. (1958) Estudio morfológico y taxonómico de los ampulláridos de la República Argentina. Revista del Museo Argentino de Ciencias Naturales 'Bernardino Rivadavia' 3, 233333.

Ichinose, K. (2002) Influence of age and body size on alarm responses in a freshwater snail Pomacea canaliculata. Journal of Chemical Ecology 28, 2017-2028. https://doi.org/10.1023/A:1020749911877

Ichinose, K. and Yoshida, K. (2001) Distribution of apple snails, related to rice field distribution and water flow. Kyushu Plant Protection Research 47, 77-81. https://doi.org/10.4241/kyubyochu.47.77

Ichinose, K., Tochihara, M., Wada, T., Suguiura, N. and Yusa, Y. (2002) Influence of common carp on apple snail in a rice field evaluated by a predator-prey logistic model. International Journal of Pest Management 48, 133-138. https://doi.org/10.1080/09670870110100703

Ip, K.K.L., Liang, Y., Lin, L., Wu, H., Xue, J. and Qiu, J.-W. (2014) Biological control of invasive apple snails by two species of carp: effects on non-target species matter. Biological Control 71, 16-22. https://doi.org/10.1016/j.biocontrol.2013.12.009

IRTA (Institute of Agrifood Research and Technology) (2020) The Neurice project has registered 6 salt-tolerant rice varieties. Institute of Agrifood Research and Technology. Available at: https://www.irta.cat/en/the-neurice-project-has-registered-6-salt-tolerant-rice-varieties/ (accessed 14 April 2021).

Ito, K. (2002) Environmental factors influencing overwintering success of the golden apple snail, Pomacea canaliculata (Gastropoda: Ampullariidae), in the northernmost population of Japan. Applied Entomology and Zoology 37, 655-661. https://doi.org/10.1303/aez.2002.655 
Jahn, G.C., Bunnarith, K., Sophea, P. and Chanty, P. (1997) Pest management in rice. In: Nesbitt, H.J. (ed.) Rice Production in Cambodia. International Rice Research Institute (IRRI), Manila, pp 83-91. http://books. irri.org/9712201007 content.pdf

Joshi, R.C. (2005a) Managing invasive alien mollusc species in rice. International Rice Research Notes 30, 5-13. http://books.irri.org/IRRN30no2 content.pdf

Joshi, R.C. (2005b) The golden apple snail: raiders of the rice fields. Outlooks on Pest Management 16(1), 23-26.

Joshi, R.C. (2007) Problems with the management of the golden apple snail Pomacea canaliculata: an important exotic pest of rice in Asia. In: Vreysen, M.J.B., Robinson, A.S. and Hendrichs, J. (eds) Area-wide Control of Insect Pests. Springer, Heidelberg, Germany pp. 257-264. https://link.springer.com/chapter/10.1007/978-1-4020-6059-5 24

Joshi, R.C. (2016) Golden apple snails continue to spread in Northern Spain. Agriculture for Development 27, 7-8.

Joshi, R.C. and Parera, X.V. (2017) The rice apple snail in Spain: a review. International Pest Control 59(2), 106-108.

Joshi, R.C. and Sebastian, L.S. (eds) (2006) Global Advances in Ecology and Management of Golden Apple Snails. Philippine Rice Research Institute, Nueva Ecija, Philippines, 600 pp.

Joshi, R.C., Dela Cruz, M.S., Martin, E.C., Cabigat, J.C., Bahatan, R.G., et al. (2001) Current status of the golden apple snail in the Ifugao rice terraces, Philippines. Journal of Sustainable Agriculture 18, 71-90. https://doi.org/10.1300/J064v18n02 07

Joshi, R.C., Dela Cruz, M.S., Martin, A.R., Duca, A.V. and Martin, E.C. (2002) Relation of golden apple snail size to rice seedling damage in transplanted and direct-seeded rice cultivation. International Rice Research Newsletter 27(1), 37-38.

Joshi, R.C., Baucas, N.S., Joshi, E.E. and Verzola, E.A. (2003) Scientific Information Database on Golden Apple Snail (Pomacea spp.). CD-ROM. Department of Agriculture-Cordillera Administrative Region, Department of Agriculture Philippine Rice Research Institute (DAPhilRice), DA-Cordillera Highland Agricultural Resource Management Project (CHARM), Agricultural Librarians Association of the Philippines (ALAP), Baguio City, Philippines. ISBN 97192558-7-0.

Joshi, R.C., Desamito, M.S., Martin, A.R., Sebastian, L.S. and Coupland, J.B. (2004) Detrimental effects of niclosamide $250 \mathrm{EC}$ at preseeding in direct-seeded rice culture. International Rice Research Notes 29(2), 36-37. https://ejournals.ph/article.php?id=8641

Joshi, R.C., Meepagala, K.M., Sturtz, G., Cagauan, A.G., Mendoza, C.O., et al. (2005) Molluscicidal activity of vulgarone $B$ from Artemisia douglasiana (Besser) against the invasive, alien, mollusc pest, Pomacea canaliculata (Lamarck). International Journal of Pest Management 51, 175-180. https://doi.org/10.1080/09670870500183161

Joshi, R.E. (2005) Off-season Mortality of Golden Apple Snail, Pomacea canaliculata (Lamarck) and its Management Implications. University Science High School, Central Luzon State University, Science City of Muñoz, Nueva Ecija, Philippines, 75 pp.

Kaloi, F.K., Isaboke, H.N., Onyari, C.N. and Njeru, L.K. (2020) Comparing productivity of rice under system of rice intensification and conventional flooding: a switching regression approach. African Journal of Agricultural Research 16(10), 1355-1363.

Kappes, H. and Haase, P. (2012) Slow, but steady: dispersal of freshwater molluscs. Aquatic Sciences 74, 1-14. https://doi.org/10.1007/s00027-011-0187-6

Keawjam, R.S. (1986) The apple snails of Thailand: distribution, habitats and shell morphology. Malacological Review 19, 61-81. 
Keawjam, R.S. and Upatham, E.S. (1990) Shell morphology, reproductive anatomy and genetic patterns of three species of apple snails of the genus Pomacea in Thailand. Journal of Medical and Applied Malacology 2, 49-62.

Keller, R.P., Drake, J.M. and Lodge, D.M. (2007) Fecundity as a basis for risk assessment of nonindigenous freshwater molluscs. Conservation Biology 21, 191-200.

https://doi.org/10.1111/j.1523-1739.2006.00563.x

Ketelaar, J.W.H. (1993) Strategies for solving the Philippine snail problem: a system perspective. MSc thesis, Wageningen Agricultural University, Wageningen, The Netherlands, $100 \mathrm{p}$.

Khay, S., Joshi, R.C. and Sastroutomo, S.S. (2018) Invasive apple snails: integrated management in lowland ricefields of Cambodia and probing their utilization in aquaculture. Fish for the People 16(3), 34-37.

Köhler, F., Seddon, M., Bogan, A.E., Do, V.T., Sri-Aroon, P. and Allen, D. (2012) The status and distribution of freshwater molluscs of the Indo-Burma region. In: Allen, D.G., Smith, K.G. and Darwall, W.R.T. (eds) The Status and Distribution of Freshwater Biodiversity in Indo-Burma. IUCN, Cambridge, UK and Gland, Switzerland, 66-89.

Kioko, W.F., Mawia, M.A. and Piero, N.M. (2015) Phenotypic characterization on selected Kenyan and Tanzanian rice (Oryza sativa $L$ ) populations based on grain morphological traits. Rice Research 3, 155. https://doi.org/10.4172/2375-4338.1000155

Komalamisra, C., Nuamtanong, S. and Dekumyoy, P. (2009) Pila ampullacea and Pomacea canaliculata, as new paratenic hosts of Gnathostoma spinigerum. Southeast Asian Journal of Tropical Medicine and Public Health 40(2), 243-246.

Kondo, A. and Tanaka, F. (1989) An experimental study of predation by the larvae of the firefly, Luciola lateralis Motschulsky (Coleoptera: Lampyridae) on the apple snail, Pomacea canaliculata Lamarck (Mesogastropoda: Pilidae). Japanese Journal of Applied Entomology and Zoology 33, 211-216.

Kruatrachue, M., Sumritdee, C., Pokethitiyook, P. and Singhakaew, S. (2011) Histopathological effects of contaminated sediments on golden apple snail (Pomacea canaliculata, Lamarck 1822). Bulletin of Environmental Contamination and Toxicology 86, 610-614.

Kristensen, T.K. and Brown, D.S. (1999) Control of intermediate host snails for parasitic diseases - a threat to biodiversity in African freshwaters? Malacologia 41(2), 379-391. https://www.sciencebase.gov/catalog/item/5054054be4b097cd4fcfb075

Kwong, K.-L., Wong, P.-K., Lau, S.S.S. and Qiu, J.-W. (2008) Determinants of the distribution of apple snails in Hong Kong two decades after their initial invasion. Malacologia 50, 293-302. https://doi.org/10.4002/0076-2997-50.1.293

Kwong, K.-L., Chan, R.K.Y. and Qiu, J.-W. (2009) The potential of the invasive snail Pomacea canaliculata as a predator of various life-stages of five species of freshwater snails. Malacologia 51, 343-356. https://doi.org/10.4002/040.051.0208

Kwong, K.L., Dudgeon, D., Wong, P.K. and Qiu, J.-W. (2010) Secondary production and diet of an invasive snail in freshwater wetlands: implications for resource utilization and competition. Biological Invasions 12, 1153-1164. https://doi.org/10.1007/s10530-009-9537-x

Kyle, C.H., Plantz, A.L., Shelton, T. and Burks, R.L. (2013) Count your eggs before they invade: identifying and quantifying egg clutches of two invasive apple snail species (Pomacea). PLoS ONE 8(10): e77736. https://doi.org/10.1371/journal.pone.0099149.

Lach, L., Britton, D.K., Rundell, R.J. and Cowie, R.H. (2000) Food preference and reproductive plasticity in an invasive freshwater snail. Biological Invasions 2, 279-288.

https://doi.org/10.1023/A:1011461029986 
Lai, P.-Y., Chang, Y.F. and Cowie, R.H. (eds) (2005) Proceedings - APEC Symposium on the Management of the Golden Apple Snail, 6-11 September 2004. National Pingtung University of Science and Technology, Pingtung, Taiwan, 153 pp.

Latip, S.N.H.M., Hajjar, S.N., Maznah, M. and Keni, M. (2013). Azadirachta indica extract as biopesticide for controlling golden apple snail, Pomacea canaliculata. Advanced Science Letters. 19, 2992-2994. Doi: 10.1166/asl.2013.5093

Latip, S.N.H.M., Nawi, F.W.M. and Mansur, S.H.P. (2017) Potential of selected indigenous plant extracts as botanical pesticides for controlling golden apple snail, Pomacea canaliculata. In: Yap, C.K. (ed.) Snails: Biodiversity, Biology and Behavioral Insights. Nova Science Publishers, New York, pp. 95-116.

Lee, S.B., Lee, S.M., Park, C.B., Lee, C.R., Ko, B.G., et al. (2019) The environmental adaptability of Pomacea canaliculata used for weed control in wet rice paddies and crop damage caused by overwintered golden apple snails. Korean Journal of Environmental Agriculture 38, 23-33. https://doi.org/10.5338/KJEA.2019.38.1.1

Lee, T.-G. and Oh, K.C. (2006) Golden apple snails in Korea. In: Joshi, R.C. and Sebastian, L.S. (eds) Global Advances in Ecology and Management of Golden Apple Snails. Philippine Rice Research Institute, Nueva Ecija, Philippines, pp. 516-525.

Leedom, W.S. and Short, R.B. (1981) Ceracria pomaceae sp. n., a dermatitis-producing schistosome cercaria from Pomacea paludosa, the Florida apple snail. Journal of Parasitology 67(2), 257-261.

Lei, J., Chen, L. and Li, H. (2017) Using ensemble forecasting to examine how climate change promotes worldwide invasion of the golden apple snail (Pomacea canaliculata). Environmental Monitoring and Assessment 189, 404. https://doi.org/10.1007/s10661-017-6124-y

Levin, P. (2006) Statewide Strategic Control Plan for Apple Snail (Pomacea canaliculata) in Hawai'i. The Hawai'i Land Restoration Institute, Wailuku, Hawai'i, USA, 182 pp.

Levin, P., Cowie, R.H., Taylor, J.M., Hayes, K.A., Burnett, K.M. and Ferguson, C.A. (2006) Apple snail invasions and the slow road to control: ecological, economic, agricultural and cultural perspectives in Hawaii. In: Joshi, R.C. and Sebastian, L.S. (eds) Global Advances in Ecology and Management of Golden Apple Snails. Philippine Rice Research Institute, Nueva Ecija, Philippines, pp. 325-335.

Linares, O.F. (2002) African rice (Oryza glaberrima): history and future potential. Proceedings of the National Academy of Sciences 99, 16360-16365. https://doi.org/10.1073/pnas.252604599

Litsinger, J.A. and Estano, D.B. (1993) Management of the golden apple snail Pomacea canaliculata (Lamarck) in rice. Crop Protection 12, 363-370. https://doi.org/10.1016/0261-2194(93)90079-X

Loctier, D. and Hackwill, R. (2018) Scientists try seawater to save Europe's rice from rapacious invasive snail. Euronews. Available at: https://www.euronews.com/2018/10/01/scientists-tryseawater-to-save-europe-s-rice-from-rapacious-invasive-snail (accessed 14 April 2021).

López, M.A., Altaba, C.R., Andree, K.B. and López, V. (2010) First invasion of the apple snail Pomacea insularum in Europe. Tentacle - The Newsletter of the IUCN/SSC Mollusc Specialist Group 1, 26-28.

Lv, S., Zhou, X.N., Zhang, Y., Liu, H.X., Zhu, D., Yin, W.G., Steinmann, P, Wang, X.H. and Jia, T.W. (2006) The effect of temperature on the development of Angiostrongylus cantonensis (Chen 1935) in Pomacea canaliculata (Lamarck 1822). Parasitology Research 99, 583-587.

Lv, S., Zhang, Y., Steinmann, P., Yang, G.-J., Yang, K., et al. (2011) The emergence of angiostrongyliasis in the People's Republic of China: the interplay between invasive snails, climate change and transmission dynamics: emerging angiostrongyliasis in China. Freshwater Biology 56, 717-734. https://doi.org/10.1111/j.1365-2427.2011.02579.x 
Maketon, M., Suttichart, K. and Domhom, J. (2009) Effective control of invasive apple snail (Pomacea canaliculata Lamarck) using Paecilomyces lilacinus (Thom) Samson. Malacologia 51, 181-190.

Manara, E., Saveanu, L. and Martín, P.R. (2016) Effects of ingestion of lithic particles on growth of the apple snail Pomacea canaliculate (Caenogastropoda, Ampullariidae). Malacologia 59, 211-222.

Martin, C.W., Bahya, K.M. and Valentine, J.F. (2012) Establishment of the invasive island apple snail Pomacea insularum (Gastropoda: Ampullaridae) and eradication efforts in Mobile, Alabama, USA. Gulf of Mexico Science 30(1), 30-38. https://doi.org/10.18785/goms.3001.05

Martín, P.R. and De Francesco, G.C. (2006) Fossil record of Pomacea (Caenogastropoda: Ampullariidae) in Argentina and its paleoenvironmental implications. Biocell 30(2), 337-343.

Martín, P.R., Estebenet, A.L. and Cazzaniga, N.J. (2001) Factors affecting the distribution of Pomacea canaliculata (Gastropoda: Ampullariidae) along its southernmost natural limit. Malacologia 43, 13-23.

Martín, P.R., Burela, S., Seuffert, M.E., Tamburi, N.E. and Saveanu, L. (2019) Invasive Pomacea snails: actual and potential environmental impacts and their underlying mechanisms. $C A B$ Reviews 14(42), 11 pp. https://doi.org/10.1079/PAVSNNR201914042

Marwoto, R.M., Isnaningsih, N.R. and Joshi, R.C. (2018) The invasive apple snail (Pomacea spp.) in Indonesia. Agriculture for Development 35, 41-48. https://www.cabi.org/isc/FullTextPDF/2019/20193044933.pdf.

Mati, B.M., Wanjogu, R., Odongo, B. and Home, P.G. (2011) Introduction of the system of rice intensification in Kenya: experiences from Mwea Irrigation Scheme. Paddy Water Environment 9, 145-154. https://doi.org/10.1007/s10333-010-0241-3

Matsukura, K. and Wada, T. (2017) Identification of Pomacea species using molecular techniques. In: Joshi, R.C., Cowie, R.H. and Sebastian, L.S. (eds) Biology and Management of Invasive Apple Snails. Philippine Rice Research Institute, Nueva Ecija, Philippines, pp. 33-43.

Matsukura, K., Okuda, M., Kubota, K. and Wada, T. (2008) Genetic divergence of the genus Pomacea (Gastropoda: Ampullariidae) distributed in Japan, and a simple molecular method to distinguish P. canaliculata and P. insularum. Applied Entomology and Zoology 43, 535-540. https://doi.org/10.1303/aez.2008.535

Matsukura, K., Tsumuki, H., Izumi, Y. and Wada, T. (2009) Physiological response to low temperature in the freshwater apple snail, Pomacea canaliculata (Gastropoda: Ampullariidae). Journal of Experimental Biology 212(16), 2558-2563.

Matsukura, K., Okuda, M., Cazzaniga, N.J. and Wada, T. (2013) Genetic exchange between two freshwater apple snails, Pomacea canaliculata and Pomacea maculata invading East and Southeast Asia. Biological Invasions 15, 2039-2048. https://doi.org/10.1007/s10530-013-0431-1

Matsukura, K., Izumi, Y., Yoshida, K. and Wada, T. (2016) Cold tolerance of invasive freshwater snails, Pomacea canaliculata, P. maculata, and their hybrids helps explain their different distributions. Freshwater Biology 61, 80-87. https://doi.org/10.1111/fwb.12681

Medrano, F.G., Canapi, B.L., Olivares, F.M.J., Sagun, V.C., Estoy, G.F., et al. (1993) Barangay IPM Project in Irrigated Rice in Nueva Ecija, Philippines, Maximizing the Need for Wet Season Insecticides Treatments. Joint Report of PhilRice, International Rice Research Institute (IRRI), Department of Agriculture (DA) and Food and Agriculture Organization of the United Nations FAO, Manila, IRRI 22. Philippine Department of Agriculture/FAO, Manila, 25 pp.

Miller, C.L., Kinsella, J.M., Garner, M.M., Evans, S., Gullett, P.A. and Schmidt, R.E. (2006) Endemic infections of Parastrongylus (=Angiostrongylus) costaricensis in two species of nonhuman primates, raccoons, and an opossum from Miami, Florida. Journal of Parasitology 92, 406-408. https://doi.org/10.1645/GE-653R.1 
Mochida, O. (1991) Spread of freshwater Pomacea snails (Pilidae, Mollusca) from Argentina to Asia. Micronesica Supplement 3, 51-62.

Mohanty, S., Wassmann, R., Nelson, A., Moya, P. and Jagadish, S.V.K. (2013) Rice and Climate Change: Significance for Food Security and Vulnerability. IRRI Discussion Paper Series No. 49. International Rice Research Institute, Los Baños, Philippines, 14 pp.

Morallo-Rejesus, B., Sayaboc, A.S. and Joshi, R.C. (1989) The distribution and control of the introduced golden snail (Pomacea spp.) in the Philippines. In: Jalil, A.W., Manalo, P.L., Sastroutomo, S.S., Ganapathi, A., Chan, K.C., et al. (eds) Introduction of Germplasm and Plant Quarantine Procedures. PLANTI Proceedings No. 4, Asean Planti, Kuala Lumpur, pp. 213-223.

Morrison, W.E. and Hay, M.E. (2011) Herbivore preference for native vs. exotic plants: generalist herbivores from multiple continents prefer exotic plants that are evolutionarily naïve. PLOS ONE 6: e17227. https://doi.org/10.1371/journal.pone.0017227

Mu, H., Sun, J., Fang, L., Luan, T., Williams, G.A., et al. (2015) Genetic basis of differential heat resistance between two species of congeneric freshwater snails: insights from quantitative proteomics and base substitution rate analysis. Journal of Proteome Research 14, 4296-4308. https://doi.org/10.1021/acs.jproteome.5b00462

Myint, K.K.M. and Ye, K.N. (2017) Apple snails (Pomacea spp.) in Myanmar: current status and integrated management activities. In: Joshi, R.C., Cowie, R.H. and Sebastian, L.S. (eds) Biology and Management of Invasive Apple Snails. Philippine Rice Research Institute, Nueva Ecija, Philippines, pp. 209-211.

Nanfumba, D., Turyahabwe, N., Ssebuliba, J.W., Kakuru, W., Kaugule, J., et al. (2013) Participatory identification of farmer acceptable improved rice varieties for rain-fed lowland ecologies in Uganda. African Crop Science Journal 21(3), 683-691.

Naylor, R. (1996) Invasions in agriculture: assessing the cost of the golden apple snail in Asia. Ambio 25, 443-448.

Ndiiri, J.A., Mati, B.M., Home, P.G. and Odongo, B. (2013) Water productivity under the system of rice intensification from experimental plots and farmer surveys in Mwea, Kenya. Taiwan Water Conservancy 61, 63-75.

NEURICE (New commercial EUropean RICE) (2016) Available at: http://neurice.eu/ (accessed 3 March 2021).

Ng, T.H., Tan, S.K., Ahmad, A., Do, V., Joshi, R., Wang, W., Tan, H. and Yeo, D. (2019) Not in the least concern: anthropogenic influences on a South-east Asian apple snail Pila scutata (Ampullariidae). Oryx 53(2), 230-238. https://doi.org/10.1017/S0030605318000443

Nghiem, L.T.P., Soliman, T., Yeo, D.C.J., Tan, H.T.W., Evans, T.A., et al. (2013) Economic and environmental impacts of harmful non-indigenous species in Southeast Asia. PLoS ONE 8: e71255. https://doi.org/10.1371/journal.pone.0071255

Ngige, K.J. (2004) An economic analysis of rice production in Mwea Irrigation Scheme. Masters thesis, University of Nairobi, Kenya, 130 pp.

Ngoc, K.H. (2002) Golden apple snail in Viet Nam. In: Wada, T., Yusa, Y. and Joshi, R.C. (eds) Proceedings of the Meeting of the Special Working Group on the Golden Apple Snail (Pomacea spp.) at the Seventh International Congress on Medical and Applied Malacology. SEAMEO Regional Center for Graduate Study and Research in Agriculture, Los Baños, Laguna, Philippines, pp. 39-48.

Norman, J.C. and Otoo, E. (2003) Rice development strategies for food security in Africa. In: Proceedings of the 20th Session of the International Rice Commission. Bangkok, Thailand, 23-26 July 2002. Sustainable Rice Production for Food Security. Food and Agriculture Organization of the United Nations, Rome, pp. 235-250. 
Nugaliyadde, L., Jayasundera, D.M., Amarasinghe, A.A.L., Yusa, Y. and Hidaka, T. (2001) Distribution of an alien snail, Pomacea bridgesii, in fresh water habitats and its potential threat to faunal diversity and rice cultivation in Sri Lanka. Annals of the Sri Lanka Department of Agriculture 3, 375-376.

Ochoa Chumaña, L.A. and García Onofre, J.A. (2012) Determinación de la actividad molusquicida de dos extractos vegetales sobre caracol manzana (Pomacea canaliculata) y su impacto en la diversidad de artrópodos. Tesis de grado ingenieros Agrícolas y biológicos, Escuela Superior Politécnica del Litoral, Guayaquil, Ecuador, 66 pp. + appendix.

http://www.dspace.espol.edu.ec/handle/123456789/21123

Okuma, M., Tanaka, K. and Sudo, S. (1994) Weed control method using apple snail (Pomacea canaliculata) in paddy fields. Journal of Weed Science and Technology 39, 114-119. https://doi.org/10.3719/weed.39.114

Onyango, A.M. (2014) Exploring options for improving rice production to reduce hunger and poverty in Kenya. World Environment 4, 172-179.

Orapa, W. (2006) Golden apple snail in Papua New Guinea. In: Joshi, R.C. and Sebastian, L.S. (eds) Global Advances in Ecology and Management of Golden Apple Snails. Philippine Rice Research Institute, Nueva Ecija, Philippines, pp. 528-529.

Ozawa, A. and Makino, T. (1989) Biology of the apple snail, Pomacea canaliculata (Lamarck), and its control. Shokubutsu Boeki 43, 502-505.

Ozawa, A., Makino, A. and Isigami, S. (1989) A predator of adults of the apple snail, Pomacea canaliculata (Lamarck), a species of leech, Whitmania pigra. Proceedings of the Kanto-Tosan Plant Protection Society 36, 214.

PCPB (Pest Control Products Board) (2021) Available at: https://www.pcpb.go.ke/crops/ (accessed 25 February 2021).

Peña, S. C. (2017) Accumulation of copper and other elements by the apple snail Pomacea canaliculata. In: Joshi, R.C., Cowie, R.H. and Sebastian, L.S. (eds) Biology and Management of Invasive Apple Snails. Philippine Rice Research Institute, Nueva Ecija, Philippines, pp. 133-144.

PhilRice (Philippine Rice Research Institute) (2001) Management options for the golden apple snail. Rice Technology Bulletin 33, 16 pp.

Pilsbry, H.A. and Bequaert, J.T. (1927) The aquatic mollusks of the Belgian Congo: with a geographical and ecological account of Congo malacology. Bulletin of the American Museum of Natural History 53(2), 69-602, pl. 10-77. https://www.biodiversitylibrary.org/bibliography/89118

Pimentel, D., Lach, L., Zuniga, R. and Morrison, D. (2000) Environmental and economic costs of nonindigenous species in the United States. BioScience 50, 53. https://doi.org/10.1641/00063568(2000)050[0053:EAECON]2.3.CO;2

Pizani, N.V., Estebenet, A.L. and Martín, P.R. (2005) Effects of submersion and aerial exposure on clutches and hatchlings of Pomacea canaliculata (Gastropoda: Ampullariidae). American Malacological Bulletin 20(1-2), 55-63.

Prashad, B. (1925) Anatomy of the common Indian apple-snail, Pila globosa. Memoirs of the Indian Museum 8, 91-151.

Preap, V., Chanty, P., Bunnarith, K. and Hin, K. (2006) The golden apple snail situation in Cambodia. In: Joshi, R.C. and Sebastian, L.S. (eds) Global Advances in Ecology and Management of Golden Apple Snails. Philippine Rice Research Institute, Nueva Ecija, Philippines, pp. 267-274.

Qiu, J.-W., Chan, M.T., Kwong, K.L. and Sun, J. (2011) Consumption, survival and growth in the invasive freshwater snail Pomacea canaliculata: does food freshness matter? Journal of Molluscan Studies 77, 189-195. https://doi.org/10.1093/mollus/eyr005 
Ramírez, R., Paredes, C. and Arenas, J. (2003) Moluscos del Perú. Revista de Biología Tropical 51(3), 225-284.

Ranamukhaarachchi, S.L. and Wikramasinghe, S. (2006) Golden apple snails in the world: introduction, impact, and control measures. In: Joshi, R.C. and Sebastian, L.S. (eds) Global Advances in Ecology and Management of Golden Apple Snails. Philippine Rice Research Institute, Nueva Ecija, Philippines, pp. 133-151.

Rawlings, T.A., Hayes, K.A., Cowie, R.H. and Collins, T.M. (2007) The identity, distribution, and impacts of non-native apple snails in the continental United States. BMC Evolutionary Biology 7 , 97. https://doi.org/10.1186/1471-2148-7-97

Reilly, S.A. (2017) Forecasting the spread and invasive potential of apple snails (Pomacea spp.) in Florida. Master's thesis, Nova Southeastern University, Broward County, Florida, 78 p. Available at: https://nsuworks. nova.edu/occ stuetd/460 (accessed 15 March 2021).

Revillia, I.M., Estoy, G.F. and Salazar, F.V. (1991) State of Golden Kuhol infestation in selected rice farming villages in Nueva Ecija. In: Report of a Workshop on the Management of Golden Snail in the Philippines. Philippine Rice Research Institute, Nueva Ecija, Philippines, pp. 36-59.

Rice for Africa (2019) Tanzania, June 2019. Rice for Africa. Available at: https://riceforafrica.net/cardcountries/group-1-countries/tanzania/tanzania,-june-2019 (accessed 1 June 2020).

Rice for Africa (2020) Kenya, Oct 2020. Rice for Africa. Available at: https://riceforafrica.net/cardcountries/group-1-countries/kenya/kenya,-oct-2020 (accessed 14 April 2021).

Rice for Africa (2021) National Rice Development Strategy by CARD member countries. Rice for Africa. Available at: https://riceforafrica.net/nrds-page (accessed 14 April 2021).

Rodriguez, M.C., Espinosa, E. and Rodriguez, M.C. (2017) Pomacea canaliculata in Ecuador: a recent pest with multiple implications. In: Joshi, R.C., Cowie, R.H. and Sebastian, L.S. (eds) Biology and Management of Invasive Apple Snails. Philippine Rice Research Institute (PhilRice), Nueva Ecija, Philippines, pp. 257-291.

Rosario, J. and Moquete, C. (2006) The aquatic snail Ampullaria canaliculata L. - plague of irrigated lowland rice in the Dominican Republic. In: Joshi, R.C. and Sebastian, L.S. (eds) Global Advances in Ecology and Management of Golden Apple Snails. Philippine Rice Research Institute, Nueva Ecija, Philippines, pp. 514-515.

Salcedo, G.A. (2013) Pathogenic action of Heterorhabditis bacteriophora (Poinar) on apple snail (Pomacea canaliculata Lamarck), pest of rice (Oryza sativa) in the lower river basin Daule, Guayas, Ecuador. Avances en Investigación Agropecuaria 17(2), 53-56.

Salleh, N.H.M., Arbain, D., Daud, M.Z.M., Pilus, N. and Nawi, R. (2012) Distribution and management of Pomacea canaliculata in the Northern Region of Malaysia: mini review. APCBEE Procedia 2, 129-134. https://doi.org/10.1016/j.apcbee.2012.06.024

Samejima, H., Katsura, K., Kikuta, M., Njinju, S.M., Kimani, J.M., et al. (2020) Analysis of rice yield response to various cropping seasons to develop optimal cropping calendars in Mwea, Kenya. Plant Production Science 23, 297-305. https://doi.org/10.1080/1343943X.2020.1727752

Sanico, A.L., Peng, S., Laza, R.C. and Visperas, R.M. (2002) Effect of seedling age and seedling number per hill on snail damage in irrigated rice. Crop Protection 21, 137-143. https://doi.org/10.1016/S0261-2194(01)00075-8

San Martín, R., Ndjoko, K. and Hostettmann, K. (2008) Novel molluscicide against Pomacea canaliculata based on quinoa (Chenopodium quinoa) saponins. Crop Protection 27, 310-319. https://doi.org/10.1016/j.cropro.2007.03.015 
Santos, C.A.Z., Penteado, C.H.S. and Mendes, E.G. (1987) The respiratory responses of an amphibious snail Pomacea lineata (spix, 1827), to temperature and oxygen tension variations. Comparative Biochemistry and Physiology Part A: Physiology 86, 409-415.

https://doi.org/10.1016/0300-9629(87)90516-0

Satoyama, T., Sourang, C.M. and Bartoloni, R. (2014) Getting to Scale with Successful Experiences in Rice Sector Development in Africa: Best Practices and Scalability Assessments. Secretariat of Coalition for African Rice Development (CARD), Nairobi, Kenya, 106 pp.

Savaya-Alkalay, A., Ovadia, O., Barki, A. and Sagi, A. (2018) Size-selective predation by all-male prawns: implications for sustainable biocontrol of snail invasions. Biological Invasions 20, 137149. https://doi.org/10.1007/s10530-017-1522-1

Saveanu, L. and Martín, P.R. (2013) Pedal surface collecting as an alternative feeding mechanism of the invasive apple snail Pomacea canaliculata (Caenogastropoda: Ampullariidae). Journal of Molluscan Studies 79, 11-18. https://doi.org/10.1093/mollus/eys030

Saveanu, L. and Martín, P.R. (2015) Neuston: a relevant trophic resource for apple snails? Limnologica 52, 75-82. https://doi.org/10.1016/j.limno.2015.03.005

Saveanu, L., Manara, E. and Martín, P.R. (2017) Carrion consumption and its importance in a freshwater trophic generalist: the invasive apple snail Pomacea canaliculata. Marine and Freshwater Research 68, 752. https://doi.org/10.1071/MF15304

Schneiker, J., Weisser, W.W., Settele, J., Nguyen, V.S., Bustamante, J.V., et al. (2016) Is there hope for sustainable management of golden apple snails, a major invasive pest in irrigated rice? NJAS - Wageningen Journal of Life Sciences 79, 11-21. https://doi.org/10.1016/j.njas.2016.07.001

Schnorbach, H.J. (1995) The golden apple snail (Pomacea canaliculata Lamarck), an increasingly important pest in rice, and methods of control with Bayluscid ${ }^{\circledR}$. Pflanzenschutz-Nachrichten Bayer 48, 313-346.

Schnorbach, H.J., Rauen, H.W. and Bieri, M. (2006) Chemical control of the golden apple snail, Pomacea canaliculata. In: Joshi, R.C. and Sebastian, L.S. (eds) Global Advances in Ecology and Management of Golden Apple Snails. Philippine Rice Research Institute, Nueva Ecija, Philippines, pp. 419-438.

Senthilkumar, K., Tesha, B.J., Mghase, J. and Rodenburg, J. (2018) Increasing paddy yields and improving farm management: results from participatory experiments with good agricultural practices (GAP) in Tanzania. Paddy Water Environment 16, 749-766. https://doi.org/10.1007/s10333-018-0666-7

Seuffert, M.E. and Martín, P.R. (2010) Dependence on aerial respiration and its influence on microdistribution in the invasive freshwater snail Pomacea canaliculata (Caenogastropoda, Ampullariidae). Biological Invasions 12, 1695-1708. https://doi.org/10.1007/s10530-009-9582-5

Seuffert, M.E. and Martín, P.R. (2013) Juvenile growth and survival of the apple snail Pomacea canaliculata (Caenogastropoda: Ampullariidae) reared at different constant temperatures. SpringerPlus 2, 312. https://doi.org/10.1186/2193-1801-2-312

Seuffert, M.E., Burela, S. and Martín, P.R. (2010) Influence of water temperature on the activity of the freshwater snail Pomacea canaliculata (Caenogastropoda: Ampullariidae) at its southernmost limit (Southern Pampas, Argentina). Journal of Thermal Biology 35, 77-84. https://doi.org/10.1016/j.jtherbio.2009.11.003

Shivambu, T., Shivambu, N. and Downs, C. (2020) Exotic gastropods for sale: an assessment of land and aquatic snails in the South African pet trade. Management of Biological Invasions 11, 512524. https://doi.org/10.3391/mbi.2020.11.3.11 
Sin, T.S. (2003) Damage potential of the golden apple snail Pomacea canaliculata (Lamarck) in irrigated rice and its control by cultural approaches. International Journal of Pest Management 49, 49-55. https://doi.org/10.1080/713867835

Sisa, M.H., Aspani, F., Massaguni, R., Awang Damit, H. and Joseph, H. (2016) Inhibition of egg hatching of the golden apple snail by synthetic molluscicides. In: Yacob, N., Mohamed, M. and Megat Hanafiah, M. (eds) Regional Conference on Science, Technology and Social Sciences (RCSTSS 2014). Springer, Singapore, pp 463-471. https://doi.org/10.1007/978-981-10-0534346

Smith, B.D. (1992) Introduction and dispersal of apple snails (Ampullariidae) on Guam. Pacific Science Association Information Bulletin 44(1/2), 12-14.

Smith, J.W. (2006) Ampullariidae pathways. In: Joshi, R.C. and Sebastian, L.S. (eds) Global Advances in Ecology and Management of Golden Apple Snails. Philippine Rice Research Institute, Nueva Ecija, Philippines, pp. 113-120.

Snyder, N.F.R. and Snyder, H.A. (1971) Defenses of the Florida apple snail Pomacea paludosa. Behaviour 40, 175-215. https://doi.org/10.1163/156853971X00384

Soullier, G., Demont, M., Arouna, A., Lançon, F. and Mendez del Villar, P. (2020) The state of rice value chain upgrading in West Africa. Global Food Security 25, 100365.

https://doi.org/10.1016/i.gfs.2020.100365

Stuart, A.M., Nogues Palenzuela, A., Bernal, C.C., Ramal, A.F. and Horgan, F.G. (2014) Effects of fertiliser applications on survival and recruitment of the apple snail, Pomacea canaliculata (Lamarck). Crop Protection 64, 78-87. https://doi.org/10.1016/..cropro.2014.05.020

Suharto, H. (2002) Golden apple snail, Pomacea canaliculata (Lamarck) in Indonesia. In: Wada, T., Yusa, Y. and Joshi, R.C. (eds) Proceedings of the Meeting of the Special Working Group on the Golden Apple Snail (Pomacea spp.) at the Seventh International Congress on Medical and Applied Malacology. SEAMEO Regional Center for Graduate Study and Research in Agriculture, Los Baños, Laguna, Philippines, pp. 69-73.

Suzuki, Y., Miyamoto, K., Matsumura, M., Arimura, K. and Tubiano, F. (1999) Predacious natural enemies of the golden apple snail, Pomacea canaliculata juveniles in paddy fields. Kyushu Agricultural Research 61, 83.

Syamsul, R.B., Muhamad, R., Arfan, A.G. and Manjeri, G. (2016) Effectiveness of various botanical traps against apple snail, Pomacea maculata (Gastropoda: Ampullariidae) in a rice field. Pertanika Journal of Tropical Agricultural Science 39(2), 137-143.

Tadesse, T., Atnaf, M., Alemu, D., Tadesse, T. and Shiratori, K. (2019) Advances in Rice Research and Development in Ethiopia. Ethiopian Institute of Agricultural Research, Addis Ababa, 309 pp.

Tamburi, N.E. and Martín, P.R. (2011) Effects of food availability on reproductive output, offspring quality and reproductive efficiency in the apple snail Pomacea canaliculata. Biological Invasions 13, 2351-2360. https://doi.org/10.1007/s10530-011-0047-2

Tanzania Ministry of Agriculture (2009) National Rice Development Strategy. The United Republic of Tanzania Ministry of Agriculture, Food Security and Cooperatives, Dar Es Salaam, Tanzania, 32 pp.

Teo, S.S. (2001) Evaluation of different duck varieties for the control of the golden apple snail (Pomacea canaliculata) in transplanted and direct seeded rice. Crop Protection 20(7), 599-604. https://doi.org/10.1016/S0261-2194(01)00029-1

Teo, S.S. (2003) Damage potential of the golden apple snail Pomacea canaliculata (Lamarck) in irrigated rice and its control by cultural approaches. International Journal of Pest Management 49, 49-55. https://doi.org/10.1080/713867835. 
Teo, S.S. (2006) Evaluation of different species of fish for biological control of golden apple snail Pomacea canaliculata (Lamarck) in rice. Crop Protection 25(9), 1004-1012. https://doi.org/10.1016/i.cropro.2006.01.012

Thiengo, S.C. (1987) Observations on the morphology of Pomacea lineata (Spix, 1827) (Mollusca, Ampullariidae). Memórias do Instituto Oswaldo Cruz 82, 563-570. https://doi.org/10.1590/S0074$\underline{02761987000400015}$

Thiengo, S.C., Borda, C.E. and Araújo, J.L.B. (1993) On Pomacea canaliculata (Lamarck, 1822) (Mollusca; Pilidae: Ampullariidae). Memórias do Instituto Oswaldo Cruz 88, 67-71. https://doi.org/10.1590/S0074-02761993000100011

Tiecher, M.J., Seuffert, M.E., Burela, S. and Martín, P.R. (2017) Life table and demographic parameters of the neotropical apple snail Asolene platae (Caenogastropoda, Ampullariidae). American Malacological Bulletin 35, 119-125. https://doi.org/10.4003/006.035.0204

Tricarico, E., Junqueira, A.O.R. and Dudgeon, D. (2016) Alien species in aquatic environments: a selective comparison of coastal and inland waters in tropical and temperate latitudes: alien species in aquatic environments. Aquatic Conservation: Marine and Freshwater Ecosystems 26, 872-891. https://doi.org/10.1002/aqc.2711

Tsega, M., Alemu, D. and Kiyoshi, S. (2013) Socioeconomic Characteristics of Smallholder Rice Production in Ethiopia. Ethiopian Institute of Agricultural Research, Addis Ababa, 53 pp.

Turner, A.M., Turner, R.R. and Ray, S.R. (2007) Competition and intraguild egg predation among freshwater snails: re-examining the mechanism of interspecific interactions. Oikos 116, 18951903. https://doi.org/10.1111/j.0030-1299.2007.15883.x

Ueshima, E. and Yusa, Y. (2015) Antipredator behaviour in response to single or combined predator cues in the apple snail Pomacea canaliculata. Journal of Molluscan Studies 81, 51-57. https://doi.org/10.1093/mollus/eyu057

Uganda Bureau of Statistics (2020) Annual Agriculture Survey 2018. Uganda Bureau of Statistics (UBOS), Kampala, 348 pp.

US Bureau of Labor Statistics (2021) CPI Inflation Calculator. U.S. Bureau of Labor Statistics. Available at: https://www.bls.gov/data/inflation calculator.htm (accessed 11 March 2021).

Valverde, A.L., Silva-Souza, N., Marques, A.M. and Cantanhede, S.P. (2010) Atividade moluscicida de plantas: uma alternative profilática. Brazilian Journal of Pharmacognosy 20(2), 282-288.

van Leeuwen, C.H.A. and van der Velde, G. (2012) Prerequisites for flying snails: external transport potential of aquatic snails by waterbirds. Freshwater Science 31, 963-972.

https://doi.org/10.1899/12-023.1

van Leeuwen, C.H.A., van der Velde, G., van Groenendael, J.M. and Klaassen, M. (2012) Gut travellers: internal dispersal of aquatic organisms by waterfowl. Journal of Biogeography 39, 2031-2040. https://doi.org/10.1111/jbi.12004

van Oort, P.A.J., Saito, K., Tanaka, A., Amovin-Assagba, E., Van Bussel, L.G.J., et al. (2015) Assessment of rice self-sufficiency in 2025 in eight African countries. Global Food Security 5, 3949.

Vázquez-Silva, G., Castro-Barrera, T., Castro-Mejía, J. and Mendoza-Martínez, D. (2011) Los caracoles del género Pomacea (Perry, 1810) y su importancia ecológica y socioeconómica. ContactoS 81, 28-33.

Vega, I.A., Arribére, M.A., Almonacid, A.V., Ribeiro Guevara, S. and Castro-Vazquez, A. (2012) Apple snails and their endosymbionts bioconcentrate heavy metals and uranium from contaminated drinking water. Environmental Science and Pollution Research 19, 3307-3316.

https://doi.org/10.1007/s11356-012-0848-6 
Wada, T. (1997) Introduction of the apple snail Pomacea canaliculata and its impact on rice agriculture. In: Yano, E., Matsuno, K., Shiyomi, M. and Andow, D.A. (eds) International Workshop on Biological Invasions of Ecosystem by Pests and Beneficial Organisms. National Institute of Agro-Environmental Sciences, Tsukuba, Japan, pp. 143-151.

Wada, T. (2004) Strategies for controlling the apple snail Pomacea canaliculata (Lamarck) (Gastropoda: Ampullariidae) in Japanese direct-sown paddy fields. Japan Agricultural Research Quarterly 38, 75-80. https://doi.org/10.6090/jarq.38.75

Wada, T. (2006) Impact and control of introduced apple snail, Pomacea canaliculata (Lamarck), in Japan. In: Joshi, R.C. and Sebastian, L.S. (eds) Global Advances in Ecology and Management of Golden Apple Snails. Philippine Rice Research Institute, Nueva Ecija, Philippines, pp. 181-197.

Wada, T. and Matsukura, K. (2007) Seasonal changes in cold hardiness of the invasive freshwater apple snail, Pomacea canaliculata (Lamarck) (Gastropoda: Ampullariidae). Malacologia 49, 383392. https://doi.org/10.4002/0076-2997-49.2.383

Wada, T., Ichinose, K. and Higuchi, H. (1999) Effect of drainage on damage to direct-sown rice by the apple snail Pomacea canaliculata (Lamarck) (Gastropoda: Ampullariidae). Applied Entomology and Zoology 34, 365-370. https://doi.org/10.1303/aez.34.365

Wada, T., Joshi, R.C. and Yusa, Y. (2002) Experiences of Japanese rice farmers with apple snail, Pomacea canaliculata (Lamarck) for paddy weeding in transplanted rice: a video documentation. In: Wada, T., Yusa, Y. and Joshi, R.C. (eds) Proceedings of the Meeting of the Special Working Group on the Golden Apple Snail (Pomacea spp.) at the Seventh International Congress on Medical and Applied Malacology. SEAMEO Regional Center for Graduate Study and Research in Agriculture, Los Baños, Laguna, Philippines, 22 pp.

Wang, Q.-P., Lai, D.-H., Zhu, X.-Q., Chen, X.-G. and Lun, Z.-R. (2008) Human angiostrongyliasis. The Lancet Infectious Diseases 8(10), 621-630. https://doi.org/10.1016/S1473-3099(08)70229-9

Wang, Z., Tan, J., Tan, L., Liu, J. and Zhong, L. (2012) Control the egg hatchling process of Pomacea canaliculata (Lamarck) by water spraying and submersion. Acta Ecologica Sinica 32, 184-188. https://doi.org/10.1016/j.chnaes.2012.04.008

Wilson, R.T. and Lewis, I. (2005) The Rice Value Chain in Tanzania. A Report from the Southern Highlands Food Systems Programme. Food and Agriculture Organization of the United Nations, Rome, $111 \mathrm{pp}$.

Wong, P.K., Kwong, K.L. and Qiu, J.-W. (2009) Complex interactions among fish, snails and macrophytes: implications for biological control of an invasive snail. Biological Invasions 11, 2223-2232. https://doi.org/10.1007/s10530-008-9378-z

Wong, P.K., Liang, Y., Liu, N.Y. and Qiu, J.-W. (2010) Palatability of macrophytes to the invasive freshwater snail Pomacea canaliculata: differential effects of multiple plant traits: determinants of plant palatability. Freshwater Biology 55, 2023-2031. https://doi.org/10.1111/j.13652427.2010.02458.x

Wood, T.S., Anurakpongsatorn, P., Chaichana, R., Mahujchariyawong, J. and Satapanajaru, T. (2006) Heavy predation on freshwater bryozoans by the golden apple snail, Pomacea canaliculata Lamarck, 1822 (Ampullariidae). The Natural History Journal of Chulalongkorn University 6(1), 3136.

Wu, M. and Xie, Y. (2006) The golden apple snail (Pomacea canaliculata) in China. In: Joshi, R.C. and Sebastian, L.S. (eds) Global Advances in Ecology and Management of Golden Apple Snails. Philippine Rice Research Institute, Nueva Ecija, Philippines, pp. 285-298.

Wu, Z.P., Chen, K.L., Qing, Y.W., Zhang, Z.D., Zhang, H.B. and Li, P.L. (1995) Study on the outbreak and eradication of Ampullaria canaliculata Lamark in Sichuan. Plant Quarantine 9(5), 266-269. 
Xia, J., Yuan, Y., Xu, X., Wei, F., Li, G., et al. (2014) Evaluating the effect of a novel molluscicide in the endemic Schistosomiasis japonica area of China. International Journal of Environmental Research and Public Health 11, 10406-10418. https://doi.org/10.3390/ijerph111010406

Yahaya, H., Nordin, M., Muhamad Hisham, M.N. and Sivapragasam, A. (2006) Golden apple snails in Malaysia. In: Joshi, R.C. and Sebastian, L.S. (eds) Global Advances in Ecology and Management of Golden Apple Snails. Philippine Rice Research Institute, Nueva Ecija, Philippines, pp. 215230.

Yahaya, H., Nordin, M., Hisham, M.N.M. and Sivapragasam, A. (2017) Invasive apple snails in Malaysia. In: Joshi, R.C., Cowie, R.H. and Sebastian, L.S. (eds) Biology and management of invasive apple snails. 2nd edition. Philippine Rice Research Institute, Nueva Ecijia, Philippines, pp. 169-195.

Yamane, Y. (2019) Rice distribution in Kenya: the conditions of rice traders in the rice cultivation area around Lake Victoria. Agricultural Research \& Technology: Open Access Journal 19(4), 556099. https://doi.org/10.19080/ARTOAJ.2019.19.556099

Yang, P.-S., Chen, Y.-H., Lee, W.-C. and Chen, Y.-H. (2006) Golden apple snail management and prevention in Taiwan. In: Joshi, R.C. and Sebastian, L.S. (eds) Global Advances in Ecology and Management of Golden Apple Snails. Philippine Rice Research Institute, Nueva Ecija, Philippines, pp. 169-179.

Yang, T.B., Wu, Z.D. and Lun, Z.R. (2013) The apple snail Pomacea canaliculata, a novel vector of the rat lungworm, Angiostrongylus cantonensis: its introduction, spread, and control in China. Hawaii Journal of Medicine \& Public Health 72(6, suppl. 2), 23-25.

Yang, C.-P., Zhang, M., Lei, B., Gong, G., Yue, G., Chang, X., Sun, X.-F., Tian, Y. and Chen, H.-B. (2017) Active saponins from root of Pueraria peduncularis (Grah. ex Benth.) Benth. and their molluscicidal effects on Pomacea canaliculata. Pest Management Science 73(6), 1143-1147.

Yoshida, K., Hoshikawa, K., Wada, T. and Yusa, Y. (2009) Life cycle of the apple snail Pomacea canaliculata (Caenogastropoda: Ampullariidae) inhabiting Japanese paddy fields. Applied Entomology and Zoology 44, 465-474. https://doi.org/10.1303/aez.2009.465

Yoshie, H. and Yusa, Y. (2008) Effects of predation on the exotic freshwater snail Pomacea canaliculata (Caenogastropoda: Ampullariidae) by the indigenous turtle Chinemys reevesii (Testudines: Geoemydidae). Applied Entomology and Zoology 43, 475-482. https://doi.org/10.1303/aez.2008.475

Yusa, Y. (2001) Predation on eggs of the apple snail Pomacea canaliculata (Gastropoda: Ampullariidae) by the fire ant Solenopsis geminata. Journal of Molluscan Studies 67, 275-279. https://doi.org/10.1093/mollus/67.3.275

Yusa, Y. (2006) Predators of the introduced apple snail, Pomacea canaliculata (Gastropoda: Ampullariidae): their effectiveness and utilization in biological control. In: Joshi, R.C. and Sebastian, L.S. (eds) Global Advances in Ecology and Management of Golden Apple Snails. Philippine Rice Research Institute, Nueva Ecija, Philippines, pp. 345-361.

Yusa, Y. and Wada, T. (1999) Impact of the introduction of apple snails and their control in Japan. Naga: the ICLARM Quarterly 22(3), 9-13.

Yusa, Y. and Wada, T. (2002) Current status of the Pomacea canaliculata in Japan. In: Wada, T., Yusa, Y. and Joshi, R.C. (eds) Proceedings of the Meeting of the Special Working Group on the Golden Apple Snail (Pomacea spp.) at the Seventh International Congress on Medical and Applied Malacology. SEAMEO Regional Center for Graduate Study and Research in Agriculture, Los Baños, Laguna, Philippines, pp. 74-79.

Yusa, Y., Sugiura, N. and Ichinose, K. (2000) Predation on the apple snail, Pomacea canaliculata (Ampullariidae), by the Norwegian rat, in the field. Veliger 43, 349-353. 
Yusa, Y., Sugiura, N. and Wada, T. (2006) Predatory potential of freshwater animals on an invasive agricultural pest, the apple snail Pomacea canaliculata (Gastropoda: Ampullariidae), in Southern Japan. Biological Invasions 8, 137-147. https://doi.org/10.1007/s10530-004-1790-4

Zhou, W.C., Wu, Y.F. and Yang, J.Q. (2003) Viability of the Ampullaria snail in China. Fujian Journal of Agricultural Sciences 18(1), 25-28. 


\section{contact CABI}

\section{Africa}

Kenya

CABI, Canary Bird

673 Limuru Road, Muthaiga

PO Box 633-00621

Nairobi, Kenya

T: +254 (0)20 2271000/ 20

E: africa@cabi.org

\section{Ghana}

CABI, CSIR Campus

No. 6 Agostino Neto Road

Airport Residential Area

P. O. Box CT 8630, Cantonments

Accra, Ghana

T: +233 (0)302 797202

E: westafrica@cabi.org

Zambia

CABI, Southern Africa Centre

5834 Mwange Close

Kalundu

P.O. Box 37589

Lusaka, Zambia

T: +260967619665

E: westafrica@cabi.org

\section{Americas}

Brazil

CABI, UNESP-Fazenda Experimental Lageado, FEPAF (Escritorio da CABI)

Rua Dr. Jose Barbosa de Barros 1780

Fazenda Experimental Lageado

CEP:18.610-307

Botucatu, São Paulo, Brazil

T: + 5514-38826300

E: y.colmenarez@cabi.org

Trinidad \& Tobago

CABI, Gordon Street, Curepe

Trinidad and Tobago

T: +18686457628

E: caribbeanLA@cabi.org

USA

CABI, 745 Atlantic Avenue

8th Floor, Boston,

MA 02111, USA

T: +1 (617) 682-9015

E: cabi-nao@cabi.org

\section{Asia}

China

CABI, Beijing Representative Office

Internal Post Box 85

Chinese Academy of Agricultural Sciences

12 Zhongguancun Nandajie

Beijing 100081, China

T: +86 (0)10 82105692

E: china@cabi.org

\section{India}

CABI, 2nd Floor, CG Block,

NASC Complex, DP Shastri Marg

Opp. Todapur Village, PUSA

New Delhi - 110012, India

T: +91 (0)1125841906

E: cabi-india@cabi.org

Malaysia

CABI, PO Box 210,

43400 UPM Serdang

Selangor, Malaysia

T: +60 (0)3 89432921

E: cabisea@cabi.org

Pakistan

CABI, Opposite 1-A,

Data Gunj Baksh Road

Satellite Town, PO Box 8

Rawalpindi, Pakistan

T: +92 (0)519290132

E: sasia@cabi.org

\section{Europe}

Switzerland

CABI, Rue des Grillons 1

$\mathrm{CH}-2800$ Delémont, Switzerland

T: + 41 (0)32 4214870

E: europe-CH@cabi.org

UK

CABI, Nosworthy Way

Wallingford, Oxfordshire, OX10 8DE, UK T: +44 (0)1491832111

E: corporate@cabi.org

CABI, Bakeham Lane

Egham, Surrey, TW20 9TY, UK

T: + 44 (0)1491 829080

E: cabieurope-uk@cabi.org

E:microbialservices@cabi.org 